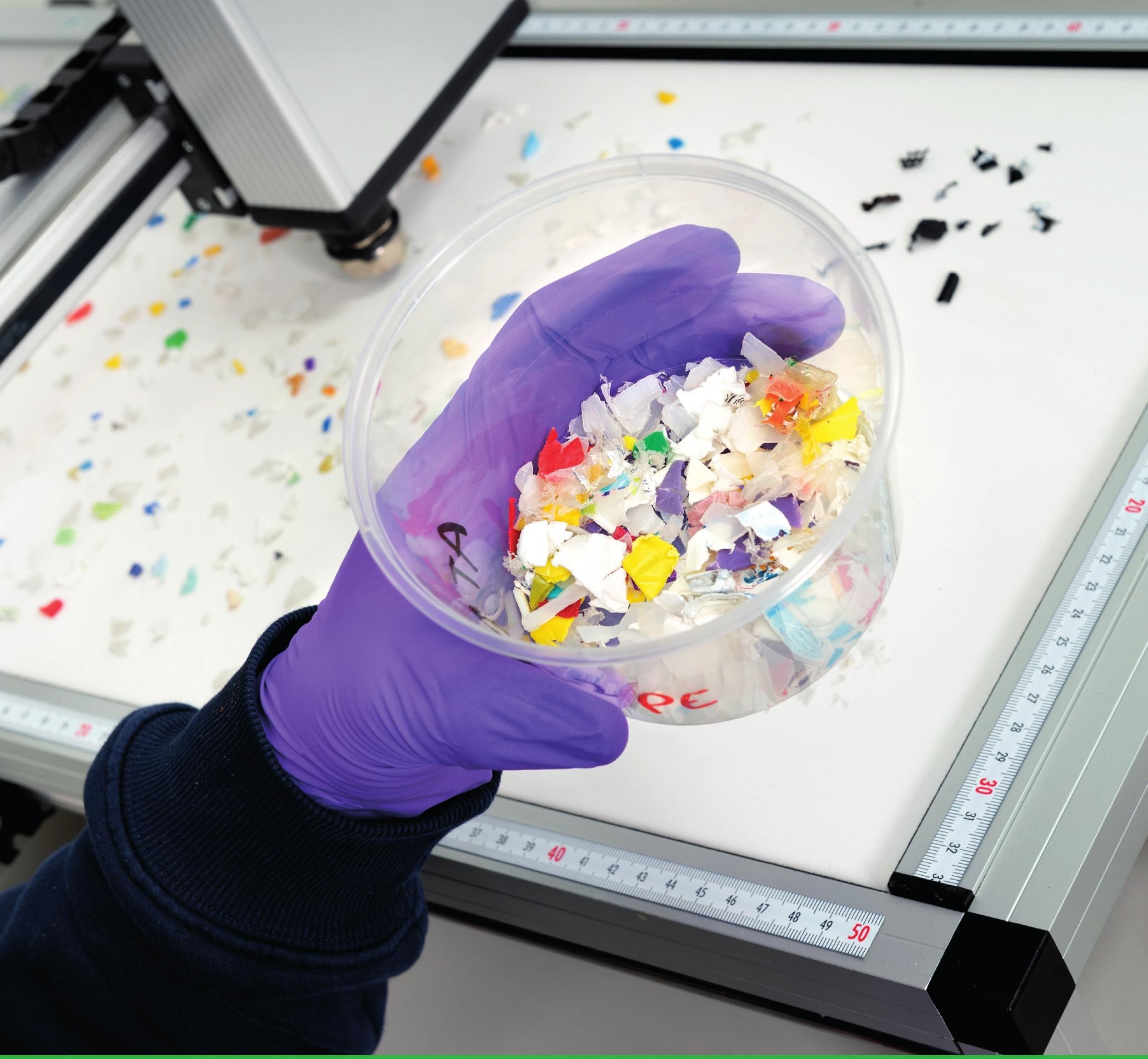

A first assessment of the impact of impurities in PP and PE recycled plastics

F. Alvarado Chacon, M.T. Brouwer, E.U. Thoden van Velzen, I.W. Smeding

WAGENINGEN

UNIVERSITY \& RESEARCH 



\section{A first assessment of the impact of impurities in PP and PE recycled plastics}

Authors: F. Alvarado Chacon, M.T. Brouwer, E.U. Thoden van Velzen, I.W. Smeding

Institute: Wageningen Food \& Biobased Research

This research project has been carried out by Wageningen Food \& Biobased Research commissioned by Nedvang and funded by Stichting Afvalfonds, in the context of Project "Standardisation quality of recycled plastics to enhance circular applications" (project number 62290733-01).

Wageningen Food \& Biobased Research

Wageningen, March 2020

Public

Report 2030

ISBN 978-94-6395-358-0 
Version: final

Reviewer: Wouter Post

Approved by: Arie van der Bent

Client: Nedvang

Sponsor: Stichting Afvalfonds

This report can be downloaded for free at https://doi.org/10.18174/518299 or at www.wur.eu/wfbr (under publications).

(C) 2019 Wageningen Food \& Biobased Research, institute within the legal entity Stichting Wageningen Research.

PO box 17, 6700 AA Wageningen, The Netherlands, T + 31 (0)317 4800 84, E info.wfbr@wur.nl, www.wur.eu/wfbr. Wageningen Food \& Biobased Research is part of Wageningen University \& Research.

All rights reserved. No part of this publication may be reproduced, stored in a retrieval system of any nature, or transmitted, in any form or by any means, electronic, mechanical, photocopying, recording or otherwise, without the prior permission of the publisher. The publisher does not accept any liability for inaccuracies in this report. 


\section{Contents}

1 Introduction

$\begin{array}{lll}2.1 & \text { Task 1: Perceptions of the plastic recycling industry } & 20\end{array}$

$\begin{array}{lll}2.2 & \text { Task 2: Perceptions of the packaging industry } & 20\end{array}$

$\begin{array}{lll}2.3 & \text { Task 3: Analysis of current quality of recycled PP and PE } & 20\end{array}$

2.3.1 Analysis of the polymeric composition of flakes $\quad 21$

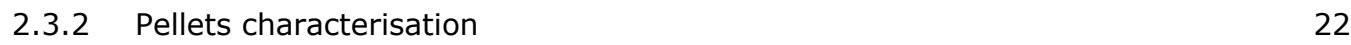

2.3.3 Model analysis on origin of impurities $\quad 23$

$\begin{array}{lll}2.4 & \text { Task 4: Impact of impurities in PP and PE recycled plastics } & 24\end{array}$

2.4.1 From sorted product to washed milled goods $\quad 25$

2.4.2 Matrix definition and preparation of samples with impurities 26

$\begin{array}{lll}2.4 .3 & \text { rPP processing and analysis } & 29\end{array}$

$\begin{array}{lll}2.4 .4 & \text { rPE processing and analysis } & 32\end{array}$

$3 \quad$ Perceptions of the plastic recycling industry $\quad 34$

$\begin{array}{lll}3.1 & \text { Current practices } & 34\end{array}$

$\begin{array}{lll}3.1 .1 & \text { Feedstock } & 34\end{array}$

$\begin{array}{lll}3.1 .2 & \text { Processes } & 35\end{array}$

$\begin{array}{lll}3.1 .3 & \text { Products } & 35\end{array}$

$\begin{array}{lll}3.2 & \text { Business barriers } & 35\end{array}$

3.2.1 Avoid potential risks $\quad 36$

$\begin{array}{lll}3.2 .2 & \text { Optical properties } & 36\end{array}$

$\begin{array}{lll}3.2 .3 \text { Odour } & 36\end{array}$

$\begin{array}{lll}3.2 .4 & \text { Legislation } & 36\end{array}$

3.2.5 General business issues $\quad 36$

$4 \quad$ Perceptions of the packaging industry $\quad 38$

$\begin{array}{lll}4.1 & \text { Motivation } & 38\end{array}$

$\begin{array}{lll}4.2 & \text { Barriers } & 38\end{array}$

4.2.1 Maturity of the recycling industry 38

$\begin{array}{lll}4.2 .2 & \text { Quality issues } & 39\end{array}$

$\begin{array}{lll}4.2 .3 & \text { Processability } & 40\end{array}$

$\begin{array}{lll}\text { 4.2.4 } & \text { Better safe than sorry } & 40\end{array}$

$5 \quad$ Analysis of current quality of recycled PP and PE $\quad 41$

$\begin{array}{lll}5.1 & \text { Flakes } & 41\end{array}$

$\begin{array}{lll}5.1 .1 & \text { Analysis of rPP flakes } & 41\end{array}$

5.1.2 Analysis of rPE flakes $\quad 42$

5.1.3 Model analysis on origin of impurities $\quad 43$

$\begin{array}{lll}5.2 & \text { Pellets } & 44\end{array}$

$\begin{array}{lll}\text { 5.2.1 Analysis of rPP pellets } & 44\end{array}$

$\begin{array}{lll}\text { 5.2.2 } & \text { Analysis of rPE pellets } & 47\end{array}$

$6 \quad$ Impact of impurities in PP and PE recycled plastics 49

6.1 Sample preparation: from sorted product to washed milled goods 49

6.1.1 Composition of the sorted products and its representativeness $\quad 49$

$\begin{array}{ll}\text { 6.1.2 Mechanical recycling of sorted products } & 50\end{array}$

$\begin{array}{lll}6.2 & \text { Processing and analysis of rPP material } & 51\end{array}$

$\begin{array}{lll}6.2 .1 & \text { rPP processing } & 51\end{array}$ 
6.2.2 Polymer melt flow results

6.2.3 Mechanical analysis $\quad 54$

6.2.4 Physical, chemical and thermal analysis $\quad 55$

$\begin{array}{lll}6.2 .5 & \text { Colour characterization } & 57\end{array}$

$\begin{array}{lll}6.3 & \text { Processing and analysis of rPE material } & 58\end{array}$

$\begin{array}{lll}6.3 .1 & \text { rPE processing } & 58\end{array}$

$\begin{array}{lll}6.3 .2 & \text { Polymer melt flow results } & 60\end{array}$

6.3.3 Mechanical analysis $\quad 60$

$\begin{array}{lll}\text { 6.3.4 Physical, chemical and thermal analysis } & 61\end{array}$

$\begin{array}{lll}6.3 .5 & \text { Colour characterization } & 63\end{array}$

7 Discussion $\quad 64$

$\begin{array}{lll}7.1 & \text { Comparison of the results with scientific literature } & 64\end{array}$

$\begin{array}{lll}7.1 .1 & \text { Recycled materials as blends } & 64\end{array}$

$\begin{array}{lll}7.1 .2 & \text { Processing } & 66\end{array}$

$\begin{array}{lll}7.2 & \text { Analysing recycled plastics } & 66\end{array}$

7.2.1 Polymeric composition of recycled plastics $\quad 66$

$\begin{array}{lll}7.2 .2 & \text { Melt flow properties } & 67\end{array}$

$\begin{array}{lll}7.3 & \text { Properties of recycled PE and PP pellets } & 68\end{array}$

$\begin{array}{lll}\text { 7.3.1 Commercial vs. high purity recycled plastics } & 68\end{array}$

7.3.2 Factors influencing processing and properties of rPE and rPP 69

$\begin{array}{lll}7.4 & \text { Towards more circularity } & 69\end{array}$

7.4.1 Stricter quality control within the current recycling system $\quad 70$

7.4.2 Enhancing applicability of existing recycled plastics 70

$\begin{array}{ll}\text { 7.4.3 A new system based on advanced sorting technologies } & 71\end{array}$

$8 \quad$ Conclusion and recommendations $\quad 72$

$\begin{array}{lr}\text { Appendix A } & 77\end{array}$

$\begin{array}{lr}\text { Appendix B } & 78\end{array}$

$\begin{array}{lr}\text { Appendix C } & 79\end{array}$

$\begin{array}{lr}\text { Appendix D } & 86\end{array}$

$\begin{array}{lr}\text { Appendix E } & 89\end{array}$

$\begin{array}{lr}\text { Appendix F } & 92\end{array}$

$\begin{array}{lr}\text { Appendix G } & 94\end{array}$ 


\section{Summary}

\section{Introduction}

The recycling of Dutch post-consumer plastic packaging waste yields five types of recycled plastics recycled PET from bottles (rPET), recycled PE (rPE), recycled PP (rPP), recycled film (rfilm) and Mixed plastics. For two rigid recycled plastics (PP and PE) substantial improvements have been achieved over the past years: more and more of these recycled plastics are used in circular applications such a non-beverage bottles, crates, paint pots, etc. However, the required properties of these recycled plastics to enable circular applications have not been thoroughly described, nor has the influence of impurities on the properties systematically been studied, yet. Filling this knowledge gap would facilitate more circular applications and make a meaningful contribution in our shared ambition to achieve a more circular economy for plastic packages. Nedvang has commissioned Wageningen Food \& Biobased Research to assess of the impact of impurities in PP and PE recycled plastics (rPP and rPE), made from Dutch post-consumer plastic packaging waste. The research is limited to those impurities that are likely to occur regularly in recycled PE and PP. The studied properties of the recycled plastics are limited to those that are relevant for the polymers and their applications.

The research described in this report had multiple objectives:

- $\quad$ Provide a better understanding of the impurities that occur regularly in recycled PE and recycled $\mathrm{PP}$, both with regard to different materials and polymers.

- $\quad$ Reach a better understanding of the critical properties of recycled PE and PP to enable circular applications.

- Improve the understanding of how impurities affect the applicability of the recycled plastics, by systematically studying the impact of impurities on the properties of recycled plastics.

- Understand the opinions of two sets of stakeholders in relation to the quality of recycled plastics and their potential use in packages; the recycling industry as producer and the fast moving consumer goods industry as customer for the recycled PE and PP.

This is valuable input information in discussions on the future of recycling systems for post-consumer plastics. For example, this knowledge could be used as a base for new, future quality standards and specifications.

\section{Perceptions of the plastic recycling industry}

Interviews were conducted with one German and four Dutch recycling industries, all with a focus on processing Dutch sorted PE and PP products. These five companies process the main volume of Dutch sorted PE and PP products.

\section{Current practices}

A minority of the interviewed companies exclusively use sorted post-consumer packaging waste as feedstock. Most of the companies use mixtures of post-consumer sorted plastics, post-industrial sorted plastics and sorted municipal plastic waste as feedstock. The quality of the feedstock is a major concern for all recycling companies. Recycling companies have different opinions on impurities in the feedstock. Impurities that were named as challenging by several companies are for example top-seal films for trays, glue residues and silicone rubber objects. Furthermore, recycled PP always contains PE that originates both from sorting mistakes and from packaging components; in case the PE share exceeds $20 \%$, the processing of rPP becomes more difficult according to the interviewed companies. In recycled $\mathrm{PE}$ the most challenging impurities are for example paper and wood, silicon kit tubes and too high levels of PP (roughly above 15\%).

Most recycling companies have a standard mechanical recycling process in place, but there are different variations. The most prominent difference in process that has effect on the final product quality is flake-sorting. 
Most companies trade compounds with recycled plastics, some pellets of recycled plastic and some even finished plastic objects made from recycled plastic. For rPE these are mainly extrusion products such as non-food bottles and buckets. For rPP these are mainly injection moulded products like flower pots, waste containers and garden furniture. The vast majority of the products sold have a recycled content of $100 \%$.

\section{Business barriers}

For the majority of the recycling companies it is a continuous challenge to sell their products. Barriers which they experience are in general not technical, but relate to: avoidance of potential risks (in procurement specifications), optical properties (colour/gloss), odour, legislation (i.e. REACH) or other general business issues (i.e. relatively low prices of virgin plastics).

\section{Perceptions of the packaging industry}

Five representatives from the packaging industry were interviewed; it was a heterogenous group in size and type. Most of the companies are current users of recycled material, one of them is a nearfuture user.

\section{Motivation}

The prime motivation of Fast Moving Consumer Goods (FMCG) manufacturers to use post-consumer recycled $\mathrm{PE}$ and $\mathrm{PP}$ in their packages is to reduce the environmental impact of their productpackaging-combinations. For each product-packaging combination the options are typically evaluated for technical feasibility, costs, expected environmental impact and marketing impact. Depending on the packaging policies of the company the most suited option is selected.

\section{Barriers}

The users experience multiple barriers when using rPE and rPP recycled content in their packages. Most barriers were named by multiple companies and are clearly shared experiences. The recycling industry is much smaller in size than the virgin plastic industry and is less mature. This implies that less brands and types are available and only limited grades of recycled plastics are available. Since larger enterprises typically need kilotons of plastics even for their smallest products, their problem is procuring these different, highly specific, qualities of recycled plastics in sufficiently large amounts. Additionally there are different quality issues. The main quality issue is food safety; currently rPE and rPP are not available for food applications. This has also secondary effects. As many packaging markets, like personal care, don't have regulations, some companies require food-grade material as well. Another issue is that several plastic converters produce packages for both food and non-food markets. As they have to comply to Hazard Analysis and Critical Control Point (HACCP) regulations, they are often not allowed to work with non-food-grade recycled plastics. Besides food safety, other quality issues that are regarded as a barrier for the use of recycled plastics are related to odour, colour and quality variations (only small tolerances are allowed). A next barrier is that recycled PE and PP are made of mixtures of grades and contain impurities, which can influence the processability of the materials.

\section{Analysis of current quality of recycled PP and PE}

Six recycling companies provided samples of their flakes and/or pellets for analysis in this project.

\section{Flakes}

The polymeric composition of flakes was determined with a NIR-based flake sorting machine. Industrially produced post-consumer PP flakes are composed of mostly PP (92-94\%) and some PE (3-4\%) and usually sub-percent amounts of minor impurities. Some of the minor impurities are always present at sub-percent levels (PET, PS, PVC, Aluminium) and other impurities are sporadically present (PMMA, PC, wood, paper, textile). 
The industrially recycled post-consumer PE flakes consist of $90-95 \% \mathrm{PE}, 2-7 \% \mathrm{PP}, 1-4 \%$ black and several sub-percent impurities. Of these, most were polymeric impurities. PS was present in all samples at concentrations of $0.03-0.3 \%$. PET and PA were present in more than half of the samples in concentrations of $0.004-0.2 \%$ and $0.1-0.2 \%$, respectively.

The origin of impurities in recycled PE and PP samples was tracked using an already published material-flow analysis model of the Dutch recycling chain of post-consumer plastic packaging waste in 2014 and 2017 [Brouwer, et al. 2018, Brouwer, et al. 2019]. The model shows that in the PE washed milled goods roughly $80 \%$ of the polymeric impurities originate from the PE packages itself, and thus roughly $20 \%$ are a result of other, faulty sorted products. In the PP washed milled goods this is reversed: $15-20 \%$ originates from the PP packages, and thus $80-85 \%$ originates from sorting mistakes.

\section{Pellets}

Pellets were analysed with different measurements:

- Polymer flow measurements: Melt Flow Index (MFI) and rotational rheometry (viscosity).

- Chemical and thermal analysis: Differential Scanning Calorimetry (DSC) was used to study the thermal properties of the received samples. Melting temperatures, degree of crystallinity and purity of the samples can be derived from these measurements. Furthermore, Infrared analysis (FTIR) was used to study chemical composition of the samples and to verify the presence of impurities. In some of the samples also Thermo Gravimetric Analysis (TGA) was done.

- Colour characterization

The melt flow index measured for both the commercial rPP and rPE products were found to be the same as the MFI values specified in the data sheets provided by the companies. There is substantial variation in MFI of rPP products on the market. These values indicate that the rPP's are suitable for injection moulding and the rPE's for extrusion processing. Thermal analysis and Infrared spectroscopy confirm that all rPP samples contain PE as impurity and vice versa.

\section{Impact of impurities in PP and PE recycled plastics}

\section{Sample preparation: from sorted product to washed milled goods}

To analyse the impact of impurities in the recycled PP and PE material, as a first step a sample of washed milled goods of both materials was prepared with high polymeric purity at object level. As starting material, sorted bales of PP and PE from a large sorting facility in the Netherlands were used. The composition of the sorted product which was used as input for the project was comparable to the average composition of Dutch sorted products.

In the laboratory the materials were sorted and only bodies, flasks and other rigid packaging of the targeted material were selected. To achieve a high polymer purity, all other materials were manually removed: caps and labels of non-targeted materials, multi-layer packages, packages with much product residue and packages with in-mould-labels.

The selected PP and PE objects were (separately) mechanically recycled according a standard recycling process. This yielded high polymeric purity washed milled goods of both materials. The mechanical recycling yields for both the PP flakes and the PE flakes was slightly higher than those previously reported for sorted PP and PE, respectively. This is likely caused by the fact that the feedstocks used in this study only contained 3 or 2 types of targeted packaging bodies and no sorting mistakes. The resulting flakes have polymeric purity levels exceeding $99.5 \%$, which is extremely high compared to industrial reality.

As a next step different known impurities have been added to the clean rPP and rPE flakes, to investigate the effect of the specific impurities on processing parameters and various material properties. Definition of the samples/impurities was done based on the interviews and analysis of the commercially available material, to make sure they are realistic and relevant. Figure S. 1 shows the description of the samples and the analyses which were performed for rPP. Figure S. 2 shows the same information for rPE. 


\begin{tabular}{|c|c|c|c|c|c|c|c|c|c|c|}
\hline Description & $\%$ & $\begin{array}{l}\text { MFI } \\
\text { (pellets) }\end{array}$ & $\begin{array}{l}\text { Spiral flow } \\
\text { (pellets) }\end{array}$ & $\begin{array}{l}\text { Charpy } \\
\text { Impact } \\
\text { (test } \\
\text { bars) } \\
\end{array}$ & $\begin{array}{l}\begin{array}{l}\text { Density } \\
\text { (test } \\
\text { bars) }\end{array} \\
\end{array}$ & $\begin{array}{l}\text { Colour } \\
\text { (test } \\
\text { bars) }\end{array}$ & \begin{tabular}{|l} 
DSC \\
(pellets)
\end{tabular} & $\begin{array}{l}\text { DMTA } \\
\text { (test } \\
\text { bars) }\end{array}$ & \begin{tabular}{|l} 
FT-IR \\
(pellets)
\end{tabular} & $\begin{array}{l}\text { Viscosity } \\
\text { (compresse } \\
\text { d pellets) } \\
\end{array}$ \\
\hline \multirow[t]{2}{*}{$\begin{array}{l}\text { Reference, } \\
100 \% \text { rPP }\end{array}$} & $0 \%$ & $V$ & $V$ & $\checkmark$ & $V$ & $\checkmark$ & $V$ & $\checkmark$ & $V$ & $\checkmark$ \\
\hline & $2 \%$ & $V$ & $\checkmark$ & $\checkmark$ & $V$ & $V$ & $V$ & $\checkmark$ & $\checkmark$ & $V$ \\
\hline \multirow[t]{2}{*}{ HDPE } & $5 \%$ & $\checkmark$ & $V$ & $\checkmark$ & $\checkmark$ & $V$ & $V$ & $\checkmark$ & $\checkmark$ & $\checkmark$ \\
\hline & $10 \%$ & $V$ & $V$ & $\checkmark$ & $\checkmark$ & $\checkmark$ & $V$ & $\checkmark$ & $V$ & $\checkmark$ \\
\hline LDPE & $2 \%$ & $V$ & $\checkmark$ & $\checkmark$ & $\checkmark$ & $V$ & $V$ & $\checkmark$ & $V$ & $V$ \\
\hline PET & $0.5 \%$ & $\checkmark$ & $\checkmark$ & $\checkmark$ & $V$ & $\checkmark$ & $V$ & $\checkmark$ & $V$ & $\checkmark$ \\
\hline PS & $0.5 \%$ & $\checkmark$ & $\checkmark$ & $\checkmark$ & $\checkmark$ & $\checkmark$ & $\checkmark$ & $\checkmark$ & $\checkmark$ & $\checkmark$ \\
\hline PVC & $0.5 \%$ & $\checkmark$ & $\checkmark$ & $\checkmark$ & $\checkmark$ & $\checkmark$ & $\checkmark$ & $\checkmark$ & $\checkmark$ & $\checkmark$ \\
\hline PP film & $3.5 \%$ & $\checkmark$ & $\checkmark$ & $\checkmark$ & $\checkmark$ & $\checkmark$ & $\checkmark$ & $\checkmark$ & $\checkmark$ & $V$ \\
\hline Aluminium & $0.5 \%$ & $\checkmark$ & $\checkmark$ & $\checkmark$ & $\checkmark$ & $V$ & $\checkmark$ & $V$ & $\checkmark$ & $\checkmark$ \\
\hline $\begin{array}{l}\text { In mould labels } \\
\text { (packages) }\end{array}$ & $50 \%$ & $\checkmark$ & $\checkmark$ & $\checkmark$ & $\checkmark$ & $\checkmark$ & $\checkmark$ & $\checkmark$ & $\checkmark$ & $\checkmark$ \\
\hline In mould labels & $5 \%$ & $\checkmark$ & $\checkmark$ & $\checkmark$ & $\checkmark$ & $\checkmark$ & $\checkmark$ & $\checkmark$ & $\checkmark$ & $\checkmark$ \\
\hline
\end{tabular}

Figure S. 1 rPP matrix indicating the sample variations (rows) vs the analysis methods (columns) used in this project

\begin{tabular}{|c|c|c|c|c|c|c|c|c|c|c|}
\hline Description & $\%$ & $\begin{array}{l}\text { MFI } \\
\text { (pellets) }\end{array}$ & $\begin{array}{l}\text { Viscosity } \\
\text { (compress } \\
\text { ed } \\
\text { moulded } \\
\text { samples) }\end{array}$ & $\begin{array}{l}\text { Charpy } \\
\text { impact } \\
\text { (test } \\
\text { bars) } \\
\end{array}$ & $\begin{array}{l}\text { Falling } \\
\text { dart } \\
\text { (extruded } \\
\text { sheet) }\end{array}$ & $\begin{array}{l}\text { Tensile } \\
\text { strength } \\
\text { (extruded } \\
\text { sheet) }\end{array}$ & $\begin{array}{l}\text { Density } \\
\text { (test } \\
\text { bars) }\end{array}$ & $\begin{array}{l}\text { Colour } \\
\text { (test } \\
\text { bars) }\end{array}$ & $\begin{array}{l}\text { DSC }+ \\
\text { crystallisa } \\
\text { tion } \\
\text { (pellets) }\end{array}$ & \begin{tabular}{|l} 
FT-IR \\
(pellets)
\end{tabular} \\
\hline \multirow[t]{2}{*}{$\begin{array}{l}\text { Reference, } \\
100 \% \text { rPE }\end{array}$} & $0 \%$ & $\checkmark$ & $\checkmark$ & $\checkmark$ & $\checkmark$ & $\checkmark$ & $\checkmark$ & $\checkmark$ & $V$ & $V$ \\
\hline & $2 \%$ & $V$ & $V$ & $V$ & $V$ & $V$ & $\checkmark$ & $V$ & $V$ & $V$ \\
\hline \multirow[t]{2}{*}{ PP } & $5 \%$ & $V$ & $V$ & $V$ & $V$ & $V$ & $V$ & $V$ & $V$ & $V$ \\
\hline & $10 \%$ & $V$ & $V$ & $V$ & $V$ & $V$ & $V$ & $V$ & $V$ & $V$ \\
\hline \multirow[b]{2}{*}{ LDPE } & $2 \%$ & $V$ & $V$ & $V$ & $V$ & $V$ & $V$ & $V$ & $V$ & $V$ \\
\hline & $5 \%$ & $V$ & $V$ & $V$ & $V$ & $V$ & $V$ & $V$ & $V$ & $V$ \\
\hline PET & $0.5 \%$ & $V$ & $V$ & $V$ & $V$ & $V$ & $V$ & $V$ & $\checkmark$ & $\checkmark$ \\
\hline PS & $0.5 \%$ & $V$ & $V$ & $V$ & $V$ & $V$ & $V$ & $V$ & $V$ & $V$ \\
\hline PVC & $0.5 \%$ & $V$ & $V$ & $V$ & $V$ & $V$ & $V$ & $V$ & $V$ & $V$ \\
\hline
\end{tabular}

Figure S. 2 rPE matrix indicating the sample variations (rows) vs the analysis methods (columns) used in this project

Processing and analysis of rPP material

Since PP is mainly used in injection moulding applications, it was decided to focus the analysis of the samples on properties relevant for the processing and characterization of injection moulded products. The rPP samples were first fed into an extruder, and then injection moulded. Both processing steps were carefully monitored to investigate the impact of the different impurities. The samples to which PET and metallised film were added are relatively difficult to process in an extruder with a filtration system like the one used in this project. Small aluminium and silicon particles were found in all of the filters, also PET and nylon fibers, most likely residues of packaging components. All studied materials could be injection moulded in relatively short times, comparable to the virgin references.

On the samples different measurements were applied: polymer flow measurements, mechanical analysis and physical, chemical and thermal analyses, as specified in Figure S. 1. The MFI is a crucial technical parameter in technical datasheets to assess the applicability of a given polymer. MFI values of the prepared samples are shown in Figure S. 3. It can be seen that HDPE and LDPE even in amounts of $2 \%$ decrease the MFI of the rPP materials. This is also true for most of the other added impurities but the effect is smaller. Samples where $50 \%$ of the bodies are replaced by bodies with in-mould labels (50IML) show a reversed behaviour, MFI increases compared to $100 \%$ rPP. Similar flow performance is observed in the spiral flow measurement. 


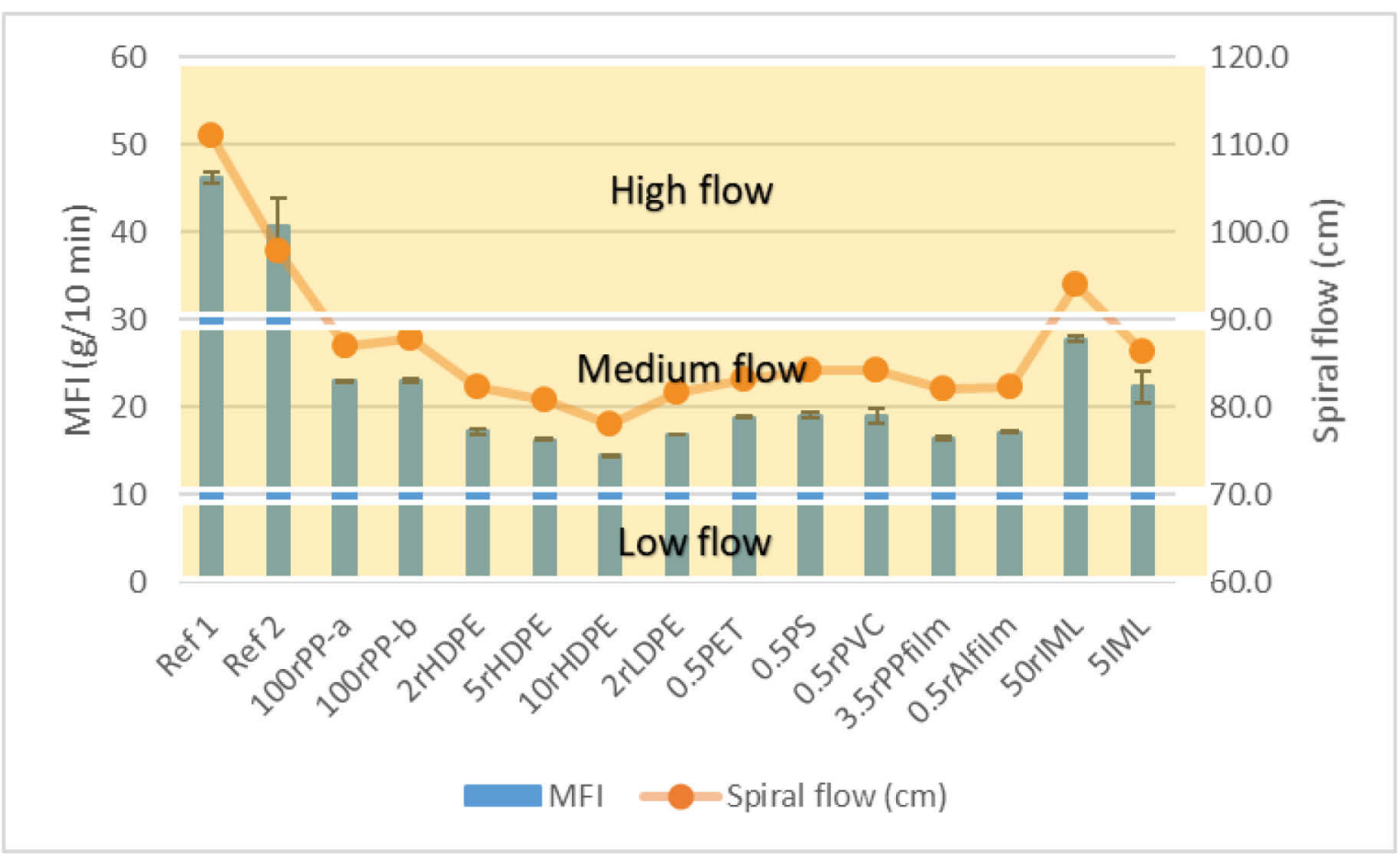

\section{Figure S.3 Flow properties MFI and spiral flow at $230^{\circ} \mathrm{C}$ of the studied rPP with different impurities compared to two high flow reference materials. Regions of high, medium and low flow are based on typical PP MFI values}

The impact strength of the $100 \%$ rPP sample (without added impurities) is comparable to one of the two virgin materials. Adding different percentages of HDPE and LDPE slightly increases the impact strength of the samples. Also, the impact results indicate that processing at elevated temperatures (sample 0.5PET-HT) negatively affects the mechanical properties.

DMTA confirms what is observed in other measurements, the largest differences are observed between the samples made of virgin materials and the samples containing recycled PP. rPP samples form a compact group with small variations while the difference relative to the virgin materials is large.

Recycled samples usually have a darker colour compared to virgin materials. Colour is influenced by the colour/ink of the collected packaging, therefore it is usually darker and with more colour tones than virgin materials which are white or transparent. When adding impurities, large effects can be observed in colour with respect to the reference $100 \% \mathrm{rPP}$. These differences cannot directly be attributed to the colour of added impurities, except in the case of in mould labels. Polymers as PET are badly miscible with PP, therefore even a small amount largely influences the colour. Also, temperature of the process changes the colour, this is visible in the 0.5PET-HT sample.

\section{Analysis of rPE material}

$\mathrm{PE}$ is mainly used in extrusion applications, and therefore the analysis focuses on the properties relevant for the processing and characterization of extruded products. After extrusion, sheets were extruded and additionally impact bars were injection moulded.

Most particles found on the filters after extrusion of rPE are different than those on melt filters after extrusion of rPP, the only exception being aluminium, which was found on both sets of melt filters. White silicon rubber pieces are most probably related to product residues of sealant cartridges or packaging components like anti-leakage valves. In spite of the impurities present in the $100 \% \mathrm{rPE}$ material and the added impurities, all produced rPE samples could be sheet extruded and injection moulded. Injection moulding times were however extremely long for the samples containing LDPE and PET.

The flow of PE was only affected by the addition of large amounts of PP, more than 5\%. The other added impurities did not significantly affect the MFI of rPE. This is also observed in the viscosity curves. 
PE types on the market are usually designed to achieve certain impact strength properties making them suitable for specific applications such as blow moulded bottles. Blow moulding applications require low MFI values and very high impact values. Impact resistance of all rPE samples was lower than the virgin reference, however there are applications in the market where this value would be sufficient. The degree of crystallinity that can be achieved with all rPE samples is lower than what can be achieved with the virgin reference, this might influence the final properties of the packaging product.

Samples containing post-consumer rPE are non-white since they were not colour-sorted. The largest colour differences when comparing the samples with impurities to the $100 \%$ rPE samples are observed for the smallest amount of impurities: $0.5 \%$ PET, PS and PVC.

\section{Discussion}

The scientific literature on the nature and properties of recycled plastics is not abundant. The most relevant technical insights are shortly introduced and compared with the results of this project. On top of the current knowledge from literature, this study has delivered new insights in the properties of recycled plastics. This study suggests that the processing and properties of recycled PE and PP are influenced by three factors:

1) Polymeric composition: blends of different polymer grades of the same polymer type.

2) Presence of impurities: relates both to the presence of polymeric contaminations and also to other materials.

3) Presence of additives.

This explains that recycled PP and PE - even if it has a high polymeric purity - always will have different properties compared to virgin material. Post-consumer recycled plastics are in their very nature a mixture of different tailor-made grades with consequently average properties. This situation is - besides legal and business barriers - an important reason for the current mismatch in supply and demand of recycled material. To overcome this challenging situation and achieve a higher level of circularity for PE and PP, several pathways are possible.

\section{Conclusion and recommendations}

First of all, design-for-recycling of packaging in combination with better compliance to existing specifications of the sorted products will reduce the amount of impurities present in the washed milled goods and consequently in the pellets. Moreover, the introduction of quality specifications on intermediate products such as washed milled goods could also enhance the quality of the produced pellets. This study can be used as a first exploration. However, to create formal specifications, more in-depth research is needed.

A second route is to enhance the applicability of existing recycled plastics by improving processing and entering new application fields. In a follow-up project additional measurement methods would need to be added to widen the scope of applicability. As alternative, the recycled material can be made more suitable for a specific application by using additives, adjusting processing parameters and/or redesign the final product. This is called design-from-recycling and needs involvement of all stakeholders in the chain.

The most extensive pathway would be a new system based on advanced sorting technologies. Ideas are for example to sort on different grades or to use marking technology to enable food-safe applications for rPP and rPE.

Summarizing, there are multiple pathways to improve the circularity of PE and PP. Regardless which route(s) will be followed, active participation of all stakeholders is needed, including the EU and national governments to set out a policy in one or more of these directions. 


\section{Samenvatting}

\section{Inleiding}

De recycling van Nederlands huishoudelijk kunststof verpakkingsafval levert vijf soorten gerecyclede kunststoffen op: uit flessen afkomstig gerecycled PET (rPET), gerecycled PE (rPE), gerecycled PP (rPP), gerecycled folie (rFilm) en Mix kunststoffen. Voor twee gerecyclede vormvaste kunststoffen (PP en PE) zijn aanzienlijke verbeteringen bereikt in de afgelopen jaren: steeds meer van deze gerecyclede kunststoffen worden gebruikt in circulaire toepassingen zoals flessen (niet voor drank), kratten, verfemmers, etc. Echter, tot nu toe zijn de eigenschappen, vereist voor circulaire toepassing van deze gerecyclede kunststoffen, nog niet tot in detail bekend. Daarnaast is ook nog niet eerder systematisch onderzocht welke invloed onzuiverheden in het recyclaat hebben op die eigenschappen. Kennis hierover kan meer circulaire toepassingen mogelijk maken en zal een zinvolle bijdrage zijn in onze gedeelde ambitie om een meer circulaire economie voor kunststof verpakkingen mogelijk te maken. Nedvang heeft Wageningen Food \& Biobased Research gevraagd om de invloed van onzuiverheden in PP en PE recyclaat (rPP en rPE), afkomstig van Nederlands huishoudelijk kunststof verpakkingsafval te onderzoeken. Het onderzoek is toegespitst op de onzuiverheden die daadwerkelijk regelmatig voorkomen in PE en PP recyclaat. De onderzochte eigenschappen van kunststoffen zijn gelimiteerd tot de eigenschappen die relevant zijn voor de polymeren en hun toepassingen.

Het onderzoek dat wordt beschreven in dit rapport had meerdere doelstellingen:

- $\quad$ Beter inzicht geven in de polymere en overige onzuiverheden die vaak voorkomen in gerecycled PE en PP.

- De kritische eigenschappen van gerecycled PE en PP beter begrijpen, om circulaire toepassingen mogelijk te maken.

- Meer inzicht verwerven over hoe onzuiverheden de toepasbaarheid van gerecyclede kunststoffen beïnvloeden, door systematisch het effect van onzuiverheden op de eigenschappen van recyclaat te onderzoeken.

- Diepgaand inzicht krijgen in de meningen van twee groepen stakeholders met betrekking tot de kwaliteit van gerecycled kunststof en hun mogelijke toepassing in verpakkingen; de recycling industrie als producent en het verpakkend bedrijfsleven als klant voor PE en PP recyclaat.

Dit is waardevolle informatie voor discussies over de toekomst van recycling systemen voor huishoudelijk kunststofverpakkingsafval. Deze kennis kan bijvoorbeeld gebruikt worden als basis voor nieuwe, toekomstige kwaliteitsstandaarden en specificaties.

\section{Inzichten van de kunststof recycling industrie}

Er zijn interviews afgenomen met een Duitse en vier Nederlandse recycling bedrijven, allemaal met een focus op het verwerken van Nederlands PE en PP sorteerproducten. Deze vijf bedrijven tezamen verwerken het grootste deel van het Nederlandse PE en PP.

\section{Huidige praktijk}

Slechts een klein deel van de geïnterviewde bedrijven gebruikt alleen gesorteerd huishoudelijk kunststofverpakkingsafval als grondstof. De meeste bedrijven gebruiken mengsels van bedrijfsmatig kunststofafval en huishoudelijk kunststofverpakkingsafval uit zowel bron en nascheiding als grondstof. De kwaliteit van de grondstoffen is een belangrijke zorg voor alle recyclingbedrijven.

Recyclingbedrijven hebben verschillende meningen over de onzuiverheden in de grondstof. Onzuiverheden die door meerdere bedrijven als uitdagend worden genoemd, zijn bijvoorbeeld top-seal folies voor schalen, lijmresten en siliconen rubber onderdelen. Daarnaast bevat gerecycled PP altijd $\mathrm{PE}$, wat zowel door sorteerfouten als verpakkingscomponenten veroorzaakt wordt; wanneer het aandeel PE meer dan $20 \%$ is, levert dit volgens de geïnterviewde bedrijven problemen op bij de verwerkbaarheid van rPP. In gerecycled PE zijn de meest uitdagende onzuiverheden bijvoorbeeld papier en hout, siliconen kitspuiten en een te groot aandeel PP (vanaf circa 15\%). 
De meeste recyclingbedrijven werken met een standaard mechanisch recycling proces, maar er zijn verschillende variaties. Het belangrijkste verschil in proces dat effect heeft op de kwaliteit van het eindproduct is flake-sortering.

De meeste bedrijven verhandelen compounds van kunststof recyclaat, sommige verhandelen granulaat van gerecycled kunststof, en andere bedrijven zelfs kunststof eindproducten gemaakt van recyclaat. Voor rPE zijn dit vooral extrusie producten zoals non-food flessen en emmers. Voor rPP zijn dit vooral spuitgiet producten zoals plantenpotten, vuilcontainers en tuinmeubelen. De ruime meerderheid van verkochte producten bestaat uit $100 \%$ recyclaat.

\section{Zakelijke uitdagingen}

Voor de meerderheid van de recyclingbedrijven is het een continue uitdaging om hun producten te verkopen. Belemmeringen waar ze tegenaan lopen zijn in het algemeen niet van technische aard, maar hebben te maken met: het vermijden van potentiële risico's (in inkoop specificaties), optische eigenschappen (kleur/glans), geur, wetgeving (bijvoorbeeld REACH) of andere algemene zakelijke problemen (bijvoorbeeld de relatief lage prijzen van nieuwe kunststoffen).

\section{Inzichten van het verpakkend bedrijfsleven}

Vijf vertegenwoordigers van het verpakkend bedrijfsleven zijn geïnterviewd; het was een heterogene groep, zowel in bedrijfsgrootte als soort bedrijf. De meeste bedrijven zijn al gebruikers van recyclaat, één bedrijf gaat binnenkort recyclaat gebruiken.

\section{Motivatie}

De belangrijkste motivatie van de producenten van consumentenartikelen om PE en PP recyclaat afkomstig van huishoudelijk kunststofverpakkingsafval te gaan gebruiken in hun verpakkingen is om de milieu impact van hun product-verpakkingscombinaties te verkleinen. Voor iedere productverpakkingscombinatie worden de verschillende mogelijkheden geëvalueerd op het gebied van technische haalbaarheid, kosten, verwachte milieu impact en marketing impact. Afhankelijk van het verpakkingsbeleid van het bedrijf wordt de meest geschikte optie geselecteerd.

\section{Belemmeringen}

De gebruikers ervaren meerdere belemmeringen wanneer ze rPE en rPP recyclaat willen gebruiken in hun verpakkingen. De meeste belemmeringen werden door meerdere bedrijven genoemd en zijn dus duidelijk gedeelde ervaringen. De recyclingindustrie is veel kleiner dan de virgin kunststof industrie en minder volwassen. Dit zorgt ervoor dat minder merken en soorten beschikbaar zijn en er is slechts een beperkt aantal grades van recyclaat beschikbaar t.o.v. virgin kunststof. Aangezien grote bedrijven typisch kilotonnen aan kunststof nodig hebben, zelfs voor hun kleinste producten, is hun uitdaging om deze verschillende, erg specifieke, kwaliteiten van gerecycled kunststof in voldoende grote hoeveelheden in te kopen.

In aanvulling hierop zijn er verschillende kwaliteitskwesties. Het belangrijkste probleem op het gebied van kwaliteit is voedselveiligheid; op dit moment zijn rPE en rPP niet beschikbaar voor voedsel toepassingen. Dit heeft ook secundaire effecten. Aangezien in veel verpakkingsmarkten, waaronder personal care, geen specifieke wetgeving van toepassing is, stellen sommige bedrijven als eis dat ook hiervoor food-grade materiaal wordt gebruikt. Een ander probleem is dat verschillende plastic converters verpakkingen voor zowel de food als non-food markten produceren. Aangezien ze moeten voldoen aan Hazard Analysis and Critical Control Point (HACCP) regels, is het vaak niet toegestaan om te werken met niet food-grade gerecycled kunststof. Naast voedselveiligheid zijn ook geur, kleur en kwaliteitsvariaties (slechts kleine afwijkingen zijn toegestaan) veel genoemde issues op het gebied van kwaliteit, waardoor het gebruik van gerecycled kunststof belemmerd wordt. Een andere uitdaging is dat PP en PE recyclaat zijn gemaakt van mengsels van verschillende grades, en onzuiverheden bevatten, die de verwerkbaarheid van de materialen kan beïnvloeden. 


\section{Analyse van de huidige kwaliteit van PP en PE recyclaat}

Zes recyclingbedrijven hebben samples van het door hen geproduceerde gewassen maalgoed en/of granulaat ter beschikking gesteld voor dit project.

\section{Gewassen maalgoed (snippers)}

De polymere zuiverheid van gewassen maalgoed is bepaald met een NIR-flakesorteer machine. Industrieel PP recyclaat gemaakt op basis van huishoudelijk kunststofverpakkingsafval bestaat vooral uit PP (92-94\%), een klein deel PE (3-4\%) en zeer kleine hoeveelheden (minder dan 1\%) andere onzuiverheden. Enkele van deze andere onzuiverheden zijn altijd aanwezig in zeer kleine hoeveelheden (PET, PS, PVC, Aluminium) en andere onzuiverheden zijn sporadisch aanwezig (PMMA, $\mathrm{PC}$, hout, papier, textiel).

Het industrieel beschikbare PE recyclaat gemaakt op basis van huishoudelijk kunststofverpakkingsafval bestaat uit 90-95\% PE, 2-7\% PP, 1-4\% zwart kunststof en verschillende onzuiverheden in zeer kleine hoeveelheden (minder dan 1\%). Dit ging voornamelijk over polymere onzuiverheden. PS was aanwezig in alle monsters in concentraties van $0.03-0.3 \%$. PET en PA waren in meer dan de helft van de monsters aanwezig in concentraties van respectievelijk $0.004-0.2 \%$ en $0.1-0.2 \%$.

De herkomst van onzuiverheden in de samples van PE en PP recyclaat is geanalyseerd met een al eerder gepubliceerd model. Het gaat hierbij om een materiaal-stroom analyse model van de Nederlandse recycling keten van huishoudelijk kunststofverpakkingsafval in 2014 en 2017 [Brouwer, et al. 2018, Brouwer, et al. 2019]. Het model laat zien dat in PE gewassen maalgoed circa $80 \%$ van de polymere onzuiverheden voortkomen uit de PE verpakkingen zelf, en dus is circa $20 \%$ het resultaat van andere, verkeerd gesorteerde producten. In het PP gewassen maalgoed is dit juist andersom: 15-20\% komt van de PP verpakkingen en $80-85 \%$ komt dus van sorteerfouten.

\section{Granulaat}

Het granulaat is geanalyseerd met verschillende analyse methoden:

- Polymeer vloei metingen: Melt Flow Index (MFI) en rotational rheometry (viscositeit).

- Chemische en thermische analyse: Differential Scanning Calorimetry (DSC) is gebruikt om de thermische eigenschappen van de verschillende monsters te bestuderen. Smelttemperaturen, kristalliniteit en zuiverheid van de monsters kan worden afgeleid uit deze metingen. Daarnaast is infrarood analyse (FTIR) gebruikt om de chemische samenstelling van de samples te bepalen en de aanwezigheid van onzuiverheden te onderzoeken. Voor een deel van de samples is ook Thermo Gravimetric Analysis (TGA) gedaan.

- $\quad$ Kleurmeting

De gemeten melt flow index voor de commerciële rPP en rPE producten bleek overeen te komen met de waarden in de bijbehorende datasheets. Er is veel variatie in MFI van de op de markt beschikbare rPP producten. De MFI waarden geven aan dat de rPP's geschikt zijn voor spuitgiet toepassingen en rPE's voor extrusie verwerking. Thermische analyse en infrarood spectroscopie bevestigen dat alle rPP samples $\mathrm{PE}$ als onzuiverheid bevatten en vice versa.

\section{Impact van onzuiverheden op PP en PE recyclaat}

Sample voorbereiding: van sorteerproduct tot gewassen maalgoed Om het effect van onzuiverheden in het PP en PE recyclaat te onderzoeken, is allereerst een monster gewassen maalgoed van beide materialen gemaakt met - op objectniveau - een hoge polymeerzuiverheid. Als start materiaal zijn gesorteerde PP en PE balen van een grote sorteerinstallatie in Nederland gebruikt. De samenstelling van het sorteerproduct dat als input van dit project is gebruikt, was vergelijkbaar met de gemiddelde samenstelling van Nederlandse sorteerproducten.

In het laboratorium zijn de materialen gesorteerd en alleen de fleslichamen van de flacons en de hoofdcomponenten van de andere vormvaste verpakkingen van het doelmateriaal werden geselecteerd. Om een hoge polymeerzuiverheid te bereiken, zijn alle andere materialen handmatig 
verwijderd: doppen en etiketten van niet-doelmaterialen, meerlaags verpakkingen, verpakkingen met veel productresten en verpakkingen met in-mould-labels.

De geselecteerde PP en PE objecten zijn (apart van elkaar) mechanisch gerecycled volgens een standaard recycling proces. Dit leverde gewassen maalgoed van beide materialen met een erg hoge zuiverheid op. De opbrengst van het mechanische recycling proces voor zowel PP als PE maalgoed was iets hoger dan die eerder werden gerapporteerd voor gesorteerd PP en PE. Dit wordt waarschijnlijk veroorzaakt door het feit dat de grondstoffen in dit onderzoek slechts 2 of 3 soorten doel verpakkingen bevatte en geen sorteerfouten. De op deze manier geproduceerde snippers hebben een polymere zuiverheid van meer dan $99.5 \%$, wat extreem hoog is in vergelijking met de industriële praktijk.

Als vervolgstap zijn verschillende bekende onzuiverheden toegevoegd aan de schone rPP en rPE snippers, om het effect van specifieke onzuiverheden te onderzoeken op de verwerkbaarheid en relevante materiaal eigenschappen. De samenstelling van de monsters en de keuze voor de onzuiverheden is gedaan op basis van de interviews en de analyse van het commercieel beschikbare materiaal, zodat realistische en relevante monsters zijn getest.

Figure S. 1 toont de beschrijving van de samples en analyses die voor rPP zijn uitgevoerd. Figure S. 2 laat dezelfde informatie voor rPE zien.

\begin{tabular}{|c|c|c|c|c|c|c|c|c|c|c|}
\hline Description & $\%$ & $\begin{array}{l}\text { MFI } \\
\text { (pellets) }\end{array}$ & $\begin{array}{l}\text { Spiral flow } \\
\text { (pellets) }\end{array}$ & $\begin{array}{l}\text { Charpy } \\
\text { Impact } \\
\text { (test } \\
\text { bars) } \\
\end{array}$ & $\begin{array}{l}\text { Density } \\
\text { (test } \\
\text { bars) }\end{array}$ & $\begin{array}{l}\text { Colour } \\
\text { (test } \\
\text { bars) }\end{array}$ & \begin{tabular}{|l} 
DSC \\
(pellets)
\end{tabular} & $\begin{array}{l}\text { DMTA } \\
\text { (test } \\
\text { bars) }\end{array}$ & \begin{tabular}{|l} 
FT-IR \\
(pellets)
\end{tabular} & $\begin{array}{l}\text { Viscosity } \\
\text { (compresse } \\
\text { d pellets) }\end{array}$ \\
\hline \multirow[t]{2}{*}{$\begin{array}{l}\text { Reference, } \\
100 \% \text { rPP }\end{array}$} & $0 \%$ & $V$ & $\checkmark$ & $\checkmark$ & $\checkmark$ & $\checkmark$ & $\checkmark$ & $\checkmark$ & $\checkmark$ & $\checkmark$ \\
\hline & $2 \%$ & $\checkmark$ & $\checkmark$ & $\checkmark$ & $\checkmark$ & $V$ & $\checkmark$ & $V$ & $\checkmark$ & $V$ \\
\hline \multirow[t]{2}{*}{ HDPE } & $5 \%$ & $\checkmark$ & $\checkmark$ & $\checkmark$ & $\checkmark$ & $\checkmark$ & $\checkmark$ & $\checkmark$ & $\checkmark$ & $\checkmark$ \\
\hline & $10 \%$ & $\checkmark$ & $V$ & $\checkmark$ & $\checkmark$ & $V$ & $\checkmark$ & $V$ & $\checkmark$ & $V$ \\
\hline LDPE & $2 \%$ & $\checkmark$ & $\checkmark$ & $\checkmark$ & $\checkmark$ & $\checkmark$ & $\checkmark$ & $V$ & $\checkmark$ & $\checkmark$ \\
\hline PET & $0.5 \%$ & $\checkmark$ & $\checkmark$ & $\checkmark$ & $\checkmark$ & $\checkmark$ & $\checkmark$ & $V$ & $\checkmark$ & $V$ \\
\hline PS & $0.5 \%$ & $\checkmark$ & $\checkmark$ & $\checkmark$ & $\checkmark$ & $V$ & $\checkmark$ & $\checkmark$ & $\checkmark$ & $\checkmark$ \\
\hline PVC & $0.5 \%$ & $\checkmark$ & $\checkmark$ & $\checkmark$ & $\checkmark$ & $\checkmark$ & $\checkmark$ & $\checkmark$ & $\checkmark$ & $\checkmark$ \\
\hline PP film & $3.5 \%$ & $\checkmark$ & $\checkmark$ & $\checkmark$ & $\checkmark$ & $\checkmark$ & $V$ & $\checkmark$ & $\checkmark$ & $V$ \\
\hline Aluminium & $0.5 \%$ & $\checkmark$ & $\checkmark$ & $V$ & $\checkmark$ & $\checkmark$ & $\checkmark$ & $\checkmark$ & $\checkmark$ & $\checkmark$ \\
\hline $\begin{array}{l}\text { In mould labels } \\
\text { (packages) }\end{array}$ & $50 \%$ & $\checkmark$ & $\checkmark$ & $\checkmark$ & $\checkmark$ & $V$ & $V$ & $\checkmark$ & $\checkmark$ & $\checkmark$ \\
\hline In mould labels & $5 \%$ & $\checkmark$ & $\checkmark$ & $\checkmark$ & $\checkmark$ & $\checkmark$ & $V$ & $V$ & $V$ & $V$ \\
\hline
\end{tabular}

Figuur S. $4 \quad$ rPP matrix die de monster variaties (rijen) weergeeft versus de analyse methoden (kolommen) die gebruikt zijn in dit project

\begin{tabular}{|c|c|c|c|c|c|c|c|c|c|c|}
\hline Description & $\%$ & $\begin{array}{l}\text { MFI } \\
\text { (pellets) }\end{array}$ & $\begin{array}{l}\text { Viscosity } \\
\text { (compress } \\
\text { ed } \\
\text { moulded } \\
\text { samples) }\end{array}$ & $\begin{array}{l}\text { Charpy } \\
\text { impact } \\
\text { (test } \\
\text { bars) }\end{array}$ & \begin{tabular}{|l|} 
Falling \\
dart \\
(extruded \\
sheet)
\end{tabular} & $\begin{array}{l}\text { Tensile } \\
\text { strength } \\
\text { (extruded } \\
\text { sheet) }\end{array}$ & $\begin{array}{l}\text { Density } \\
\text { (test } \\
\text { bars) }\end{array}$ & $\begin{array}{l}\text { Colour } \\
\text { (test } \\
\text { bars) }\end{array}$ & $\begin{array}{l}\text { DSC }+ \\
\text { crystallisa } \\
\text { tion } \\
\text { (pellets) }\end{array}$ & $\begin{array}{l}\text { FT-IR } \\
\text { (pellets) }\end{array}$ \\
\hline \multirow[t]{2}{*}{$\begin{array}{l}\text { Reference, } \\
100 \% \text { rPE }\end{array}$} & $0 \%$ & $V$ & $V$ & $V$ & $\checkmark$ & $\checkmark$ & $V$ & $\checkmark$ & $V$ & $V$ \\
\hline & $2 \%$ & $\checkmark$ & $\checkmark$ & $V$ & $V$ & $V$ & $V$ & $V$ & $V$ & $V$ \\
\hline \multirow[t]{2}{*}{ PP } & $5 \%$ & $V$ & $V$ & $V$ & $V$ & $V$ & $V$ & $V$ & $V$ & $\checkmark$ \\
\hline & $10 \%$ & $V$ & $V$ & $\checkmark$ & $V$ & $V$ & $\checkmark$ & $\checkmark$ & $V$ & $\checkmark$ \\
\hline \multirow{2}{*}{ LDPE } & $2 \%$ & $\checkmark$ & $\checkmark$ & $\checkmark$ & $V$ & $V$ & $V$ & $V$ & $V$ & $V$ \\
\hline & $5 \%$ & $V$ & $V$ & $V$ & $V$ & $V$ & $V$ & $V$ & $V$ & $V$ \\
\hline PET & $0.5 \%$ & $V$ & $V$ & $V$ & $V$ & $V$ & $V$ & $V$ & $V$ & $V$ \\
\hline PS & $0.5 \%$ & $V$ & $V$ & $V$ & $V$ & $V$ & $V$ & $V$ & $V$ & $V$ \\
\hline PVC & $0.5 \%$ & $V$ & $V$ & $V$ & $V$ & $V$ & $V$ & $V$ & $V$ & $V$ \\
\hline
\end{tabular}

Figuur S. 5 rPE matrix die de monster variaties (rijen) weergeeft versus de analyse methoden (kolommen) die gebruikt zijn in dit project 
Verwerking en analyse van rPP materiaal

Aangezien PP vooral wordt gebruikt voor spuitgiet toepassingen, is besloten om de analyse van de monsters toe te spitsen op eigenschappen die relevant zijn voor de verwerking en karakterisering van spuitgietproducten.

De rPP monsters zijn eerst gehomogeniseerd in een extruder, en vervolgens spuitgegoten tot teststaven. Beide verwerkingsstappen zijn goed gemonitord, om de invloed van verschillende onzuiverheden op het proces te onderzoeken. De monsters waaraan PET en gemetalliseerde folie zijn toegevoegd zijn relatief moeilijk te verwerken in een extruder met een filtratiesysteem, zoals in dit project gebruikt is. Kleine aluminium en siliconen deeltjes werden in alle filters teruggevonden, net als PET en nylon vezels, waarschijnlijk overblijfselen van verpakkingscomponenten. Alle bestudeerde materialen konden in relatief korte tijd worden spuitgegoten, net als de virgin referentie materialen.

Deze monsters zijn geanalyseerd met verschillende meetmethoden : polymeer vloei metingen, mechanische en fysische analyse, chemische en thermische analyse, zoals in Figure S. 1 staat. De MFI is een cruciale technische parameter in datasheets om de toepasbaarheid van een bepaald polymeer te beoordelen. MFI waarden van de diverse monsters worden gepresenteerd in Figure S. 3. Hier wordt duidelijk dat HDPE en LDPE de MFI van rPP materialen verminderen, zelfs al in hoeveelheden van $2 \%$. Dit is het geval voor de meeste andere toegevoegde onzuiverheden, maar het effect is kleiner. Monsters waar $50 \%$ van het materiaal is vervangen door schalen met in-mould labels laten juist een omgekeerd gedrag zien; MFI neemt toe ten opzichte van $100 \%$ rPP. Vergelijkbaar vloei gedrag is zichtbaar in de spiral flow meting.

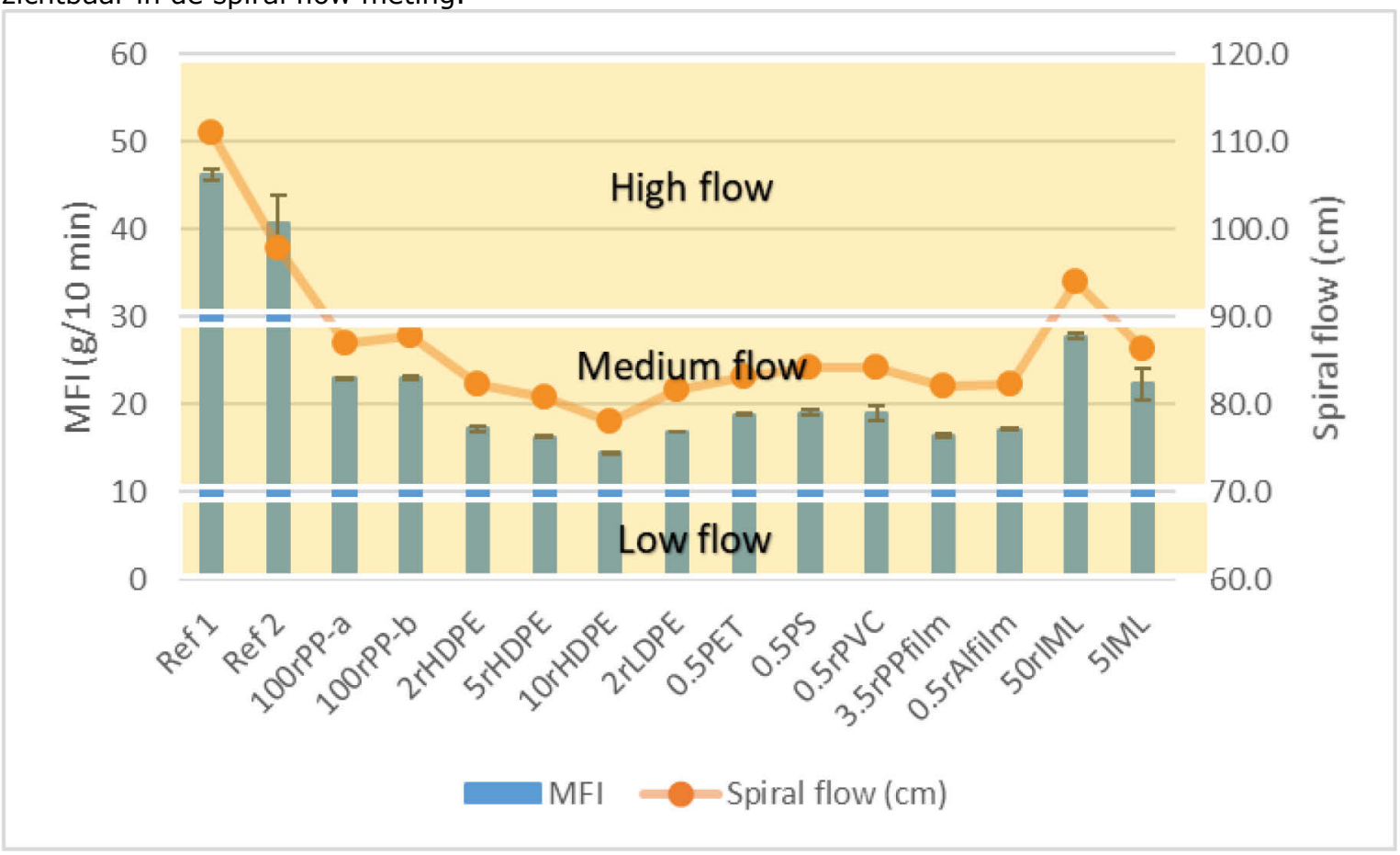

\section{Figuur S. 6 Vloei eigenschappen MFI en spiral flow bij $230^{\circ} \mathrm{C}$ van het bestudeerde rPP met verschillende onzuiverheden, vergeleken met twee high flow referentie materialen. Gebieden van hoge, medium en lage flow zijn gebaseerd op typische MFI waarden voor PP}

De slagsterkte van het $100 \%$ rPP monster (zonder toegevoegde onzuiverheden) is vergelijkbaar met één van de virgin referentie materialen. Toevoeging van verschillende percentages HDPE en LDPE laat de impact sterkte licht toenemen. Daarnaast blijkt uit de impact metingen dat verwerking op hogere temperaturen (sample 0.5PET-HT) de mechanische eigenschappen negatief beïnvloedt.

DMTA bevestigt wat met andere metingen ook werd gezien: de grootste verschillen worden waargenomen tussen de monsters van virgin materiaal en de samples van gerecycled PP. De rPP samples liggen allemaal dichtbij elkaar met weinig variatie, terwijl het relatieve verschil met virgin materialen groot is. 
Recyclaat heeft over het algemeen een donkerder kleur vergeleken met virgin materialen. Kleur wordt beïnvloed door de kleur/inkt van de ingezamelde verpakkingen, en daarom is het donkerder en kent meer kleurtonen dan de virgin materialen die wit of transparant zijn. Het toevoegen van onzuiverheden levert aanzienlijke kleur verschillen t.o.v. de referentie $100 \%$ rPP. Deze verschillen kunnen niet direct worden toegeschreven aan de kleur van de toegevoegde onzuiverheden, behalve in het geval van de in-mould labels. Polymeren zoals PET zijn slecht mengbaar met PP, en daarom kan zelfs een kleine hoeveelheid de kleur al flink veranderen. Ook de verwerkingstemperatuur kan invloed hebben op de kleur, dit is zichtbaar in het 0.5PET-HT monster.

\section{Analyse van het rPE materiaal}

PE wordt vooral gebruikt in extrusie toepassingen, en daarom ligt de nadruk bij de analyse op eigenschappen die relevant zijn voor geëxtrudeerde producten. Na extrusie, zijn sheets gemaakt en ook teststaafjes spuitgegoten.

De meeste deeltjes die na extrusie van rPE op de filters werden gevonden, zijn anders dan de deeltjes die na extrusie van rPP werden gevonden. De enige uitzondering is aluminium, dat op beide sets smeltfilters werd teruggevonden. Witte siliconen rubber deeltjes zijn waarschijnlijk afkomstig van productrest van kitkokers of verpakkingscomponenten zoals anti-lek ventielen. . Ondanks de aanwezigheid van onzuiverheden in het $100 \%$ rPE materiaal en de toegevoegde onzuiverheden, konden alle geproduceerde rPE samples geëxtrudeerd worden tot sheets en ook spuitgegoten. Spuitgiet tijden waren echter extreem lang voor de samples die LDPE en PET bevatten.

De vloei van PE werd alleen beïnvloed door de toevoeging van grote hoeveelheden PP (meer dan $5 \%$ ). De andere toegevoegde onzuiverheden hadden geen significante invloed op de MFI van rPE. Dit komt overeen met de viscositeitscurves.

PE soorten op de markt zijn over het algemeen ontworpen om bepaalde impact sterkte eigenschappen te behalen, zodat ze geschikt zijn voor specifieke toepassingen zoals flesblazen. Flesblaas toepassingen vereisen lage MFI waarden en erg hoge slagsterktes. De slagsterkte van alle rPE monsters was lager dan de virgin referentie, maar er zijn toepassingen in de markt waar deze waarden voldoende zou zijn. De graad van kristalliniteit die bereikt kan worden met alle rPE samples is lager dan wat bereikt kan worden met de virgin referentie. Dit zou de uiteindelijke toepassing van de verpakking kunnen beïnvloeden.

Monsters van rPE zijn niet wit, omdat ze niet op kleur gesorteerd zijn. Wanneer de samples met onzuiverheden vergeleken worden met het 100\% rPE sample, blijkt dat de grootste kleurverschillen worden waargenomen voor de kleinste hoeveelheden van toegevoegde onzuiverheden: $0.5 \%$ PET, PS en PVC.

\section{Discussie}

Er is niet heel veel wetenschappelijke literatuur beschikbaar over de aard en eigenschappen van gerecyclede kunststoffen. De meest relevante technische inzichten zijn kort geïntroduceerd en vergeleken met de resultaten van dit project. Bovenop de huidige kennis vanuit de literatuur, heeft deze studie nieuw inzicht gegeven in de eigenschappen van gerecyclede kunststoffen. Deze studie laat zien dat de verwerkbaarheid en eigenschappen van PP en PE recyclaat worden beïnvloed door drie factoren:

1) Polymere zuiverheid: blends van verschillende grades van polymeren of hetzelfde type polymeer.

2) Aanwezigheid van onzuiverheden: gaat zowel over de aanwezigheid van polymere onzuiverheden als over andere materialen (papier, textiel, etc.). Aanwezigheid van additieven.

Dit verklaart dat PP en PE recyclaat - zelfs met een zeer hoge polymere zuiverheid - altijd andere eigenschappen dan virgin materiaal zal hebben. Recyclaat op basis van huishoudelijk kunststofverpakkingsafval is van nature een mengsel van verschillende specifieke grades met als resultaat gemiddelde eigenschappen. Deze situatie is - los van juridische en zakelijke uitdagingen een belangrijke reden voor de huidige mismatch en vraag en aanbod van recyclaat. Om deze uitdagende situatie te doorbreken en een hoger niveau van circulariteit te bereiken voor PP en PE, zijn meerdere routes mogelijk. 


\section{Conclusie en aanbevelingen}

Allereerst zal design-for-recycling van verpakkingen in combinatie met een betere naleving van bestaande specificaties voor de sorteerproducten de hoeveelheid onzuiverheden in het gewassen maalgoed reduceren, en daarmee ook in het granulaat. Bovendien kan de introductie van kwaliteitsspecificaties op tussenproducten zoals gewassen maalgoed de kwaliteit van de geproduceerde granulaat verbeteren. Dit onderzoek kan gebruikt worden als een eerste verkenning. Echter, om specificaties op te stellen, is meer diepgaand onderzoek nodig.

Een tweede route is de toepasbaarheid van bestaande gerecyclede kunststoffen te verbeteren door verwerkbaarheid te verbeteren en nieuwe toepassingsgebieden te introduceren. In een vervolgproject zouden extra meetmethoden moeten worden toegevoegd om de scope van toepasbaarheid te vergroten. Als alternatief, kan het recyclaat meer geschikt worden gemaakt voor een specifieke toepassing door het gebruik van additieven, aanpassing van de verwerkingsparameters en/of herontwerp van het eindproduct. Dit wordt design-from-recycling genoemd en hierbij moeten alle partners in de keten betrokken worden.

De meest uitgebreide route zou een nieuw systeem zijn, gebaseerd op geavanceerde sorteer technieken. Ideeën zijn bijvoorbeeld om op verschillende grades te gaan sorteren of om markeertechnologie te gebruiken om food-safe toepassingen voor rPP en rPE mogelijk te maken.

Samengevat zijn er meerdere routes mogelijk om de circulariteit van PE en PP te verhogen. Ongeacht welke route(s) gevolgd wordt/worden, is actieve deelname van alle stakeholders noodzakelijk, inclusief de EU en nationale overheden om beleid op te zetten in een of meer van deze richtingen. 


\section{Introduction}

Recycling of post-consumer plastic packaging waste is a crucial part of the circular economy European countries strive for. Currently there is a gap between the quality of the recycled plastics that is available on the market on one hand and the demands from potential users on the other hand. One of the aims of this project is to further understand the reasons for this mismatch between supply and demand. The barriers that both industries experience in attempting to close this gap are analysed. Furthermore a first assessment is performed on the impact of impurities on processing and application of recycled PE (polyethylene) and PP (polypropylene). This is valuable input in discussions on the future of recycling systems for post-consumer plastics. For example, this knowledge could be used as a base for new, future quality standards and specifications.

\section{Background}

The recycling of post-consumer plastic packaging waste has evolved rapidly over the last decade. Roughly 103 kton of washed milled goods (the output product of mechanical recycling) were produced from the post-consumer plastic packaging waste that was either separately collected or mechanically recovered from mixed municipal solid waste (MSW) in the Netherlands in 2017 [Brouwer et al. 2019]. Five types of recycled plastics were produced, from the sorted products PET (Polyethylene terephthalate) bottles, PE, PP, Film and Mixed plastics. Four of these five recycling products are intrinsically suited for 'circular applications', implying that the recycled products can be used to produce either new packages or similarly demanding applications (consumer articles, crates, boxes, casings, automotive parts, etc.).

From these four, the recycling product made from PET bottles has been studied the most. The technologies to produce food-grade recycled PET from collected PET bottles have been developed [Welle, 2011] and multiple studies have been conducted on the properties that make recycled PET suitable for application in bottles and trays [Masmoudi et al. 2018, Welle 2011]. Additionally the relation between the presence of impurities and the properties of recycled PET have been studied [Alsewailem et al. 2018, Snell et al. 2017, Thoden van Velzen et al. 2016 B], leading to the definition of concentration threshold values for impurities at which the application in PET bottles becomes undesired [Brouwer et al. submitted].

For two other rigid recycled plastics ( $r P E$ made from sorted product DKR ${ }^{1} 329$ and rPP made from sorted product DKR 324) substantial improvements have been witnessed over the past years in its use. More and more of these recycled plastics are used in circular applications such a non-beverage bottles, crates, paint pots, etc. However, the required properties of these recycled plastics to enable these circular applications have not been thoroughly described, nor has the influence of impurities on the properties systematically been studied, yet. Filling this knowledge gap would facilitate circular applications and make a meaningful contribution in our shared ambition to achieve a more circular economy for plastic packages. Therefore this project focuses on rPP and rPE.

The fourth recycling product with circularity potential is sorted product Film (DKR 310). Similar as with rPE and rPP an increasing number of flexible products are currently being made from recycled product Film. Therefore there is a need for more research into the requirements to recycle this material into flexible film products. However, due to financial constraints, it was chosen to focus this project on recycled PE and recycled PP.

\footnotetext{
${ }^{1}$ DKR specifications are standards for quality and purity of sorting products, as established by DKR. https://www.gruenerpunkt.de/de/downloads.html
} 
Objectives

The research described in this report had multiple objectives:

- $\quad$ Provide a better understanding of the impurities that occur regularly in recycled PE and recycled $\mathrm{PP}$, both with regard to different materials and polymers.

- $\quad$ Reach a better understanding of the critical properties of recycled PE and PP to enable circular applications.

- Improve the understanding of how impurities affect the applicability of the recycled plastics, by systematically studying the impact of impurities on the properties of recycled plastics.

- Understand the opinions of two sets of stakeholders in relation to the quality of recycled plastics and their potential use in packages; the recycling industry as producer and the fast moving consumer goods industry as customer for the recycled PE and PP.

This research effort should result in a better scientific understanding of the impurities that occur in rPE and rPP and how their presence affects the applicability of these recycled plastics. This is valuable information in discussions on the future of recycling systems for post-consumer plastics. For example, this knowledge could be used as a base for new, future quality standards and specifications.

The project has been divided in the following main tasks/topics, which will be described in detail in this report.

Task 1: Perceptions of the plastic recycling industry: in chapter 3 the results of interviews with plastic recycling industry are presented. Besides current practices, business barriers are listed

Task 2: Perceptions of the packaging industry : chapter 4 describes the outcome of interviews with some packaging companies (potential users of recycled material). After a description of the motivation, some barriers in the use of recycled PP and PE are mentioned

Task 3: Analysis of current quality of recycled PP and PE : see chapter 5 for the results

Task 4: Impact of impurities in PP and PE recycled plastics : see chapter 6 for the results

All methods are described in chapter 2. The report ends with a discussion, conclusion and recommendations.

\section{Scope}

This research is limited to recycled PE made from DKR 329 and recycled PP made from DKR 324. These sorted products originate from Dutch post-consumer plastic packaging waste. The research is limited to those impurities that regularly occur in recycled PE and PP or are likely to occur regularly in recycled PE and PP. The studied properties of the recycled plastics are limited to those that are relevant for the polymers and their applications.

\section{Project}

The research was conducted by researchers of Wageningen Food \& Biobased Research in 2019. The client of this project was Nedvang and it has been financed by Stichting Afvalfonds. The research was conducted independently. The intended result of this project is an English language report, which was written by a group of scientists and reviewed internally.

This report is publicly available after approval by Nedvang. 


\section{Methods}

\subsection{Task 1: Perceptions of the plastic recycling industry}

Interviews were held with four Dutch and one German recycling industries to probe their interest in new quality standards for recycled plastics. The five recycling industries were selected based on their relative importance in processing Dutch sorted PE and PP products (DKR 329 and 324, respectively). With these five companies the main volume of Dutch sorted PE and PP products is covered. Meetings were scheduled with representatives of the recycling industries. Prior to the meeting the goal of the meeting and information about the research project was shared with the representatives. The interviews were held organically, and during the interviews a checklist of questions (see Appendix F) was used to make sure all interviews at least addressed the same topics. Relevant comments that were outside the scope of the checklist were also recorded. The results were analysed and the most common answers and some important anecdotes were reported.

\subsection{Task 2: Perceptions of the packaging industry}

Interviews were conducted with five representatives of companies that use recycled PE and/or PP in their packages. Most of them are current users and one of them is a near-future user. It was a heterogenous group in size (two large enterprises and three small enterprises) and type (e.g. Fast moving consumer good (FMCG) producers, packaging producers, retailers). The approach to the interviews and reporting method were the same as described above (see section 2.1 and Appendix $F$ for checklist of questions).

\subsection{Task 3: Analysis of current quality of recycled PP and PE}

In order to get a reliable indication of the current quality of commercially available recycled PP and PE, samples of flakes and pellets were requested and obtained from several relevant recycling companies. In Table 2.1 and Table 2.2 the received samples are listed. In total 6 different companies sent samples (B1 - B6), some companies sent only flakes (indicated with an M) or only pellets (indicated with a G) and some of them sent us multiple samples of different products or of the same product from different production dates. Flakes are usually only an intermediate product and not directly sold but processed within the same company to pellets, compounds or products. Therefore, most companies do not have datasheet on flakes available. On the other hand, pellets are usually supplied with a corresponding technical data sheet, some of the data made available by the suppliers is listed in Table 2.3. Flakes were analysed on composition. Pellets were analysed on rheological properties (in this report called polymer melt flow properties), chemical and thermal properties, and pellet colour.

Table 2.1 Received samples of PP flakes and pellets.

\begin{tabular}{llll} 
Sample & Company & Type & Colour \\
B1-PP-1M & Company 1 & Washed milled goods & Mixed flakes \\
\hline B1-PP-2M & Company 1 & Washed milled goods & Mixed flakes \\
\hline B3-PP-3M & Company 3 & Washed milled goods & Mixed flakes \\
\hline B1-PP-1G & Company 1 & Pellets & Terracotta \\
\hline B1-PP-2G & Company 1 & Pellets & Black \\
\hline B1-PP-3G & Company 1 & Pellets & Grey \\
\hline B2-PP-4G & Company 2 & Pellets & Natural \\
\hline B2-PP-5G & Company 2 & Pellets & White \\
\hline B3-PP-6G & Company 3 & Pellets & Black \\
\hline
\end{tabular}


Table 2.2 Received samples of PE flakes and pellets.

\begin{tabular}{llll} 
Sample & Company & Type & Colour \\
B4-PE-1M & Company 4 & Washed milled goods & Mixed flakes: source of grey pellets \\
\hline B4-PE-2M & Company 4 & Washed milled goods & White/ivory flakes: source of ivory pellets \\
\hline B5-PE-3M & Company 5 & Washed milled goods & Mixed flakes \\
\hline B5-PE-4M & Company 5 & Washed milled goods & Mixed flakes \\
\hline B5-PE-5M & Company 5 & Washed milled goods & Mixed flakes \\
\hline B6-PE-6M & Company 6 & Washed milled goods & Mixed flakes \\
\hline B6-PE-7M & Company 6 & Washed milled goods & Mixed flakes \\
\hline B4-PE-1G & Company 4 & Pellets & Grey \\
\hline B4-PE-2G & Company 4 & Pellets & Ivory
\end{tabular}

Table 2.3 Technical data of PP and PE pellets supplied in the corresponding data sheets.

\begin{tabular}{|c|c|c|c|c|c|}
\hline Sample & Material & Origin & Application & Density $\left(\mathrm{g} / \mathrm{cm}^{3}\right)$ & MFI (g/10 min) \\
\hline B1-PP-1G & PP & $\begin{array}{l}\text { washed post } \\
\text { consumer regrind }\end{array}$ & $\begin{array}{l}\text { Injection } \\
\text { moulding }\end{array}$ & $0.92-0.97$ & $\begin{array}{l}50 \\
@ 230 \mathrm{C} / 2.16 \mathrm{~kg}\end{array}$ \\
\hline B1-PP-2G & PP & $\begin{array}{l}\text { washed post } \\
\text { consumer regrind }\end{array}$ & $\begin{array}{l}\text { Injection } \\
\text { moulding }\end{array}$ & $0.91-0.95$ & $\begin{array}{l}40 \\
\text { @ } 230 \mathrm{C} / 2.16 \mathrm{~kg}\end{array}$ \\
\hline B1-PP-3G & $\mathrm{PP}$ & $\begin{array}{l}\text { washed post } \\
\text { consumer regrind }\end{array}$ & $\begin{array}{l}\text { Injection } \\
\text { moulding }\end{array}$ & $0.90-0.95$ & $\begin{array}{l}45 \\
@ 230 \mathrm{C} / 2.16 \mathrm{~kg}\end{array}$ \\
\hline B2-PP-4G & PP & $\begin{array}{l}\text { post-consumer } \\
\text { scraps }\end{array}$ & $\begin{array}{l}\text { Injection } \\
\text { moulding }\end{array}$ & 0.913 & $\begin{array}{l}17 \\
@ 230 \mathrm{C} / 2.16 \mathrm{~kg}\end{array}$ \\
\hline B2-PP-5G & PP & $\begin{array}{l}\text { post-consumer } \\
\text { scraps }\end{array}$ & $\begin{array}{l}\text { Injection } \\
\text { moulding }\end{array}$ & 0.94 & $\begin{array}{l}21 \\
@ 230 \mathrm{C} / 2.16 \mathrm{~kg}\end{array}$ \\
\hline B3-PP-6G & PP & PCW packaging & $\begin{array}{l}\text { Manufacturing of } \\
\text { plastics products }\end{array}$ & $0.90-0.95$ & Not available \\
\hline B4-PE-1G & $\mathrm{PE}$ & $\begin{array}{l}\text { At least } 95 \% \text { PC } \\
\text { from pre-sorted } \\
\text { plastic packaging } \\
\text { waste }\end{array}$ & $\begin{array}{l}\text { Blow moulding \& } \\
\text { extrusion } \\
\text { application }\end{array}$ & 0.956 & $\begin{array}{l}0.4 \text { @ } 190 \mathrm{C}, 2.16 \mathrm{~kg} \\
1.8 @ 190 \mathrm{C}, 5 \mathrm{~kg}\end{array}$ \\
\hline B4-PE-2G & $\mathrm{PE}$ & $\begin{array}{l}\text { At least } 95 \% \text { PC } \\
\text { from pre-sorted } \\
\text { plastic packaging } \\
\text { waste }\end{array}$ & $\begin{array}{l}\text { Blow moulding \& } \\
\text { extrusion } \\
\text { application }\end{array}$ & 0.956 & $\begin{array}{l}0.3 @ 190 \mathrm{C}, 2.16 \mathrm{~kg} \\
1.5 @ 190 \mathrm{C}, 5 \mathrm{~kg}\end{array}$ \\
\hline
\end{tabular}

\subsubsection{Analysis of the polymeric composition of flakes}

In order to analyse the purity of a flake sample in terms of polymeric composition, the flakes were analysed with the SIROPAD, see Figure 2.1 and Figure 2.2. All flakes had sub-centimetre sizes, most were in 3-7 $\mathrm{mm}$ size range. Samples of about 10 grams were weighted and spread evenly over the measurement surface of the device, assuring that all flakes are lying free on the surface without overlap. The scanner is set in the "All" measuring mode. First the flakes are scanned roughly with a line step of $6 \mathrm{~mm}$, all other settings were kept in "default-mode". After this rough first scan is completed, all flakes from a different polymer type are pin-pointed, removed manually and laid on the measuring surface near the side border. Subsequently two more scans are made in the "default, all" mode (line-step of $3 \mathrm{~mm}$ ), which is slower and more accurate. Again particles from different polymers are laid aside, and simultaneously the polymer particles that had been set aside are checked. At the end, the separated flakes of a specific polymer are weighted on the analytical balance. These weights are used to calculate the mass based polymeric compositions.

In case other materials like metals, glass or wood are found, these are laid aside and also weighted separately. 

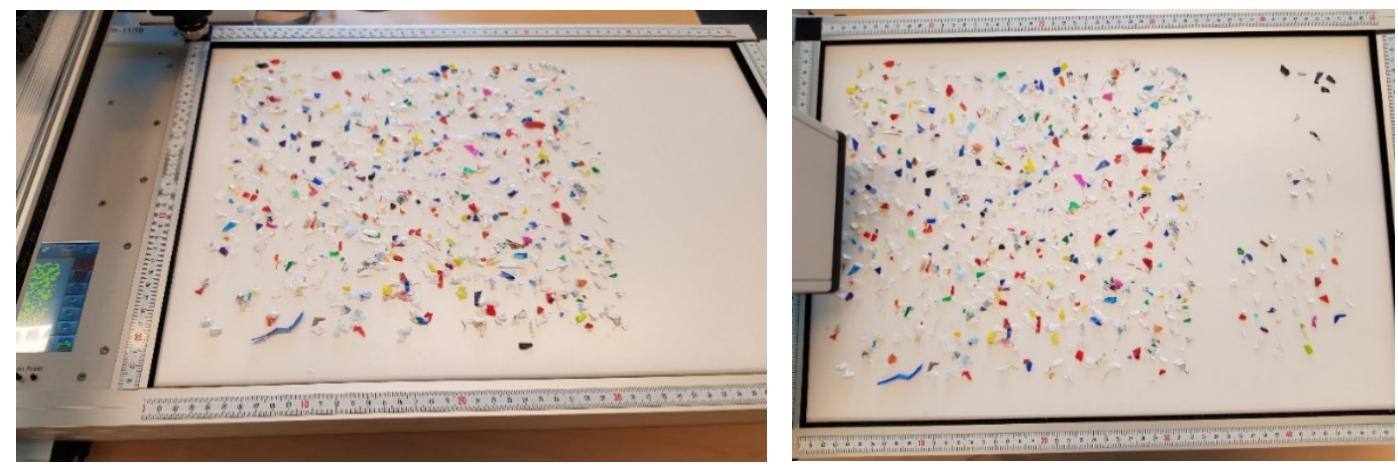

Figure 2.1 The SIROPAD flake analyser in different stages of the analyses. Left during a first, exploratory scan and right during a more precise later scan

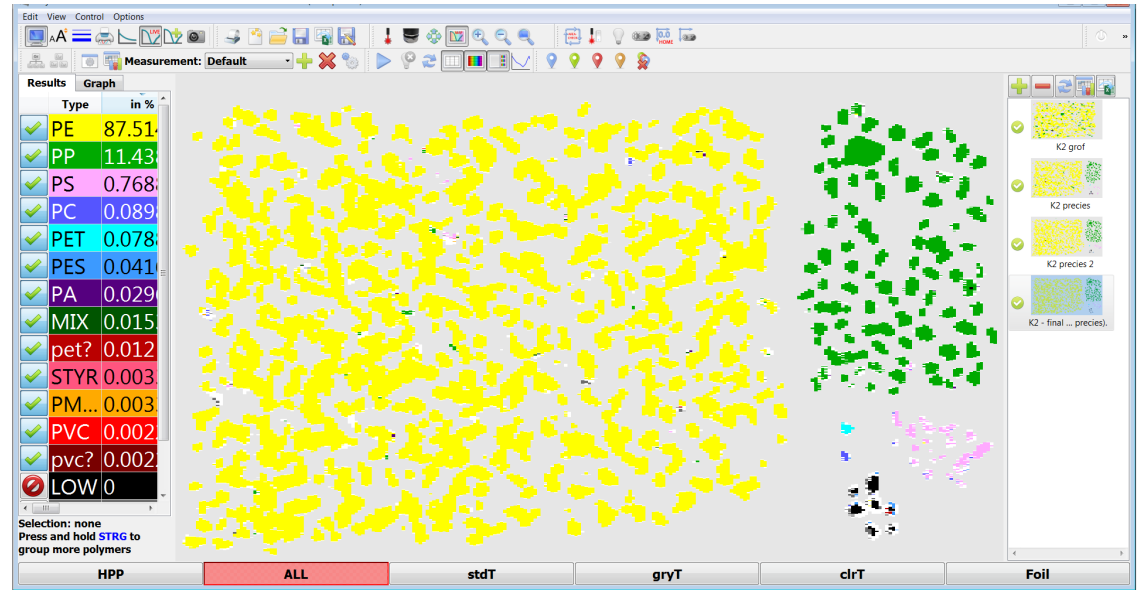

Figure 2.2 A screen shot of a random sIRoPAD flake analysis. Colours show different polymer types

\subsubsection{Pellets characterisation}

\subsubsection{Polymer melt flow measurements}

The flow properties of the received recycled plastic pellets were analysed with two kinds of measurements, melt flow index (MFI) and rotational rheometry (viscosity). Since the received PP and PE are expected to have different melt flow properties, different settings were used.

MFI was measured using a Zwick Roell Mflow MFI tester. Tests were done according to ISO 1133 . For rPP samples, tests were done at $230^{\circ} \mathrm{C}, 2.16 \mathrm{~kg}$ and for rPE samples, tests were done at $190^{\circ} \mathrm{C}, 5 \mathrm{~kg}$. The average of three measurements and its corresponding standard deviation are reported. These measurements were performed in the pellets as such.

Viscosity curves were measured in the ARES-rotational rheometer from TA Instruments using a parallel plate geometry with $25 \mathrm{~mm}$ diameter stainless steel plates. In order to determine the linear viscoelastic region (LVR), strain sweep scans were done at $190^{\circ} \mathrm{C}$ for PP and at $180^{\circ} \mathrm{C}$ for PE in the range $0.01 \%-50 \%$ oscillation strain. From these scans, a strain of $1 \%$ was chosen to execute the frequency sweeps. Frequency sweeps were done at 3 different temperatures, $200^{\circ} \mathrm{C}, 180^{\circ} \mathrm{C}$ and $160^{\circ} \mathrm{C}$ for PP and $180^{\circ} \mathrm{C}, 160^{\circ} \mathrm{C}$ and $140^{\circ} \mathrm{C}$ for $\mathrm{PE}$ in the region 0.01 to $100 \mathrm{~Hz}$. Since the measurements at different temperatures are performed within the LVR, they can be combined to obtain a so called master curve at the maximum temperature. This master curve shows the viscosity of the polymer at varying shear rates. The shear rate range is widened by joining the different curves into a master curve. These rheometry measurements were performed in compressed moulded $2 \mathrm{~mm}$ thick cylindric samples. Compression moulding was done at $230^{\circ} \mathrm{C}$ for both rPP and rPE samples. The viscosity data at $200^{\circ} \mathrm{C}$ for PP and at $180^{\circ} \mathrm{C}$ for PE are reported. 


\subsubsection{Chemical and thermal analysis}

Differential Scanning Calorimetry (DSC) was used to study the thermal properties of the received samples. Melting temperatures, degree of crystallinity and purity of the samples can be derived from these measurements. Furthermore, Infrared analysis (FTIR) was used to study chemical composition of the samples and to verify the presence of impurities.

DSC was performed using a Perkin Elmer DSC 8000 series. Samples were held for 2 minutes at $0^{\circ} \mathrm{C}$ and then heated from $0^{\circ} \mathrm{C}$ to $260^{\circ} \mathrm{C}$ at a speed of $10^{\circ} \mathrm{C} / \mathrm{min}$. Large volume stainless steel cups were used. For all samples, several peaks were found. For each peak the following parameters are reported: The temperature of the peak maximum and the area below the peak indicated as the difference in enthalpy $(\Delta \mathrm{H})$. In order to calculate the degree of crystallinity of a PP sample $(X \%)$ a value of $\Delta \mathrm{H}_{\mathrm{m}}{ }^{0}=207 \mathrm{~J} / \mathrm{g}$ for $100 \%$ crystalline PP was used. In the case of PE samples, $100 \%$ crystallinity implies a $\Delta \mathrm{H}_{\mathrm{m}}{ }^{0}=293 \mathrm{~J} / \mathrm{g}$. In previous studies done at WFBR with recycled $\mathrm{PE}$, a value of $186 \mathrm{~J} / \mathrm{g}$ has been found for a sample made of $100 \%$ rPE from one type of packaging, therefore this value was used here to estimate the amount of PE present in the received rPP and rPE samples.

Fourier transform infrared (FT-IR) spectra was performed on the received pellets with a Varian Scimitar 1000 FT-IR spectrometer equipped with a DTSG-detector in the attenuated total reflectance (ATR) mode. The measurement resolution was set at $4 \mathrm{~cm}^{-1}$, and the spectra were collected in the range $4000-650 \mathrm{~cm}^{-1}$ with 50 co-added scans. The sample chamber was purged by $\mathrm{N}_{2}$ gas for 10 minutes before scanning was started.

Since an unexpected exothermic peak was found in all rPP pellet samples received, one sample per company was selected for thermo gravimetric analysis (TGA) in order to gather more information to understand the nature of this unexpected peak. Tests were performed using a Perkin Elmer STA 600 Thermo Gravimetric Analyser. The temperature range was $30-900^{\circ} \mathrm{C}$ and the heating rate $10^{\circ} \mathrm{C} / \mathrm{min}$ under an air atmosphere.

\subsubsection{Colour characterization}

Colour of the received pellets was measured using Konica Minolta Chroma meter CR-400 according to the CIELAB method. Granulate was spread on a petri dish and 5 measurements per sample were done. As background reference a white tile was used. This yielded three colour parameters: $L^{*}\left(100=\right.$ white; $0=$ black), $a^{*}$ (positive=red; negative=green; $0=$ grey) and $b^{*}$ (positive=yellow; negative=blue; $0=$ grey).

\subsubsection{Model analysis on origin of impurities}

The origin of impurities in recycled PE and PP samples was tracked using an already published material-flow analysis model of the Dutch recycling chain of post-consumer plastic packaging waste in 2014 and 2017 [Brouwer, et al. 2018, Brouwer, et al. 2019]. This material-flow analysis (MFA) describes the collection, sorting and mechanical recycling of household plastic packaging waste. The system boundaries of this model are: the design and types of packages at households in terms of material composition and the amount of produced washed milled goods. In this model a detailed description of the composition of the recycling products is calculated. This provides the opportunity to check the origin of impurities in the washed milled goods, which could be either parts of the targeted packages (as packaging components) or faulty sorted objects of a different polymer type. This origin of impurities was available for 2014 and for 2017, as well as for washed milled goods from separate collection and mechanical recovery from MSW. The results for these four sub-models were combined to ranges of origins of impurities. Small changes in compositions of the sorted products between 2014 and 2017 already had a great impact on the origin of the impurities. Also, the composition of sorted products differ between separate collection and mechanical recovery. Hence, the origin of the impurities is only an estimation. 
Other impurities, besides the polymeric impurities, could be found in the PE and PP washed milled goods as well. However, in the model paper, sand, metals, glass, etc. are all completely separated from the floating fraction, which is the main product for PE and PP washed milled goods. Therefore for the estimation of the origin of these impurities the composition of the sorted products was used.

\subsection{Task 4: Impact of impurities in PP and PE recycled plastics}

In task 4, the impact of impurities in PP and PE recycled plastics on their properties was studied. This section explains how the samples were prepared for testing and how the tests were performed. As it is shown in Figure 2.3 and Figure 2.4 the initial steps of sample preparation were identical for both rPP and rPE material: sorting and mechanical recycling up to washed milled goods. The sorting process is described in 2.4.1.1 and the mechanical recycling method in 2.4.1.2. Furthermore, the type and amount of impurities added are described in 2.4.2. As a next step the washed milled goods of both PP and PE were extruded to pellets. For rPP the extrusion process is described in 2.4.3.1 and for rPE in section 2.4.4.1. The final step for sample preparation was different for both materials, because of their different application in industry. PP recycled material is mainly used for injection moulding applications, therefore test bars were manufactured by injection moulding (see 2.4.3.2). For PE recycled material the focus in industry is mainly on extrusion blowing applications, therefore it was chosen to produce extruded sheets to get an indication of the behaviour of the materials in more general extrusion applications (see 2.4.4.3).

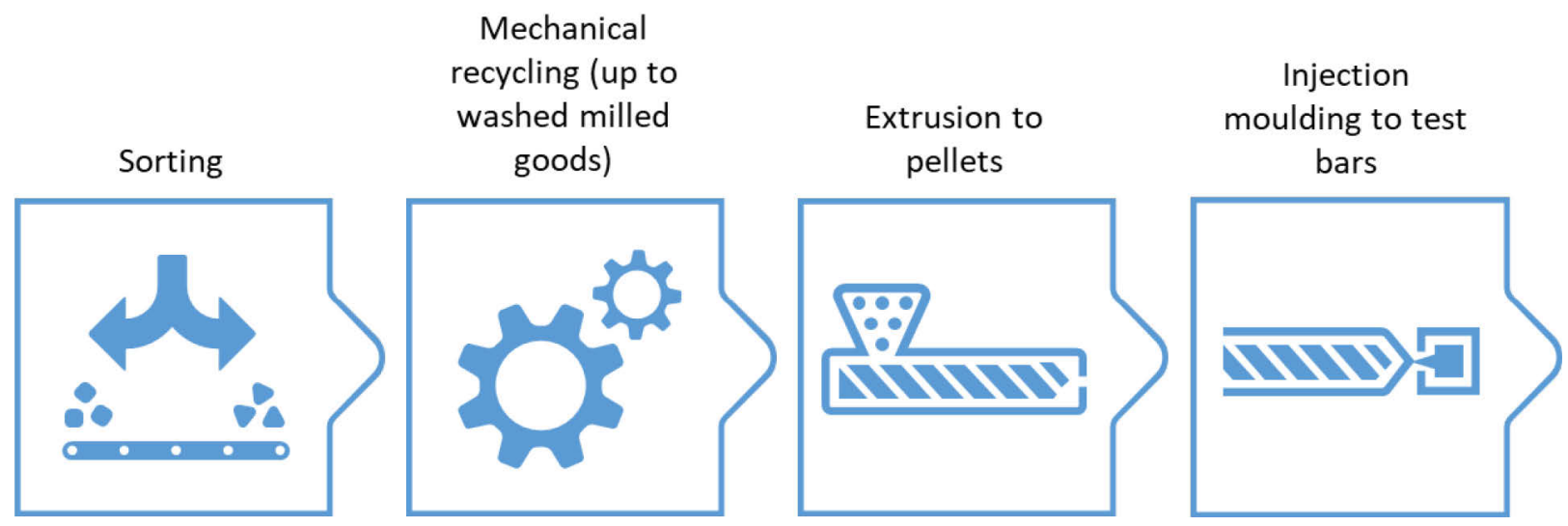

Figure 2.3 Recycled PP sample preparation

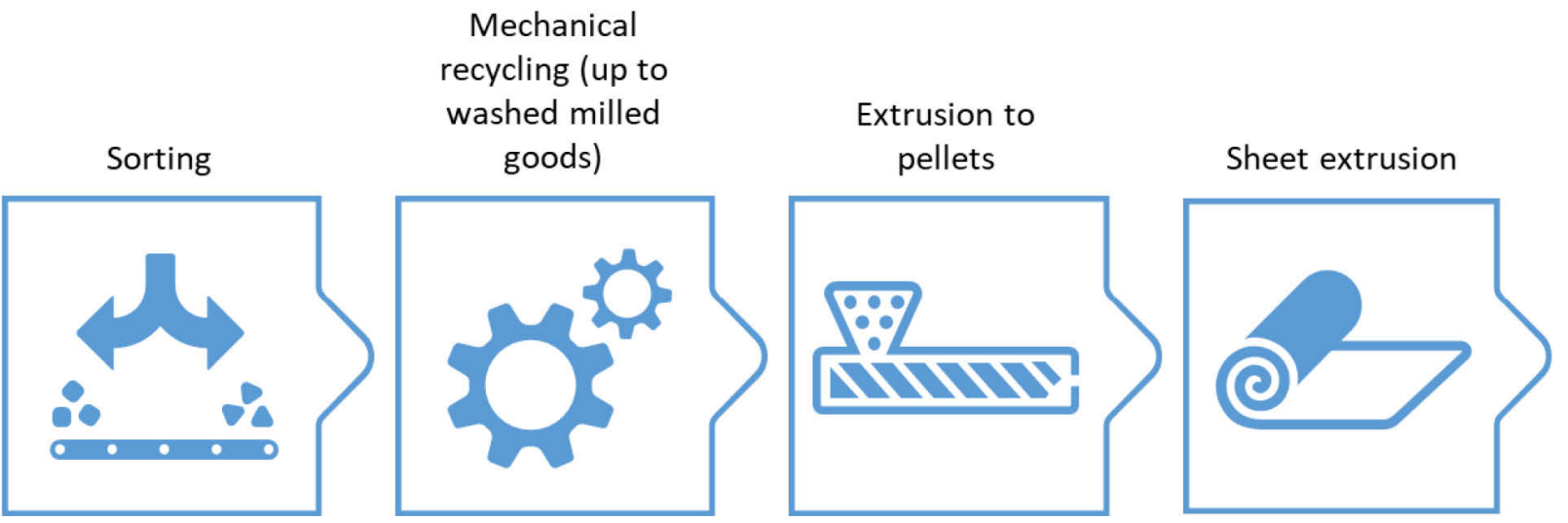

Figure 2.4 Recycled PE sample preparation 


\subsubsection{From sorted product to washed milled goods}

In order to analyse the impact of impurities in the recycled PP and PE material, a base sample of washed milled goods of both materials was prepared as a starting point. Known quantities of various other materials can then be added to these reference samples, simulating the different potential impurities which might occur in reality. This section describes how the base samples were prepared.

\subsubsection{Sorting received sorted products and separating PP and PE rigid objects}

For this trial, the starting materials were the regular sorted products supplied by a large sorting facility in the Netherlands. For rigid PE the DKR-329 product was used and for rigid PP the DKR-324 product. See Figure 2.5 for a picture of the sorted bales.
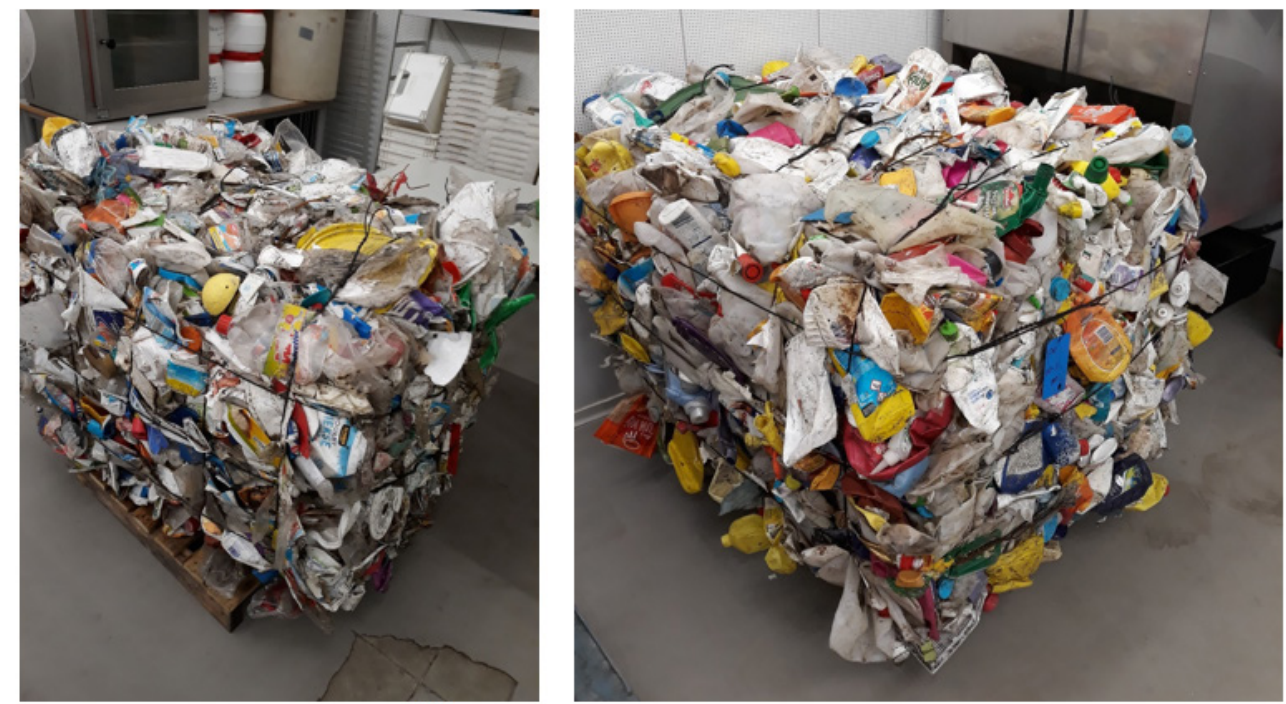

\section{Figure 2.5 The regular sorted bales for PP (left, DKR 324) and PE (right, DKR 329) as received from a sorting facility in the Netherlands}

Generally, researchers at WFBR analyse sorted products in a detailed way according to a wellestablished sorting protocol [Thoden van Velzen et al., 2018]. Since for this project, the main goal of the sorting procedure was to create washed milled goods with a high polymer purity, the following approach was defined. First everything was sorted on material type and main plastic type, by means of NIR technology. Second all targeted materials (rigid PE and PP objects) were divided into three categories of targeted packages types: bottles, flasks and other rigid packages. These last ones were selected as basis for further sample preparation. In total four samples of PP sorted product with a weight between 20 to $50 \mathrm{~kg}$ were analysed and five samples of PE sorted product with a weight between $35-60 \mathrm{~kg}$ were analysed. This analysis resulted in a composition of the targeted packages types (bottles, flasks and other rigid packages) per sorted product. This composition was compared to available model data [Brouwer, et al. 2019] to verify that the composition of the samples was representative for typical Dutch sorted products.

In order to reach a high polymeric purity of the PE and PP washed milled goods that were used as a base sample for this research, all other materials were manually removed from the packages. Only bodies, caps and labels of the targeted material were used as part of the sample. The targeted and removed parts are listed in Appendix A. The removed parts are distinguished between: caps, labels and removed packages or other items and parts with in-mould-labels or coatings (only for PP). Caps and labels of non-targeted materials were removed. Packages and other items were removed when it was impossible to remove the label completely, when the packaging was suspected to be made of a multi-layer material or when the package was contaminated with much product residue. All other objects with doubtful polymeric purity were removed as well. For PP specifically, also the packages with in-mould-labels or coatings were removed, as these labels and coating could be made of a different polymer than PP. 


\subsubsection{Mechanical recycling}

The PP and PE objects of high polymeric purity: bottles, flasks and other rigid objects without lids and labels of other polymers than the target material were mechanical recycled. This was executed for PE and PP separately, but the same protocol has been applied. It consists of the following steps:

1. Milling to $1-3 \mathrm{~cm}$ flakes with a WEIMA WLK-04 mill with a $35 \mathrm{~mm}$ screen plate. This was executed for the three PE packaging types (beverage bottles, non-beverage bottles and other rigid packages) separately, as for the two discerned PP packaging types (non-beverage bottles and other rigid packages).

2. Measuring the moisture content of samples of the five types of flakes using an oven and a balance.

3. Making ten sub-samples of $5 \mathrm{~kg}$ of PE flakes with a composition of $80 \%$ non-beverage bottles, $10 \%$ beverage bottles and $10 \%$ other rigid packages. Similarly making 10 sub-samples of 5 $\mathrm{kg}$ of PP flakes with a composition of $94 \%$ other rigid packages and $6 \%$ non-beverage bottles. Then continue the following steps for every $5 \mathrm{~kg}$ sub-sample separately. The relative proportions were roughly based on the output amounts of the mill (step 1).

4. Rinse/Pre-wash the sub-sample flakes with 150 litre of cold water. All the run-offs are sieved to collect the sludge.

5. Hot wash in alkaline solution $\left(>75^{\circ} \mathrm{C}, 0.01 \mathrm{M} \mathrm{NaOH}\right.$ for 5 minutes).

6. Rinse the flakes until the run-off has a pH value of less than 8.0.

7. Float-sink separation. Both PE and PP will float. This step is mainly included to remove packaging with additives or barrier layers.

8. Centrifuging for 2 minutes at $2000 \mathrm{rpm}$.

9. Thermal drying in an oven overnight at $105^{\circ} \mathrm{C}$ and measuring the weights of the main product (floating fraction), by-product (sinking fraction) and waste (combined sludge fractions).

10. Fine milling with a Wanner compact granulator $C 17.26 \mathrm{sv}$ and $8 \mathrm{~mm}$ sieve plate.

The mechanical recycling yields were calculated as previously described, using the recorded weights of the main product, by-product and dried sludges [Thoden van Velzen et al. $2016 \mathrm{~A}$ ].

\subsubsection{Matrix definition and preparation of samples with impurities}

Different impurities have been added to the pure rPP and rPE washed milled goods, to investigate the effect of the specific impurities on processing parameters and various material properties. To define a reasonable number of experiments and related measurements, a selection has been made of the type of samples that can be analysed during this project.

The impurities present in washed milled goods made from Dutch sorted PE and PP products were obtained from task 3 as main result. Based on these data, a selection was made of the most relevant impurities. Relevance was determined either by frequency of occurrence, quantity or expected impact of the impurity. Additionally, the perceptions of plastic recycling industry and packaging industry (tasks 1 and 2) was used to determine the most relevant impurities to take into account in this research. The percentage of impurity to add to the washed milled goods was also derived from data in task 3 , based on actual measured presence.

\subsubsection{1 rPP matrix definition}

In the described manner, the samples listed in Table 2.4 were defined and prepared for rPP. The table shows the description of the sample. Furthermore, also a picture of the added impurity is shown when available. Almost all samples were composed by adding the weight of the dry washed milled goods of the impurity to the dry washed milled goods of the pure rPP sample, before the extrusion process. Only the PET impurity was added as pellets during the extrusion process. When the impurity was derived from a sorting category of sorted products (post-consumer) an " $r$ " is used in front of the material name. Impurities from post-consumer waste were milled, washed manually and dried because the needed amount was very small (less than $100 \mathrm{~g}$ ). In case of in mould labels packaging 
(IML) as impurity, $5 \mathrm{~kg}$ of sample containing complete packages was mechanically recycled as described in 2.4.1.2. Clean samples such as Styrofoam packaging were only milled and added to the pure rPP.

Table 2.4 List of studied rPP samples including type and quantity of impurities.

\begin{tabular}{|c|c|c|}
\hline Sample code & Description & Picture of added impurity \\
\hline Ref 1 company 1 & Reference, $100 \%$ PP & Not applicable \\
\hline Ref 2 company 2 & Reference, $100 \%$ PP & Not applicable \\
\hline $100 \mathrm{rPP}$ & Reference, $100 \%$ rPP & Not applicable \\
\hline 2rHDPE & $2 \%$ HDPE flakes of clean rPE sample & \\
\hline 5rHDPE & $5 \%$ HDPE flakes of clean rPE sample & \\
\hline 10rHDPE & $10 \%$ HDPE flakes of clean rPE sample & \\
\hline 2rLDPE & $2 \%$ post-consumer LDPE (transparent film) & \\
\hline$\underline{0.5 P E T}$ & $0.5 \%$ PET granulate (Indorama N180) & \\
\hline 0.5PET - HT & $\begin{array}{l}0.5 \% \text { PET granulate (Indorama N180) - } \\
\text { high temperature processing }\end{array}$ & \\
\hline $0.5 \mathrm{PS}$ & 0.5\% PS (Styrofoam packaging, clean) & \\
\hline $0.5 r P V C$ & $\begin{array}{l}0.5 \% \text { post-consumer PVC packaging } \\
\text { material from sorted sample }\end{array}$ & \\
\hline 3.5rPPfilm & $3.5 \%$ post-consumer PP film & \\
\hline 0.5 rAlfilm & $\begin{array}{l}0.5 \% \text { Aluminium deposited flexible films } \\
\text { (post-consumer crisp bags) }\end{array}$ & \\
\hline
\end{tabular}



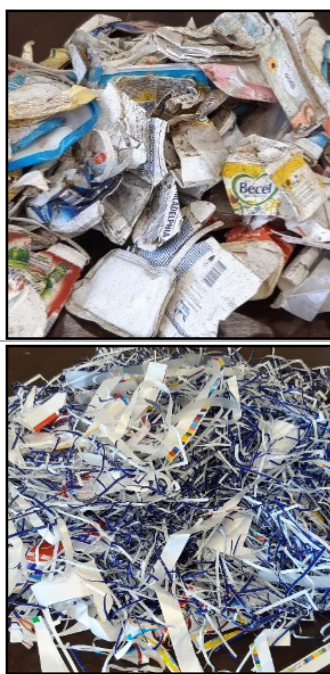

Reference materials (Ref 1 and ref 2 ) were supplied or purchased from two different companies. Ref 1 was the commercially available SABIC PP FPC70, nucleated and good antistatic performance with good flow behaviour (MFI of $70 \mathrm{~g} / 10 \mathrm{~min}$ ), and superior stiffness-impact balance (Charpy impact strength notched at $23^{\circ} \mathrm{C}, 7 \mathrm{~kJ} / \mathrm{m}^{2}$ ). It is typically used for high-speed injection moulding of rigid packaging or in caps and closures. Ref 2 was the commercially available Total Polypropylene PPR 10232 nucleated and antistatic random copolymer with a Melt flow Index of $40 \mathrm{~g} / 10 \mathrm{~min}$ and a Charpy Impact strength notched at $23^{\circ} \mathrm{C}$ of $6 \mathrm{~kJ} / \mathrm{m}^{2}$, for injection moulding applications of articles with high transparency and excellent surface appearance. Datasheets can be found in Appendix E.

\subsubsection{2 rPE matrix definition}

In a similar way as for rPP, representative samples have been defined for rPE. These are listed in Table 2.5. The table shows the description of the sample and (if available) a picture to show the type of material that has been added as impurity. All samples have been composed by adding the weight of the dry washed milled goods of the impurity to the dry washed milled goods of the clean rPE sample, so before the extrusion process. Most of the used impurities were milled, washed manually and dried before adding them to the base rPE. 
Table 2.5

List of studied rPE samples including type and quantity of impurities.

\begin{tabular}{|c|c|c|}
\hline Sample code & Description & Picture of added impurity \\
\hline Ref 1 & Reference, $100 \%$ PE & Not applicable \\
\hline 100rPE & Reference, $100 \% \mathrm{rPE}$ & Not applicable \\
\hline 2rPP & $2 \%$ PP flakes of clean rPP sample & \\
\hline 5rPP & $5 \%$ PP flakes of clean rPP sample & \\
\hline 10rPP & $10 \%$ PP flakes of clean rPP sample & \\
\hline 2rLDPE & $2 \%$ post-consumer LDPE (transparent film) & \\
\hline 5rLDPE & $5 \%$ post-consumer LDPE (transparent film) & \\
\hline 0.5 rPET & $0.5 \%$ post-consumer PET film (labels) & Not available \\
\hline $0.5 P S$ & $0.5 \%$ clean PS shrink film & \\
\hline $0.5 r P V C$ & $0.5 \%$ post-consumer PVC film & \\
\hline
\end{tabular}

Reference material (100PE) was the commercially available SABIC HDPE B5823, a typical blow moulding type with high stiffness environmental stress cracking. Melt flow rate of $0.89 \mathrm{~g} / 10 \mathrm{~min}$ at $190^{\circ} \mathrm{C}, 5 \mathrm{~kg}$ and an Izod impact notched of $12 \mathrm{~kJ} / \mathrm{m} 2$ at $23^{\circ} \mathrm{C}$. Datasheet can be found in the Appendix E.

\subsection{3 rPP processing and analysis}

Since PP is mainly used in injection moulding applications, it was decided to focus the analysis of the samples after processing on properties relevant for the processing and characterization of injection moulded products. A matrix was set where the sample variations are the rows and the analysis methods are indicated in the columns. The used reference matrix for the project can be found in Appendix B. Chosen measurements were done either on extruded pellets or in injection moulded bars. They are grouped in polymer melt flow tests (rheological properties), mechanical tests, colour tests and a larger group including physical, chemical and thermal analysis. Processability of the produced samples with different impurities plays an important role in the applicability of these materials, therefore special attention was paid to the processing parameters of the samples. 


\subsubsection{Extrusion process}

Samples prepared as described in section 2.4.2.1 were fed into a Berstorff ZE $25(\mathrm{CL}) * 40 \mathrm{D}$ extruder at a throughput of $5 \mathrm{~kg} / \mathrm{h}$. The extruder consists of $10+2$ zones, the last two are the coupling parts before the melt filter and after the melt filter and before the die, located at the end of the extruder. A scheme of the extruder from melt filter to feeding zone is given in Figure 2.6. The melt filter consists of two sieve holders that can be switched manually, this was done when the pressure before the filter reached 60 bar. A combination of two $3 \mathrm{~cm}$ diameter sieves was used: one fine of $250 \mu \mathrm{m}$ mesh size and one coarse of $400 \mu \mathrm{m}$ mesh size. The temperatures set up for each zone are given in Table 2.6. Vacuum extraction (degassing) was done towards the end of the extruder (Z10) to prevent foaming and remove volatile components. A $2 \mathrm{~mm}$ double hole die was used. Warm strands were cooled in a cold water bath and cut in a granulator at slow speed.

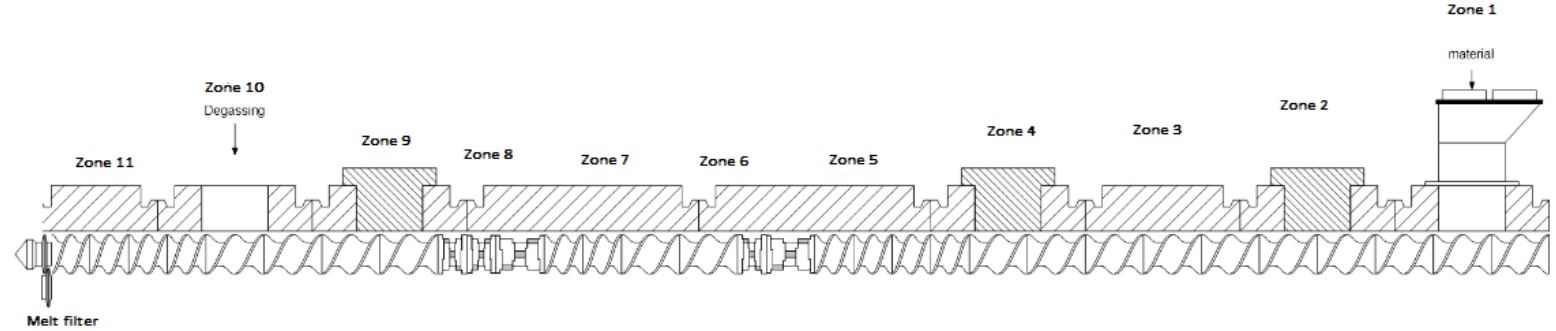

Figure 2.6 Schematic view of the extruder from melt filter (zone 11) to feeding (zone 1)

Table 2.6 Set temperatures at the extruder.

\begin{tabular}{|c|c|c|c|c|c|c|c|c|c|c|c|c|}
\hline & Z1 & $\mathbf{Z 2}$ & $\mathbf{Z 3}$ & $\mathbf{Z 4}$ & $\mathbf{Z 5}$ & Z6 & Z7 & $\mathbf{Z 8}$ & Z9 & Z10 & Z11 & $\mathrm{Z} 12$ \\
\hline $\begin{array}{l}\text { Temperature set } \\
\left({ }^{\circ} \mathrm{C}\right)\end{array}$ & - & 140 & 225 & 230 & 230 & 230 & 230 & 230 & 225 & 220 & 225 & 225 \\
\hline
\end{tabular}

\subsubsection{Injection moulding process}

Injection moulding was done in a Demag Ergotech 25-80 Compact machine. Tensile and impact moulds were used. Typical machine temperatures were $40 / 200 / 220 / 220 / 230^{\circ} \mathrm{C}$. Mould temperature was held constant at $30^{\circ} \mathrm{C}$. Injection times for tensile bars were 0.48 seconds for virgin materials and 0.49 seconds for all samples containing rPP. Impact bars had an injection time of 0.71 seconds for virgin materials and 0.72 seconds for samples containing rPP. Dosing times and injection pressures varied during processing, therefore they are reported in the processing results. Tensile and impact bars were produced in automatic mode.

\subsubsection{Polymer melt flow measurements}

MFI and rheometry measurements were done as described in 2.3.2.1. Temperature range of the rheometry measurements was different: these produced samples could be measured in the range 170 to $230^{\circ} \mathrm{C}$, closer to the melting and processing temperatures. Curves at different temperatures were combined in a master curve at $230^{\circ} \mathrm{C}$.

Spiral flow tests were performed in a Sumitomo Demag injection moulding machine type IntElect2 75/420-250 with the $18 \mathrm{~mm}$ screw. Temperature settings from feeding unit to mould were $50 / 200 / 220 / 230 / 230^{\circ} \mathrm{C}$. The mould temperature was held constant at $30^{\circ} \mathrm{C}$. Injection time was 5 seconds for all samples and the cooling time was 15 seconds. Dosing was done at $250 \mathrm{rpm}$ at a screw position of $85 \mathrm{~mm}$ and a pressure of 10 bar, during injection the speed was $60 \mathrm{~mm} / \mathrm{s}$ and the back pressure was 1000 bar. Samples were processed in semi-automatic mode, with exception of ref 2 that could be processed in automatic mode. An impression of the spiral flow mould and an injected moulded sample is shown in Figure 2.7. 

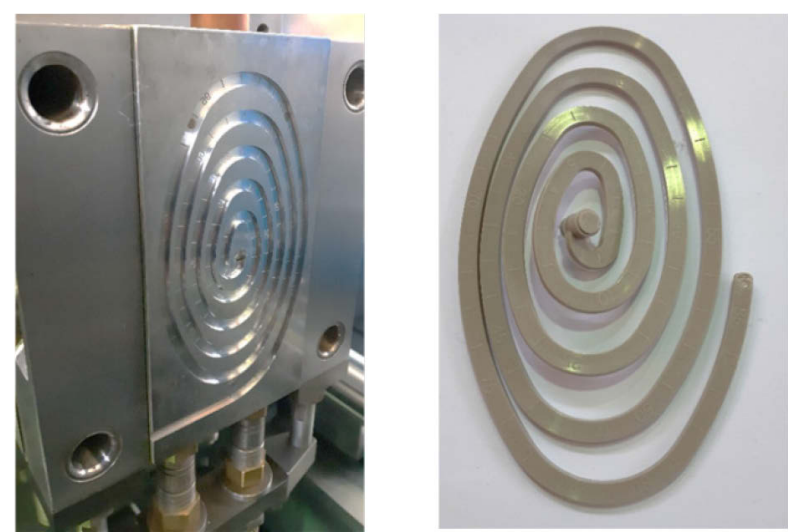

Figure 2.7 Spiral flow mould (left) and sample injected in this mould (right)

\subsubsection{Mechanical analysis}

Charpy impact strength unnotched and notched was measured according to ISO $179 / 1 \mathrm{eU}$ and ISO $179 / 1$ eA using a Ceast impact tester with a maximum energy of $4 \mathrm{~J}$. Samples were prepared as described in 2.4.3.2. Ten test bars per sample composition were conditioned and tested at $20^{\circ} \mathrm{C}$ and $50 \% \mathrm{RH}$. A schematic view of the impact tester is given in Figure 2.8.

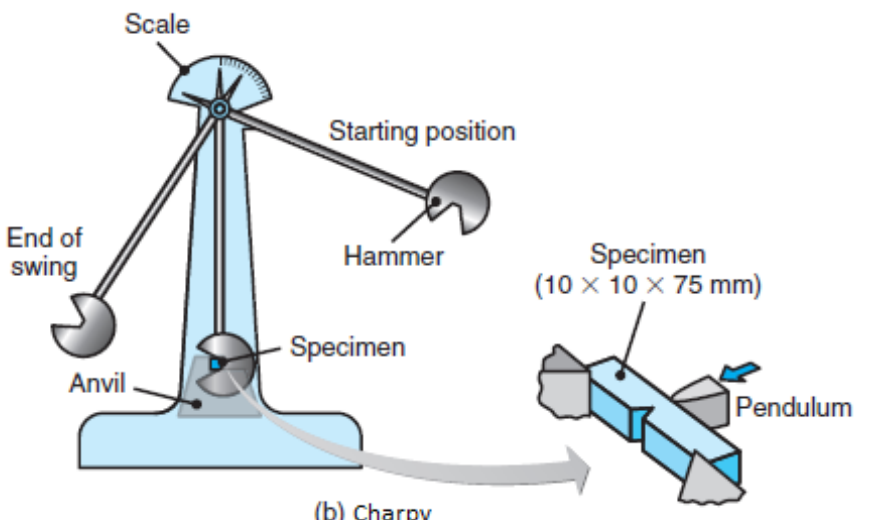

(b) Charpy

www.green-mechanic.com

Figure 2.8 Schematic view of a Charpy V-notch impact test (Green Mechanic, 2019)

\subsubsection{Physical, chemical and thermal analysis}

Density of the different polymers was measured by weighting around 1 gram of sample with an analytic balance and using a pycnometer $\mu$ ltraPYC1200e with nitrogen as gas to determine the volume of the weighted sample. The volume measurement was automatically repeated 5 times. One small piece of the injection moulded tensile bars was used for these measurements. The accuracy of the method is estimated to be around $1 \%$.

Thermal properties of the materials were measured by DSC as described in 2.3.2.2, for these samples additionally, samples were quenched by cooling them at $100^{\circ} \mathrm{C} / \mathrm{min}$ to $0^{\circ} \mathrm{C}$, held at $0^{\circ} \mathrm{C}$ for 5 minutes and additionally heated for a second time from 0 to $260^{\circ} \mathrm{C}$ at $10^{\circ} \mathrm{C} / \mathrm{min}$. For the analysis, the second heating curve was used. Here melting temperatures (peak maxima) of the found peaks, difference in enthalpy (area below the curve) and the calculated crystallinity of PP and amount of PE found in PP are reported.

DMTA was performed using a Rheometrics RSAII solids analyser using a tensile fixture test setup. It was performed on injection moulded tensile bars on a temperature range from 0 to $180^{\circ} \mathrm{C}$ at $5^{\circ} \mathrm{C} / \mathrm{min}$.

Fourier transform infrared (FT-IR) spectra was performed on the pellets on a Bruker Alpha II FT-IR spectrometer equipped with a DTSG-detector. The measurement resolution was set at $4 \mathrm{~cm}^{-1}$, and the spectra were collected in the range $4000-400 \mathrm{~cm}^{-1}$ for attenuated total reflectance (ATR) with $50 \mathrm{co-}$ added scans. The sample chamber was purged by $\mathrm{N}_{2}$ gas for $10 \mathrm{~min}$ before scanning was started. 


\subsubsection{Colour characterization}

Colour was measured as described in section 2.3.2.3 on impact bars. The colour parameters were combined in one comparative number: $\Delta \mathrm{E}=\left[\left(\Delta \mathrm{L}^{* 2}\right)+(\Delta \mathrm{a} * 2)+\left(\Delta \mathrm{b}^{* 2}\right)\right]^{1 / 2}$, the average of the 2 samples made of $100 \%$ rPP was used as the reference value.

\subsection{4 rPE processing and analysis}

Since PE is mainly used in extrusion applications, it was decided to focus the analysis of the samples after processing on properties relevant for the processing and characterization of extruded products. A similar matrix to the one set up for rPP was described for rPE where the sample variations are the rows and the analysis methods are indicated in the columns. The used reference matrix for the project can be found in Appendix B. Chosen measurements were done either on extruded pellets, injection moulded impact bars or extruded sheets. They are grouped in polymer flow tests, mechanical tests, colour tests and a larger group including physical, chemical and thermal analysis. Processability of the produced samples with different impurities plays an important role in the applicability of these materials, therefore special attention was paid to the pellet and sheet extrusion processing parameters of the samples.

\subsubsection{Extrusion process}

Samples prepared as described in section 2.4.2.2 were fed into a Berstorff ZE $25(\mathrm{CL}) * 40 \mathrm{D}$ extruder at a throughput of $5 \mathrm{~kg} / \mathrm{h}$. The same extruder as described in 2.4.3.1. The temperature profile used is given in Table 2.7. The melt filter was replaced manually when the pressure before the filter reached 105 bar. The amount of times the melt filters had to be replaced was recorded.

Table 2.7 Set temperatures at the extruder for rPE.

\begin{tabular}{llllllllllllll} 
& $Z 1$ & $Z 2$ & $Z 3$ & $Z 4$ & $Z 5$ & $Z 6$ & $Z 7$ & $z 8$ & $z 9$ & $Z 10$ & $Z 13$ & $Z 14$ \\
$\begin{array}{l}\text { Temperature set } \\
\left({ }^{\circ} \mathrm{C}\right)\end{array}$ & - & 140 & 230 & 235 & 235 & 235 & 235 & 235 & 230 & 230 & 235 & 235 \\
\hline
\end{tabular}

\subsubsection{Injection moulding process}

Injection moulding was done in a Demag Ergotech 25-80 Compact machine. Impact bars moulds were used. Typical machine temperatures were $25 / 220 / 230 / 235 / 240^{\circ} \mathrm{C}$. Mould temperature was held constant at $30^{\circ} \mathrm{C}$. Injection times were 0.73 seconds for all materials. Dosing times and injection pressures varied during processing, therefore they are reported in the processing results. Impact bars were produced in automatic mode.

\subsubsection{Sheet extrusion process}

Sheets were extruded in a Dr. Collin Teachline E20T extruder with a $15 \mathrm{~cm}$ width sheet die at a throughput of $2 \mathrm{~kg} / \mathrm{h}$. Screw speed was kept constant at $90 \mathrm{rpm}$. The sheets were transported from the die through a Haake calender with warmed rolls at a temperature of $30^{\circ} \mathrm{C}$ and $20 \%$ of the maximum speed. Set temperature of the teachline is shown in Table 2.8. At the end of the extruder, just before the die a similar filtration system as the one used for extrusion is placed. Sheets were produced at a thickness between 650 and $700 \mu \mathrm{m}$.

Table 2.8 Set temperatures at the sheet extruder.

\begin{tabular}{|c|c|c|c|c|c|c|c|c|}
\hline & $\mathrm{T} 1$ & $\mathrm{~T} 2$ & T3 & T4 & T6 & T7 & T8 & T9 \\
\hline & $\begin{array}{l}\text { Extruder } \\
\text { Feed zone }\end{array}$ & \multicolumn{3}{|c|}{ Extruder melting zones } & $\begin{array}{l}\text { Extruder zone } \\
\text { before die }\end{array}$ & Die middle & Die Right & Die Left \\
\hline Temperature set & 60 & 228 & 238 & 243 & 248 & 248 & 254 & 256 \\
\hline
\end{tabular}




\subsubsection{Polymer melt flow measurements}

MFI and rheometry measurements were performed as described in 2.3.2.1. Temperature range of the rheometry measurements was different: these produced samples could not be measured in a range of temperatures and therefore, measurements were only done at $250^{\circ} \mathrm{C}$.

\subsubsection{Mechanical analysis}

Notched Charpy impact strength was measured according to ISO 179/1eA using a Ceast impact tester with a maximum energy of 4 J. Samples were prepared as described in 2.4.4.2. Five test bars per sample composition were conditioned and tested at $20^{\circ} \mathrm{C}$ and $50 \% \mathrm{RH}$. The average values and corresponding standard deviations were calculated and reported.

rPE sheets were tested for tensile strength properties using a Zwick Z010 all-round line 10kN mechanical testing machine according to ISO 527-1, at a test speed of $1 \mathrm{~mm} / \mathrm{min}$ to determine the Emodulus and $100 \mathrm{~mm} / \mathrm{min}$ for the elongation at break and the maximum stress. Samples were cut with a mould from the extruded sheets.

Falling dart impact testing was performed on a Rosand falling weight impact tester according to ISO 7765 using a weight of $4.5 \mathrm{~kg}$ and a height of $1 \mathrm{~m}$. Tests were performed with the extruded sheet. The obtained forces were corrected for the sheet thickness $(\mathrm{J} / \mathrm{mm})$. The test results of five measurements were averaged and reported.

\subsubsection{Physical, chemical and thermal analysis}

Density of the different polymers was measured as described in 2.4.3.5. One small piece of the injection moulded tensile bars was used for these measurements. Measurements were done in twofold.

Thermal properties of the materials were measured as described in 2.3.2.2, for these samples additionally, samples were quenched by cooling them at $100^{\circ} \mathrm{C} / \mathrm{min}$ to $0^{\circ} \mathrm{C}$, held at $0^{\circ} \mathrm{C}$ for 5 minutes and additionally heated for a second time from 0 to $260^{\circ} \mathrm{C}$ at $10^{\circ} \mathrm{C} / \mathrm{min}$. For the analysis, the second heating curve was used. Here melting temperatures (peak maxima) of the found peaks, difference in enthalpy (area below the curve) and the calculated crystallinity of PE are reported.

Fourier transform infrared (FT-IR) spectra was performed on the pellets as described in 2.4.3.5.

\subsubsection{Colour characterization}

Colour was measured using Konica Minolta Chroma meter CR-400 according to the CIELAB method on impact bars. As background reference a white tile was used. Method used was described in 2.4.3.6 


\section{Perceptions of the plastic recycling industry}

The plastic recycling industry that processes post-consumer sorted PE and PP is heterogeneous in multiple aspects, such as feedstocks, products, quality policies, size and level of integration. It is therefore not surprising that representatives of this industry have different opinions on the standardisation of recycled plastic products. Conversely, these representatives did agree on recent developments, opportunities and threats for their businesses.

\subsection{Current practices}

\subsubsection{Feedstock}

A minority of the interviewed companies exclusively use sorted post-consumer packaging waste as feedstock. In the case of these PE and PP recycling companies either DKR 329 or DKR 324 is used. Most of the interviewed companies use mixtures of post-consumer sorted plastics, post-industrial sorted plastics and sorted municipal plastic waste as feedstock. ${ }^{2}$ All recycling companies source their sorted PE and PP materials from multiple countries and collection systems. Besides stable supply relations with sorting companies, most have also flexible trading relations with sorting companies. The quality of the feedstock is a major concern for all recycling companies. Roughly $10-40 \%$ of the sourced feedstock does not comply with the specifications (DKR 329 and 324). A minority of the recycling companies analyses all the incoming feedstock lots. Most of the recycling companies only check the quality of new suppliers and in case of problems and anomalies during recycling. The prime reason for the incomplete check on the feedstock is the high labour costs involved with these quality checks. Only one company rejects non-compliant sorted material and returns it. Most recycling companies use these non-compliant feedstocks for different products or dilute it with less impure feedstock.

Recycling companies have different opinions on impurities in the feedstock. Recycling companies that produce demanding products, such as consumer articles and packages, supplied us with detailed lists of impurities that disturb their production processes and need to be controlled in the feedstock and/or removed during processing. Whereas other recycling companies state that there are no impurities of real concern for their products, as they remove the unwanted materials in their recycling process.

The impurities in sorted PP (DKR 324) that were named as challenging by several companies are listed below. These impurities result in particle contamination in the rPP:

- Top-seal films of trays and lids (sources of Aluminium, PA, EVOH, PET, etc.),

- Glue residues,

- Silicone rubber objects, such as valves,

- Metal springs,

- $\quad$ Objects and packaging components made from PET, PS, POM, PLA, ABS, labels and sleeves.

Furthermore, recycled PP always contains PE that originates both from sorting mistakes and from packaging components. This PE also forms polymeric contamination in the recycled PP, but its presence deteriorates the quality of the recycled PP to a lesser extent than the other polymers named above. However, in case the PE share exceeds $20 \%$, the processing of rPP becomes more difficult. At these high concentrations of PE, the MFI (melt flow index) cannot be lowered anymore with peroxides to tune the rPP to the correct melt viscosity for injection moulding. Finally, film material was named as impurity that occasionally causes problems when it is present in larger shares; this is often PE or PP

\footnotetext{
${ }^{2}$ Within the Dutch context municipal plastic waste is what civilians drop-off as plastic waste at municipal collection centers, which is mostly a mixture of non-packaging plastics (household utensils, toys, building \& construction plastics, etc.).
} 
based and influences the melt viscosity of rPP and also is a possible cause of polymeric contamination (PE).

The impurities that occur in rPE (DKR 329) and that were named as challenging by the recycling companies were the following:

- Paper and wood,

- Silicon kit tubes,

- Glue residues from labels and hotmelt,

- $\quad$ PET, PS, POM, ABS, PLA and different labels and sleeves,

- Too high levels of PP (roughly above 15\%)

\subsubsection{Processes}

Most recycling companies have a standard mechanical recycling process with the following process steps: quality control feedstock, milling, washing, sink-float-separation, drying, milling, extrusion with vacuum de-odourisation. Nevertheless, they all have variations (process throughput time, temperatures, surfactants, rinsing, de-metallisation, melt filtration mesh). The most prominent difference that impacts the final product quality the most, is flake-sorting. Flake-sorting (NIR, colour, laser) is an end-of-process-solution to create more homogeneous products in colour and polymeric composition, but usually at the expense of either a more impure by-product that needs to be dealt with or relatively high costs. The flake-sorting technique and engineering is relatively new (less than 10 years) and is not yet used by all recycling companies. However, several recycling plants do use this technique to market more pure and valuable recycled plastics.

\subsubsection{Products}

The recycling companies of PE and PP produce varying products. Most trade compounds (compounded pellets ready for a certain applications, for example blends of recycled plastic with virgin polymer or additives), some pellets of recycled plastic and some trade plastic objects made from the recycled plastics. None of the companies trade washed milled goods. This relates to the added-value of the products, which is almost absent for washed milled goods, slightly better for pellets without additives, but it can be significant for compounds and it is usually substantial for finished plastic objects.

The compounds are aimed at certain processing technologies (extrusion, injection moulding) and are often multi-purpose compounds; from which multiple objects can be made with the same processing technology and compounds. Only a few compounds are truly aimed for the production of one specific product or even at one specific client. The typical final products which are made from these compounds are currently:

- rPE extrusion products such as: non-food bottles, cable lining, tubes, mortar tubs, construction buckets, construction road plates, etc.

- rPP injection moulding products such as: flower pots, automotive parts, electronic appliances, paint pots, waste containers, garden furniture, crates, drainage elements, various consumer articles, etc.

The recycled PE and PP products are sold with technical data sheets that are aimed at their intended application. In general these datasheets include: MFI, colour parameters, density, ash content, residual moisture content, mechanical properties such as E-modulus, tensile strength and Charpy notched impact. The vast majority of the products sold have a recycled content of $100 \%$, and a minority of the products is a mixture of recycled content and virgin plastic. Nevertheless, the small amounts of additives and fillers that are added, are predominantly not based on recycled content.

\subsection{Business barriers}

For the majority of the recycling companies it is a continuous challenge to sell their products. Only one recycling company stated that they have no issues at all selling their recycled plastics, but that sourcing sufficient amounts of quality feedstock was their prime concern. Remarkably this company 
has the most strict quality control system for feedstock and is an integrated part of a larger plastic industry.

The recycling companies that report issues with selling their products, also named the barriers which they experience when serving clients. None of these barriers relate to technical requirements. In almost all cases, the plastic recyclers can create products based on recycled plastics that comply to technical demands such as E-modulus, etc. The barriers for the uptake of recycled plastics are discussed in the following paragraphs.

\subsubsection{Avoid potential risks}

Many producers seem to avoid potential risks by explicitly stating in their procurement specifications that the material should be virgin, without any technical or legal base. This is common for durable construction plastics, housing of electrical appliances, waste containers, paint pots, jerry cans for chemical waste, etc. In the market for cosmetic packaging, plastics often have to comply to the food contact material legislation, although cosmetics are obviously not a food product. The consequence is then that only virgin plastics qualify.

\subsubsection{Optical properties}

Optical properties such as colour and gloss can limit the applicability in almost all application fields. In the field of packaging, the precise colour of a bottle or tray is a valuable asset of the brand and closely guarded. Many marketers do not accept slightly varying levels of colour and gloss and they can achieve a stable colour and gloss only by limiting the recycled content. It is only a recent development to use recycled plastics in packages with 'natural colours' and 'varying colours'. For the majority of the non-food packaging markets this is still a very real barrier, especially when transparent plastics are demanded.

\subsubsection{Odour}

Odour is another barrier for the use of recycled plastics in applications such as cosmetics packaging, appliances housing and household utensils. Although the odour of recycled plastics can be limited, several typical odorants cannot be removed completely. Hence the use of recycled plastics for odoursensitive applications remains a real barrier.

\subsubsection{Legislation}

Many producers demand that plastic feedstocks comply with the European REACH legislation and this is very challenging for recycled plastics due to its chemical nature. ${ }^{3}$ This can only be resolved by more clear legislation aimed for recycled plastics.

\subsubsection{General business issues}

The prime focus of the recycling industries is assuring feedstock with sufficient quality in sufficiently large amounts, implying sorted products that comply with the current specifications. Their second focus is enlarging the market for recycled plastics and removing business barriers. As explained above the nature of these barriers is manifold; from legal obstacles to marketing requirements. Most recycling companies agree that creating technical standards for recycled products might help to convince clients to choose for recycled plastics.

Some of the barriers relate to governmental policies. The recycling companies note that virgin plastics are still relatively cheap and it is challenging to produce recycled plastic for a competitive price. The

\footnotetext{
${ }^{3}$ A complete explanation of the complicated legal situation of recycled plastics with respect to REACH can be found at: Römph \& Van Calster RECIEL. 2018;27:267-277
} 
price gap between virgin and recycled plastics is relatively small. Recent developments such as rising energy prices and incineration gate fees (for waste streams of the recycling plants) have reduced this price gap even further. Policies that would reduce the price gap could help recycling companies. Furthermore, the recycling industries would be helped by creating a legal framework for recycled plastics to comply with the REACH legislation. 


\section{Perceptions of the packaging industry}

Recycled PE and PP are currently only used in non-food-packages. Mostly in bottles and flasks, some in rigid packages such as tubs and jars and some in caps and closures. Typical products that are packed with recycled content (rPE or rPP) include: household chemicals, detergents, personal care products, cosmetics and secondary packages (crates, pallets). The users are experiencing multiple barriers when considering the use of recycled content for their packages. Their motivation and the experienced obstacles are discussed below.

\subsection{Motivation}

The prime motivation of FMCG manufacturers to use post-consumer recycled PE and PP in their packages is to reduce the environmental impact of their product-packaging-combinations. In a few cases their clients (retail organisations) have either explicitly asked for packages with recycled content or more in general have asked the company to reduce the environmental impact of their productpackaging-combinations. Most manufacturers regard using recycled content as one of the options to reduce the environmental impact. Other options considered are: material reduction, bio-based materials, improving the recyclability, redesign to different materials, overall redesign of the product to allow the packages to be downsized or even avoided. For each product-packaging-combination the options are typically evaluated for technical feasibility, costs, expected environmental impact and marketing impact. Depending on the packaging policies of the company the most suited option is selected. Some companies name the negative debate on plastics as a driver for their actions towards recyclable packages and the use of recycled content in their packages.

\subsection{Barriers}

The users experience multiple barriers when using rPE and rPP recycled content in their packages. Most barriers were named by multiple companies and are clearly shared experiences. Some experiences are unique anecdotes and only a few are contradicting between the companies. Therefore, this description of the barriers is a rough generalisation with a focus on the shared barriers.

\subsubsection{Maturity of the recycling industry}

The plastic recycling industry is often compared to the virgin plastic industry by FMCG-manufacturers as they perceive them as competing feedstock suppliers. However, the recycling industry is much smaller in size than the virgin plastic industry. Which implies that less brands and types are available from less companies. Especially for rPP the amount of recycling companies is limited, since it is sorted and recycled in only a limited amount of countries. Additionally, due to the nature of the mechanical recycling process which can currently not discriminate between polymer grades, also limited grades of recycled plastics can be produced. A normal sized recycling industry will produce 25 kton per annum and large ones will approach 100 kton per annum, which is obviously much smaller than the production numbers of virgin plastic suppliers which range in the megatons. Such scale differences tend to affect the level of professionalism that companies can offer on many levels (client support, supply logistical options, laboratory tests, etc.). Nevertheless, within the rPE and rPP recycling industries we have seen a rapid professionalisation in the last decade. Whereas ten years ago some recyclers would qualify as back barn activities, nowadays, these companies have professional sales departments and laboratories that can perform standardised measurements and assist new clients with application tests. Furthermore in recent years, multiple recycling companies have been purchased by larger plastic industries and conglomerates (QCP and Lyondell-Basell, MTM and Borealis, Prezero and Lidl/Kaufland, AKG and Veolia) adding to their maturation and professionalism.

Although the production capacities of the European recycling industries are annually growing and more recycled plastics are becoming available each year, larger enterprises find it difficult to procure 
sufficient large amounts of plastic materials for their packages. In order to produce their packages in a reliable and controllable manner, this recycled plastic feedstock needs to comply to multiple technical parameters. For every packaging application there is a different set of requirements. Since larger enterprises typically need kilotons of plastics even for their smallest products, their problem is procuring these different, highly specific, qualities of recycled plastics in sufficiently large amounts. For smaller enterprises, which typically need smaller amounts of feedstock, this is obviously a less relevant issue.

\subsubsection{Quality issues}

\subsubsection{Food safety}

The main quality issue that limits the use of rPE and rPP is food safety, as these recycled plastics are currently not available for food applications. This confines the applications to roughly one-third of the packaging market. Several of the FMCG manufacturers would want to use rPE and rPP in food packages, when food safe rPE and rPP would become available. Furthermore it has secondary effects. Many packaging markets (personal care products, cosmetics) do not yet have precise regulations for migration. As a consequence, some companies fill that legal void by demanding food-grade qualities for their packages as a general safety precaution. This limits the market for recycled plastic even further. Secondly, several plastic converters produce packages both for food and non-food-markets and hence have to comply to HACCP regulations which limits the presence of non-food-grade materials in the production venue. Those multi-purpose converters are therefore not allowed to work with nonfood-grade recycled plastics, which usually implies that they only work with virgin plastics.

\subsubsection{Odour}

Odour is a next quality issue, related to migration. Users indicate that odour issues with rPE are usually more severe than with rPP, but nevertheless both can have a smell, that ranges from 'fresh cleaning agents' to musty and even noxious. These smell issues are a problem both during processing and in the finished products. In some cases the odours are subtle but still not fitting with the packaged product; the producer of a luxurious cosmetic doesn't want the package to smell like a cheap cleaning agent. One anecdote reports of new undesired odours being formed due to an interaction between the product and the recycled plastic package. In other cases the odour was unbearable. In an anecdote a warehouse with mortar tubs made from low quality rLDPE had to be evacuated and aired out due to the intense stale smell. Odours of recycled plastic are hence an important aspect that can limit its applicability, especially in personal care products.

\subsubsection{Colour}

Most FMCG manufacturers want to control the colour of their packages strictly; the colour is for them an important marketing aspect. For those type of manufacturers, colour imperfections and variations in colour between different batches are absolutely unacceptable. However, always producing exactly the same type of colour is difficult for recycling industries, due to relative large variations in feedstock. Furthermore, the colours 'transparent' and white remain challenging colours to achieve with recycled plastics. Several FMCG manufacturers and retailers are open to using a grey recycled plastics and use a masterbatch to provide the desired colours, however the final colour of the packaging should always be the same. This level of stability is hard to achieve for the recycling industry. Some FMCG manufacturers and retailers have understood this large colour-challenge for recycled plastics and have agreed to use varying colours. Recently the company RB joined this group of manufacturers with a rPP box for washing pods with a dull dark green finish and clearly communicating that the box is produced from rPP [RB, 2019]. This new box misses the gloss of the previous box made from virgin glossy green PP, but is positively marketed as a more environmental friendly package and this message is reconfirmed by the dull colour of the box. This could be regarded as a paradigm change; grey, natural and dull colours as an expression of eco-friendly recycled plastics. This paradigm change is happening within society and the FMCG manufacturers and its progress will alleviate the applicability of recycled plastics. 


\subsubsection{Quality variations}

Packaging producers require a polymer with stable technical parameters within small tolerances. Dimensional stability and colour (see 4.2.2.3) were mentioned as important quality parameters that are known to vary.

\subsubsection{Processability}

Besides, the issues regarding quality, there are many different technical parameters that recycled plastics will need to comply to and these vary per application. Rather common technical parameters are E-modulus, tensile strength, Charpy notched impact, dimensional stability, etc. Most FMCG manufacturers and retailers outsource the processing of their packages, and are thus not aware of the specific technical details of these processes. However, most of the users of rPE did not encounter problems with the mechanical properties of the recycled products that they used, and are thus currently on the market.

Obviously, all plastics need to be processed in their converting machines and these operations should run smoothly and not cause variations and instabilities. Virgin plastics are often tailor-made for certain converting technologies and hence they typically run smoothly on the machines they were designed for. Recycled PE and PP are made of mixtures of grades and contain impurities. According to company representatives, the MFI of rPE is usually fairly constant between batches. However, processing settings still need to be adjusted with every batch, probably due to differences in the complex viscosity. Recycled PP is known to be a mixture of a wide variety of grades which results in less predictable processing behaviour and other properties like melt flow, stiffness and impact resistance. Although issues with the processability of recycled PE and PP are becoming less common with the increased maturation of the recycling industry, it remains an additional aspect that needs to be monitored and controlled.

\subsubsection{Better safe than sorry}

General safety precautions make it difficult to use recycled plastics for household chemicals. Household chemicals with relatively high risks associated with them are still packed in bottles from virgin PE instead of $\mathrm{rPE}$, such as chlorine bleach products, insecticides and herbicides. Using recycled plastics is still regarded as a too large liability risk by the producers. Furthermore, the permits for marketing crop protection agents, including the household variants, describe the package in which the product can be distributed and these are hitherto always virgin plastics.

In reflection, there are still several barriers in proceeding towards a more circular economy for plastic packages, relating to quality issues, legal affairs and business practises. The issues raised by both groups of industry representatives confirm the limitations of the produced recycled materials and their use in high value applications. 


\section{Analysis of current quality of recycled PP and PE}

The aim of this chapter is to describe the quality of recycled PP and PE products that are currently on the market. Several recycling plants provided their products for analysis in this project: flakes and/or extruded pellets. Both are discussed in separate sections.

\subsection{Flakes}

\subsubsection{Analysis of rPP flakes}

The measured polymeric composition of the rPP flakes, provided by different companies, is schematically shown in Figure 5.1 and the measured data is listed in Table 5.1. The industrially made rPP flake product samples were obtained from two different recycling industries with sorted product PP (DKR 324) as feedstock. The different origins as described in section 2.3 are indicated with two different colours (blue and green) in Figure 5.1.

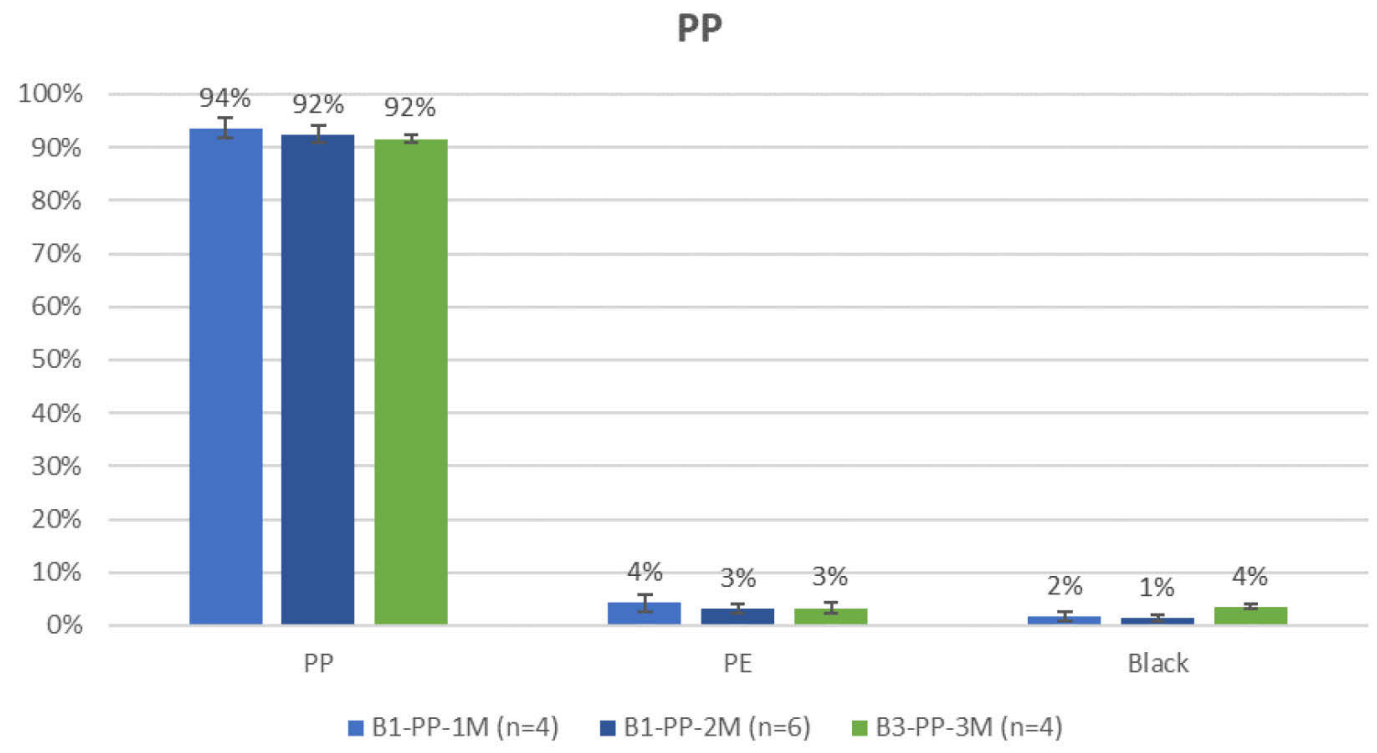

Figure 5.1 Polymeric composition of recycled PP flakes from two different recycling
companies, the colours refer to different companies

Industrially produced washed milled goods made from sorted PP (DKR 324) are roughly composed of 92-94\% PP flakes, 3-4\% of PE flakes, 1-4\% black plastic flakes and sub-percent amounts of PET, PS and PVC. The black plastic flakes are most likely also mainly made from PE and PP, since the recycling processes involve sink-float separation and therefore the sinking polymers are removed.

Other polymers, such as PMMA and PC are only occasionally present in the washed milled goods and at very low concentrations. Possibly also other polymers might occur in these washed milled goods haphazardly at low concentrations, as observed for PMMA and PC in these samples.

Other materials found in the washed milled goods are textile, wood, aluminium and paper. Aluminium was present in all samples at concentrations between 0.1 and $0.4 \%$. Most of the aluminium objects were based on aluminium foil and derived flexible products. Paper, wood and textile only occurred haphazardly at low concentrations. The only exception was textile. It was found in a $1.7 \pm 1.3 \%$ concentration in only one sample. Much more samples will need to be studied to establish whether or not this is an outlier or a normal concentration at which textile impurities vary in PP flakes. 
In summary, industrially produced post-consumer PP flakes are composed of mostly PP (92-94\%) and some PE (3-4\%) and usually sub-percent amounts of minor impurities. The latter are both other polymers (PET, PS, PVC, PMMA, PC) and other materials (paper, wood, aluminium, textile). Some of the minor impurities are always present at sub-percent levels (PET, PS, PVC, Aluminium) and other impurities are sporadically present (PMMA, PC, wood, paper, textile).

Table 5.1 Material composition of the recycled PP flakes from three different recycling companies.

\begin{tabular}{|c|c|c|c|}
\hline Polymers / Materials & B1-PP-1M $(n=4)$ & B1-PP-2M $(n=6)$ & B3-PP-3M $(n=4)$ \\
\hline PP & $94 \%$ & $92 \%$ & $92 \%$ \\
\hline PET & $0.01 \%$ & $0.1 \%$ & $0.4 \%$ \\
\hline PVC & $0.02 \%$ & $0.2 \%$ & $0.1 \%$ \\
\hline Black & $2 \%$ & $1 \%$ & $4 \%$ \\
\hline PMMA/PES? & $0.005 \%$ & & \\
\hline Wood & & $0.01 \%$ & $0.1 \%$ \\
\hline Textile & & $1.7 \%$ & \\
\hline
\end{tabular}

\subsubsection{Analysis of rPE flakes}

The measured polymeric composition of the rPE flakes is schematically shown in Figure 5.2 and the measured data is listed in Table 5.2. The industrially made rPE flake product samples were obtained from three different recycling industries with sorted product PE (DKR 329) as feedstock. We received in total seven different samples of rPE washed milled goods. These seven different samples are indicated with three different colours (blue, green and orange) to differentiate the origins (recycling facilities) in Figure 5.2.

PE

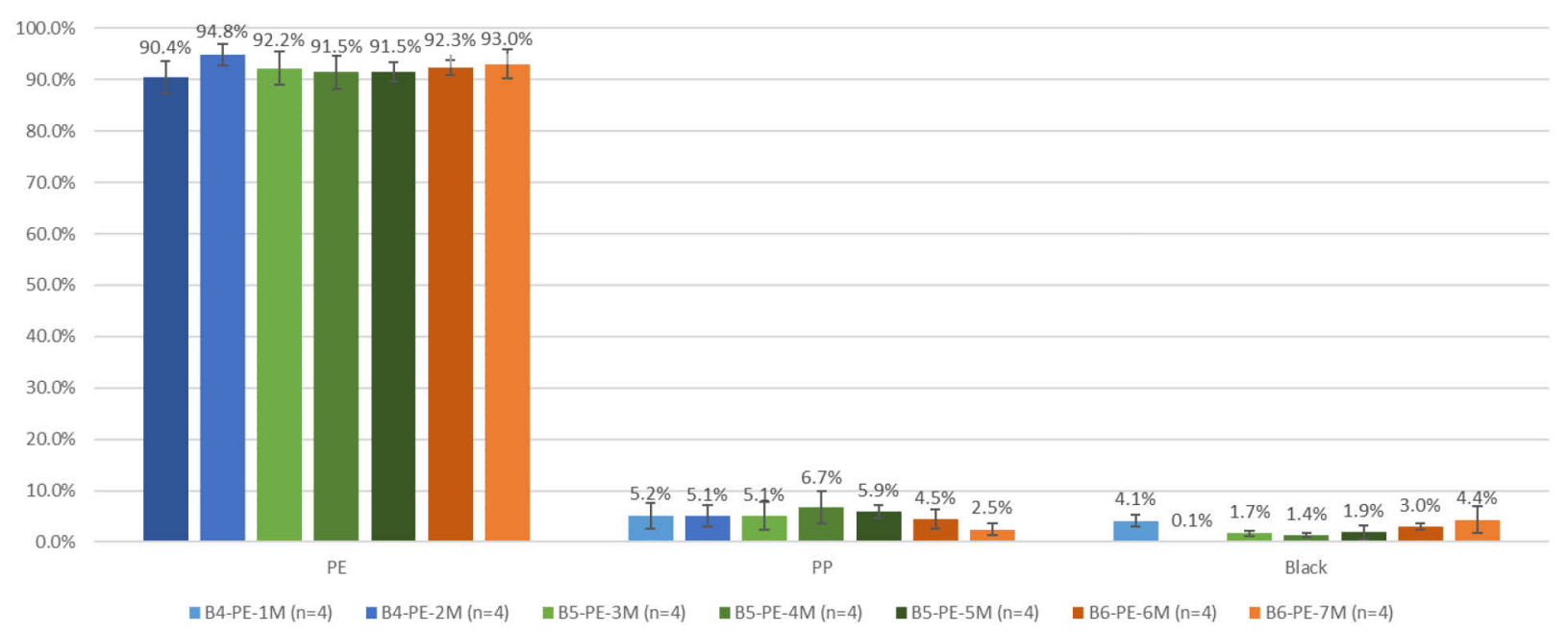

Figure 5.2 Polymeric composition of recycled PE flakes from three different recycling companies, the colours refer to seven different samples obtained from these three companies 
The industrially recycled post-consumer PE flakes consist of 90-95\% PE, 2-7\% PP, 1-4\% Black and several sub-percent impurities. Of these, most were polymeric impurities. PS was present in all samples at concentrations of $0.03-0.3 \%$. PET and PA were present in more than half of the samples in concentrations of $0.004-0.2 \%$ and $0.1-0.2 \%$, respectively. Only in one sample PC was found at $0.01 \%$. The black plastic is likely to be mainly either PE or PP, since the industrial processes all involve a sink-float-separation step to remove the sinking fractions like PET. Only one sample had a very low concentration of black plastic flakes of $0.1 \%$, since this sample was sold as "ivory quality" which means colour-sorted. No PVC was found in any sample of rPE flakes.

Table 5.2 Material composition of the recycled PE flakes from seven samples of three different recycling companies.

\begin{tabular}{|c|c|c|c|c|c|c|c|}
\hline & $\begin{array}{c}\text { B4-PE-1M } \\
(n=4)\end{array}$ & $\begin{array}{c}\text { B4-PE-2M } \\
(n=4)\end{array}$ & $\begin{array}{c}\text { B5-PE-3M } \\
(n=4)\end{array}$ & $\begin{array}{c}\text { B5-PE-4M } \\
(n=4)\end{array}$ & $\begin{array}{c}\text { B5-PE-5M } \\
(n=4)\end{array}$ & $\begin{array}{c}\text { B6-PE-6M } \\
(n=4)\end{array}$ & $\begin{array}{c}\text { B6-PE-7M } \\
(n=4)\end{array}$ \\
\hline PE & $90.4 \%$ & $94.8 \%$ & $92.2 \%$ & $91.5 \%$ & $91.5 \%$ & $92.3 \%$ & $93.0 \%$ \\
\hline PP & $5.2 \%$ & $5.1 \%$ & $5.1 \%$ & $6.7 \%$ & $5.9 \%$ & $4.5 \%$ & $2.5 \%$ \\
\hline PET & $0.004 \%$ & & $0.5 \%$ & $0.2 \%$ & $0.3 \%$ & & $0.005 \%$ \\
\hline PS & $0.1 \%$ & $0.01 \%$ & $0.3 \%$ & $0.03 \%$ & $0.1 \%$ & $0.04 \%$ & $0.2 \%$ \\
\hline Black & $4 \%$ & $0.1 \%$ & $2 \%$ & $1 \%$ & $2 \%$ & $3 \%$ & $4 \%$ \\
\hline PA & $0.1 \%$ & & $0.1 \%$ & & $0.2 \%$ & $0.1 \%$ & \\
\hline PC & & & & & & & $0.01 \%$ \\
\hline Aluminium & & & $0.1 \%$ & $0.2 \%$ & $0.1 \%$ & & $0.01 \%$ \\
\hline Wood & & & & $0.02 \%$ & $0.1 \%$ & & \\
\hline Textile & $0.005 \%$ & & & & & & \\
\hline
\end{tabular}

The impurities from other materials occur haphazardly in the rPE flakes. The most common was aluminium, present in 4 of the 7 samples at concentrations between $0.01-0.2 \%$. Wood was present in only two of the seven samples at concentrations of $0.02-0.1 \%$. Textile was present only in one sample at $0.005 \%$.

\subsubsection{Model analysis on origin of impurities}

The impurities in the washed milled good can originate from targeted packages (packaging design) and from faulty sorted objects of a different polymer type (sorting mistake). The data was analysed with a MFA model to find the most likely origin of the impurities (model is described in section 2.3.3). In the PE washed milled good roughly $80 \%$ of the polymeric impurities originate from the PE packages itself, and thus roughly $20 \%$ are a result of other, faulty sorted products. In the PP washed milled goods this is reversed: $15-20 \%$ originates from the PP packages, and thus $80-85 \%$ originates from sorting mistakes.

Other impurities, besides the polymeric impurities, are found in the PE and PP washed milled goods as well, as is clear from the paragraph above. For these materials the composition of the sorted products is used to approximate the origins of these impurities (as described in paragraph 2.3.3).

Paper found in the PE sorted product paper originates mainly (85-97\%) from the PE packages themselves (such as labels), the rest of the paper originates from sorting mistakes. Paper found in the PP sorted product could originate from the PP packages as well as from sorting mistakes. The amount of paper originating from the PP packages varies between 30 to $70 \%$.

All glass objects in the sorted product, from as well the PE and the PP sorted product originate from sorting mistakes. PE and PP packages normally do not contain glass parts.

Metal objects in the PE and PP sorted product originate from both the packages themselves, such as metal caps and aluminium lids, as from sorting mistakes. Metal in the PE sorted product originates for 25 to $60 \%$ from the packages themselves, for the PP sorted product this range is 40 to $65 \%$. 


\subsection{Pellets}

The analysis results of both the rPP and rPE pellets are described in this section. A description of the methods is found in section 2.3.2.

\subsubsection{Analysis of rPP pellets}

\subsubsection{Polymer melt flow results}

Table 5.3 shows that the measured results for melt flow index are comparable to the data specified by the companies in the technical datasheets. However, it is clear that the differences in MFI of the products in the market are large, from low-medium flows with MFI around 10-20 to high flow materials with MFI of $40-50 \mathrm{~g} / 10 \mathrm{~min}$ at the specified conditions. These differences in the viscous behaviour of the rPP samples are also observed in the complex viscosity results, lower viscosity values at $1 \mathrm{rad} / \mathrm{second}$ are obtained for high flow rPP (around $500 \mathrm{~Pa} . \mathrm{s}$ ) and much higher values are obtained for low and medium flow samples (above 1200 Pa.s). However, at high shear rates of 1000 $\mathrm{rad} / \mathrm{second}$ (fast flow), the differences in viscosity values become smaller, varying from 60-100 Pa.s. During injection moulding, fast flow is expected, therefore, it is expected that at fixed temperature and pressure all materials can be injection moulded. However, based on the different viscosity at low rates and the different MFI, it is clear that these commercial rPP products are suitable for different injection moulding applications.

Table 5.3 Measured melt flow index and viscosity at low (1 rad/second) and high (1000 $\mathrm{rad} / \mathrm{second}$ ) flow rates of the received market rPP samples.

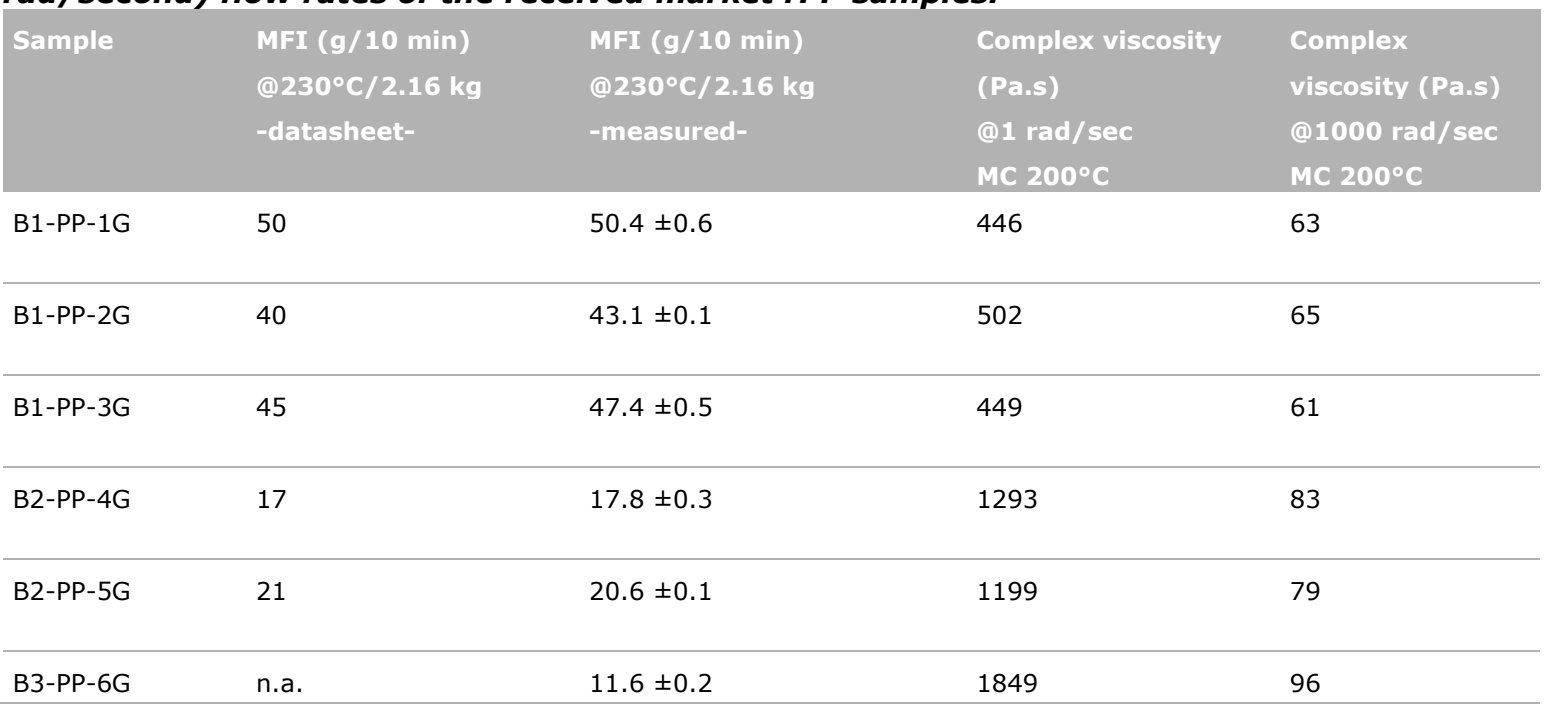

n.a. = not available

\subsubsection{Chemical and thermal analysis}

DSC analysis shows three distinguishable peaks (Figure 5.3) in all rPP received samples: one endothermic peak at around $130^{\circ} \mathrm{C}$, corresponding to the melting temperature of PE. A larger endothermic peak at around $170^{\circ} \mathrm{C}$ corresponding to the melting temperature of PP. And a third exothermic peak above $210^{\circ} \mathrm{C}$. Maximum temperatures and enthalpy energies are listed in Table 5.4. The first two peaks overlap, therefore the calculated values of PP crystallinity (" $X$ " \%PP) and PE content (\%PE) are only estimations and not absolute values.

The third peak observed in all rPP heating curves is relatively small, this peak appears at different temperatures above $210^{\circ} \mathrm{C}$. Most probably, it is the degradation or consumption of specific additives used in PP products, for example heat stabilizers, antioxidants or processing aids. For three of the rPP samples a complementary TGA measurement was done (see Appendix G). For samples 1G and 6G weight loss is observed around these temperatures, however, for sample 4G this effect is different, with a very sharp mass decrease, indicating other mechanism. 


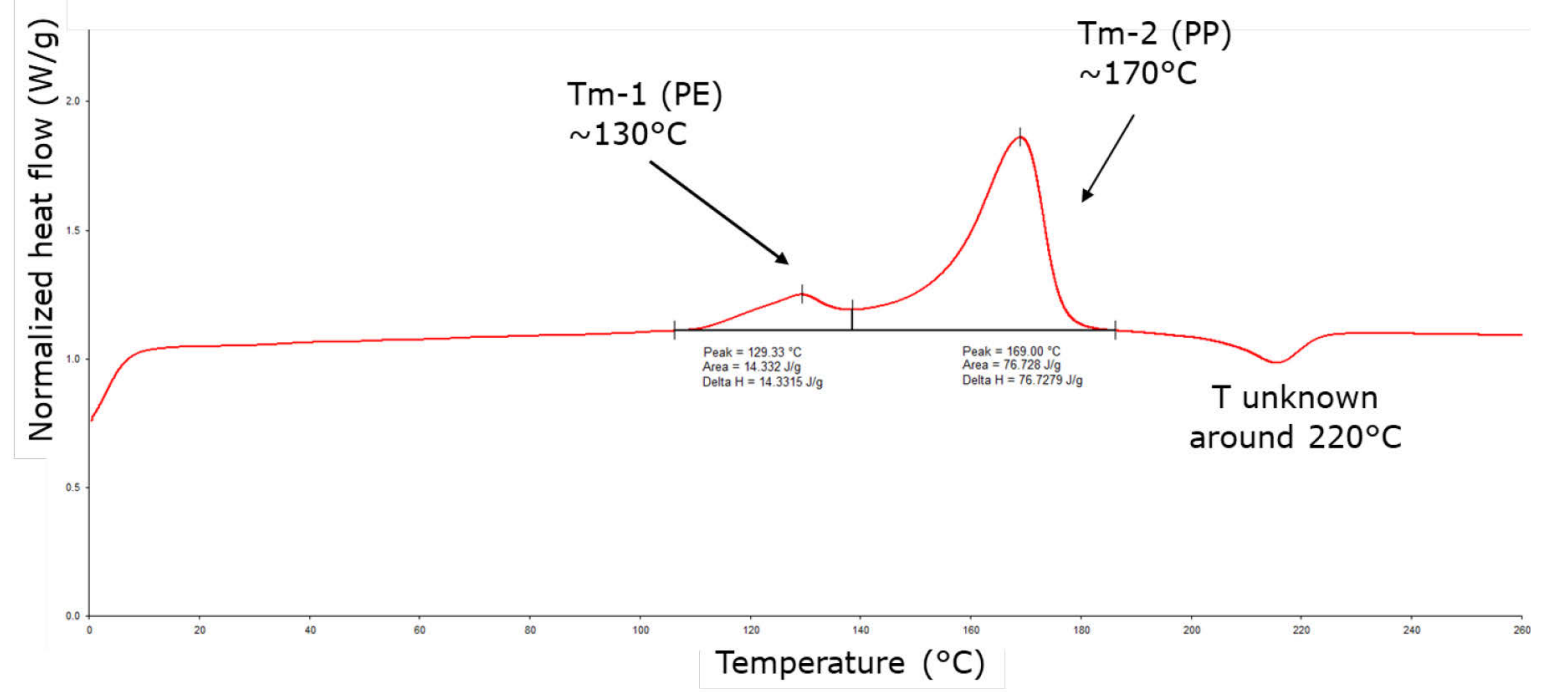

Figure 5.3 Typical rPP DSC first heating curve, in this case shown for sample B1-PP-3G

DSC analysis of the pellets confirms the observations done in washed milled goods: all the rPP pellet samples contain PE as impurity, roughly 5 to $9 \%$. This is likely to be a slight overestimation as compared to the washed milled goods analysis where maximum amounts of $4 \%$ are found (see section 5.1.1) due to the partial peak overlap in the heating curve. Furthermore, the degrees of crystallinity found in the rPP pellets vary between 33 and $38 \%$, a relatively small variation, indicating that the crystallinity of all rPP commercial samples is comparable.

Table 5.4 Melting temperatures (Tm) and enthalpies ( $\triangle \mathrm{H}$ ) of the different peaks found in rPP samples. Calculated mass percentage of PE present in the sample (\%PE) and total crystallinity of the PP fraction (" $X " \%) . T * u n k n o w n$ is the maximum temperature of an exothermic peak found in all samples.

\begin{tabular}{|c|c|c|c|c|c|c|c|}
\hline Code & $\begin{array}{l}\operatorname{Tm}[\mathrm{PE}] \\
\left({ }^{\circ} \mathrm{C}\right)\end{array}$ & $\begin{array}{l}\triangle H[P E] \\
(J / g)\end{array}$ & $\%$ PE & $\begin{array}{l}\operatorname{Tm}[\mathrm{PP}] \\
\left({ }^{\circ} \mathrm{C}\right)\end{array}$ & $\begin{array}{l}\Delta H[P P] \\
(\mathrm{J} / \mathrm{g})\end{array}$ & $\begin{array}{c}\text { X" \% } \\
\text { PP }\end{array}$ & $\begin{array}{l}\mathrm{T}^{*} \text { unknown } \\
\left({ }^{\circ} \mathrm{C}\right)\end{array}$ \\
\hline B1-PP-1G & 128 & 13 & 7 & 168 & 68 & 33 & 215 \\
\hline B1-PP-2G & 131 & 17 & 9 & 169 & 74 & 36 & 215 \\
\hline B1-PP-3G & 129 & 14 & 8 & 169 & 77 & 37 & 220 \\
\hline B2-PP-4G & 135 & 11 & 6 & 166 & 74 & 36 & 240 \\
\hline B2-PP-5G & 128 & 8 & 5 & 169 & 79 & 38 & 250 \\
\hline B3-PP-6G & 129 & 16 & 8 & 168 & 72 & 35 & 210 \\
\hline
\end{tabular}

Infrared spectroscopy confirms the presence of PE in the rPP samples. Spectra showing the distinguishing peaks of PP and other important qualitative characteristics of the samples are shown in Figure 5.4. A summary of the typical wavenumbers of the peaks is given in Table 5.5. Though the absorptions of PE and PP overlap for a large part, the absorption peaks around $750-720 \mathrm{~cm}^{-1}$ are unique for PE and can be clearly distinguished in the spectra. Other visible characteristics are the peak around $1730 \mathrm{~cm}^{-1}$, which corresponds to the carbonyl stretch vibration of PET. And the hump observed between 750 and $500 \mathrm{~cm}^{-1}$ which is usually indication of the presence of inorganic fillers, which will correspond to the white pigment used in one of the samples. 


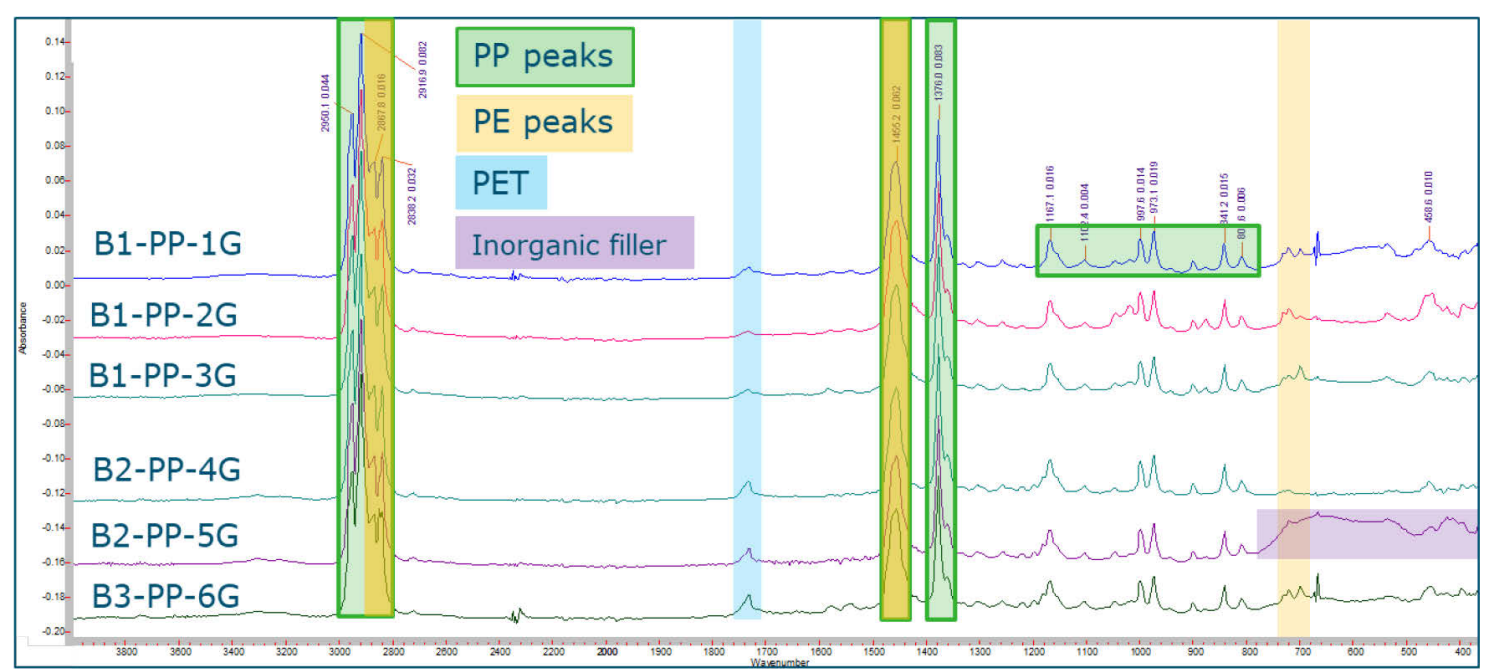

Figure 5.4 FTIR spectra of relative absorbance vs wavenumber(from 3800 to 400) in $\mathrm{cm}^{-1}$ of the six rPP samples received from the market

Table $5.5 \quad$ Typical wavenumbers of characteristic peaks present in the PP and PE spectra.

\begin{tabular}{lll} 
Wavenumber $\left(\mathrm{cm}^{-1}\right)$ & Origin & Polymer \\
\hline $2970-2950$ & Methyl C-H asymmetric stretch & PP \\
\hline $2935-2915$ & Methylene asymmetric stretch & PP and PE \\
\hline $2880-2860$ & Methyl C-H symmetric stretch & PP \\
\hline $2865-2845$ & Methylene symmetric stretch & PP and PE \\
\hline $1740-1700$ & Carbonyl stretch & PET \\
\hline $1485-1445$ & Methylene C-H bend & PP and PE \\
\hline $1470-1430$ & Methyl C-H asymmetric bend & PP \\
\hline $1380-1370$ & Methyl C-H symmetric bend & PP \\
\hline $1300-700$ & Skeletal C-C vibration & PP \\
\hline $750-720$ & Methylene rocking & PE \\
\hline $750-400$ & Inorganic particles & fillers \\
\hline
\end{tabular}

\subsubsection{CIELAB colour characterization}

Colour is one of the obstacles in use of recycled plastic, which is mentioned by the packaging industry. The colour parameters $L^{*}, a^{*}$ and $b^{*}$ of the rPP pellets and the description of the colour according to the datasheet are given in Table 5.6. As expected, samples $4 \mathrm{G}$ and $5 \mathrm{G}$ which are in the market as natural or white colour show larger $L^{*}$ than the rest of the samples. A difference is observed between the two black samples, indicating that even though they are both black, the colour is measurably different and their use will render products with different colour.

Table 5.6 Measured colour of the different rPP received.

\begin{tabular}{|c|c|c|c|c|}
\hline Sample code & Colour & L* & a* & b* \\
\hline B1-PP-1G & Terracotta & $34.3 \pm 0.4$ & $19.4 \pm 0.5$ & $21.3 \pm 0.5$ \\
\hline B1-PP-2G & Black & $16 \pm 1$ & $-0.2 \pm 0.1$ & $-0.6 \pm 0.1$ \\
\hline B1-PP-3G & Grey & $42 \pm 1$ & $-0.7 \pm 0.1$ & $1.1 \pm 0.2$ \\
\hline B2-PP-4G & Natural & $68 \pm 1$ & $-4.4 \pm 0.1$ & $9.1 \pm 0.4$ \\
\hline B2-PP-5G & White & $80 \pm 1$ & $-3.2 \pm 0.2$ & $3.9 \pm 0.2$ \\
\hline B3-PP-6G & Black & $33 \pm 2$ & $0.1 \pm 0.1$ & $1.0 \pm 0.1$ \\
\hline
\end{tabular}




\subsubsection{Analysis of rPE pellets}

\subsubsection{Polymer melt flow results}

The results for the measured melt flow indices are identical to the data specified in the technical datasheet, as can be seen in Table 5.7. Complex viscosity values are extremely high at the measured temperatures but the differences between the samples are very small. These materials are certainly suitable for processing of extrusion applications and also for some blow moulding applications.

Table 5.7 Measured melt flow index and viscosity at low (1rad/second) and high (1000 rad/sec) shear rates of the received market rPE samples.

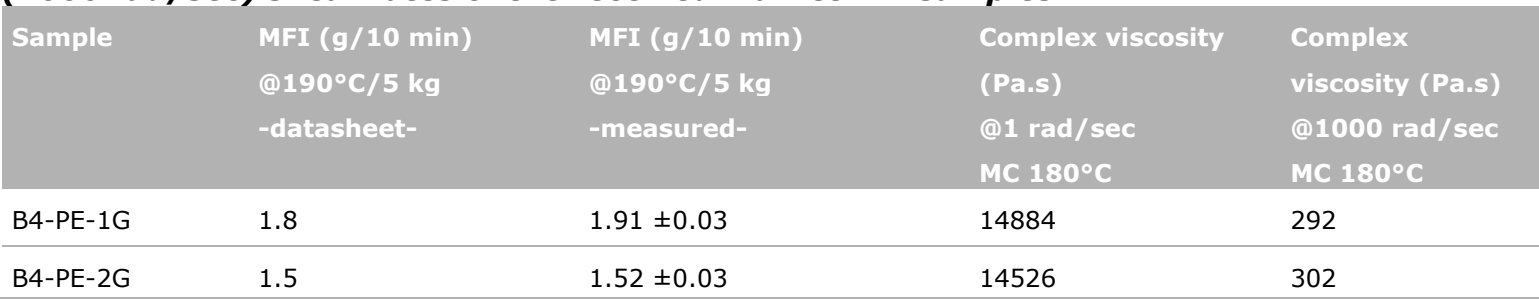

\subsubsection{Chemical and thermal analysis}

Thermal analysis by means of DSC shows two peaks in both rPE received samples: a strong endothermic peak around $136^{\circ} \mathrm{C}$, corresponding to the melting temperature of PE and a small endothermic peak around $164^{\circ} \mathrm{C}$ corresponding to the melting temperature of PP. The typical heating curve is shown in Figure 5.5. Peak temperatures and enthalpy energies are shown in Table 5.8. From the first peak the PE content (\%PE) can be estimated, it can be seen that PE content varies from $93 \%$ for one sample to $87 \%$ for the other one, these numbers are in agreement with the purity levels found in the washed milled goods of around $90-97 \%$.

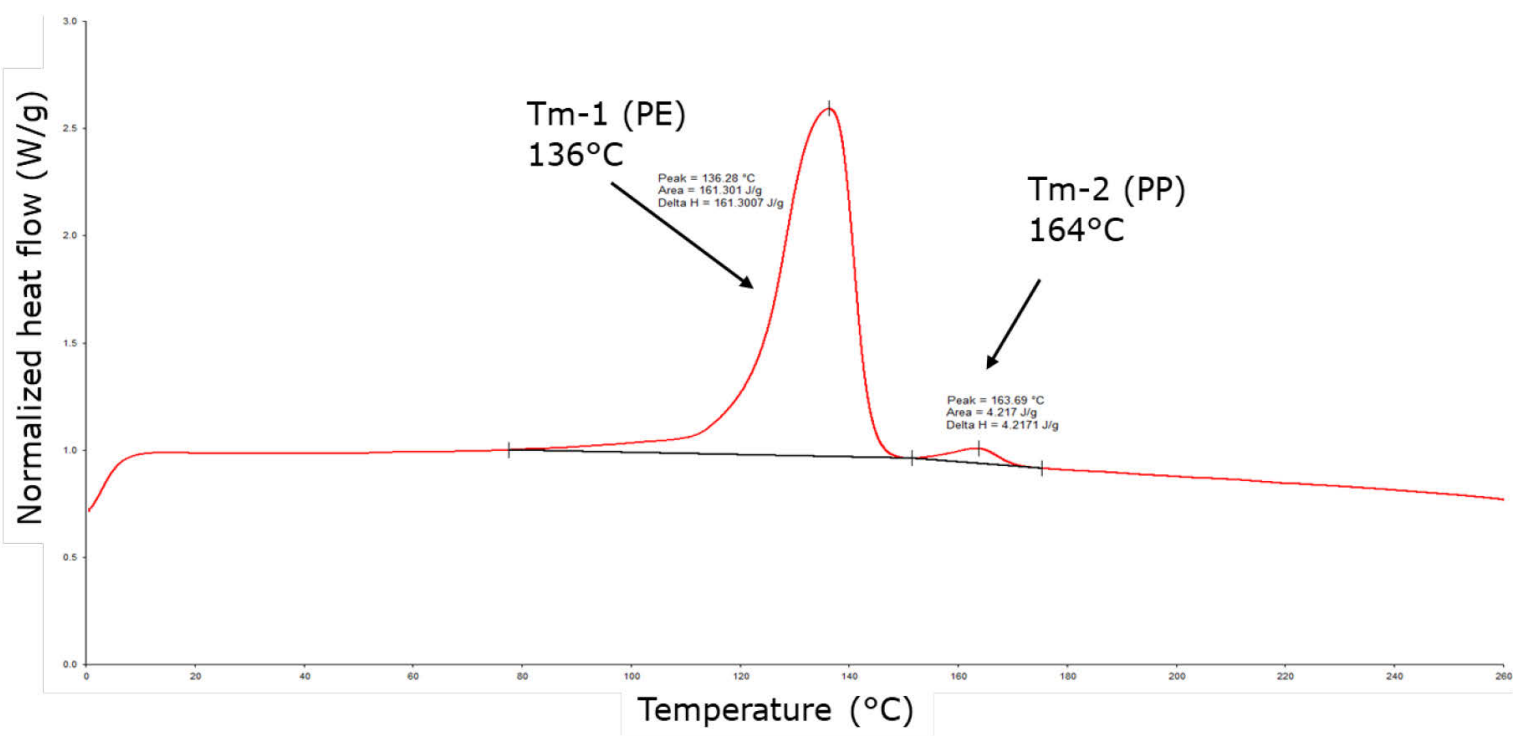

Figure 5.5 Typical rPE first heating curve (B4-PE-1G) as measured by DSC

Table 5.8 Melting temperatures (Tm) and enthalpies ( $\triangle \mathrm{H}$ ) of the different peaks found in rPE samples. Calculated mass percentage of PE present in the sample (\%PE).

\begin{tabular}{llllll} 
Code & $\begin{array}{l}\operatorname{Tm}[\mathrm{PE}] \\
\left({ }^{\circ} \mathbf{C}\right)\end{array}$ & $\begin{array}{l}\Delta \mathbf{H}[\mathrm{PE}] \\
(\mathbf{J} / \mathbf{g})\end{array}$ & $\%$ PE & $\begin{array}{l}\operatorname{Tm}[\mathbf{P P}] \\
\left({ }^{\circ} \mathbf{C}\right)\end{array}$ & $\begin{array}{l}\Delta \mathbf{H}[\mathbf{P P}] \\
(\mathbf{J} / \mathbf{g})\end{array}$ \\
\hline B4-PE-1G & 136 & 161 & 93 & 164 & 4 \\
\hline B4-PE-2G & 136 & 174 & 87 & 163 & 1
\end{tabular}

Infrared spectroscopy confirms the presence of PP in the two rPE samples. Spectra showing the distinguishing peaks of PE and very small signature peaks of PP are shown in Figure 5.6. Typical wavelengths and origin are shown in Table 5.5. 


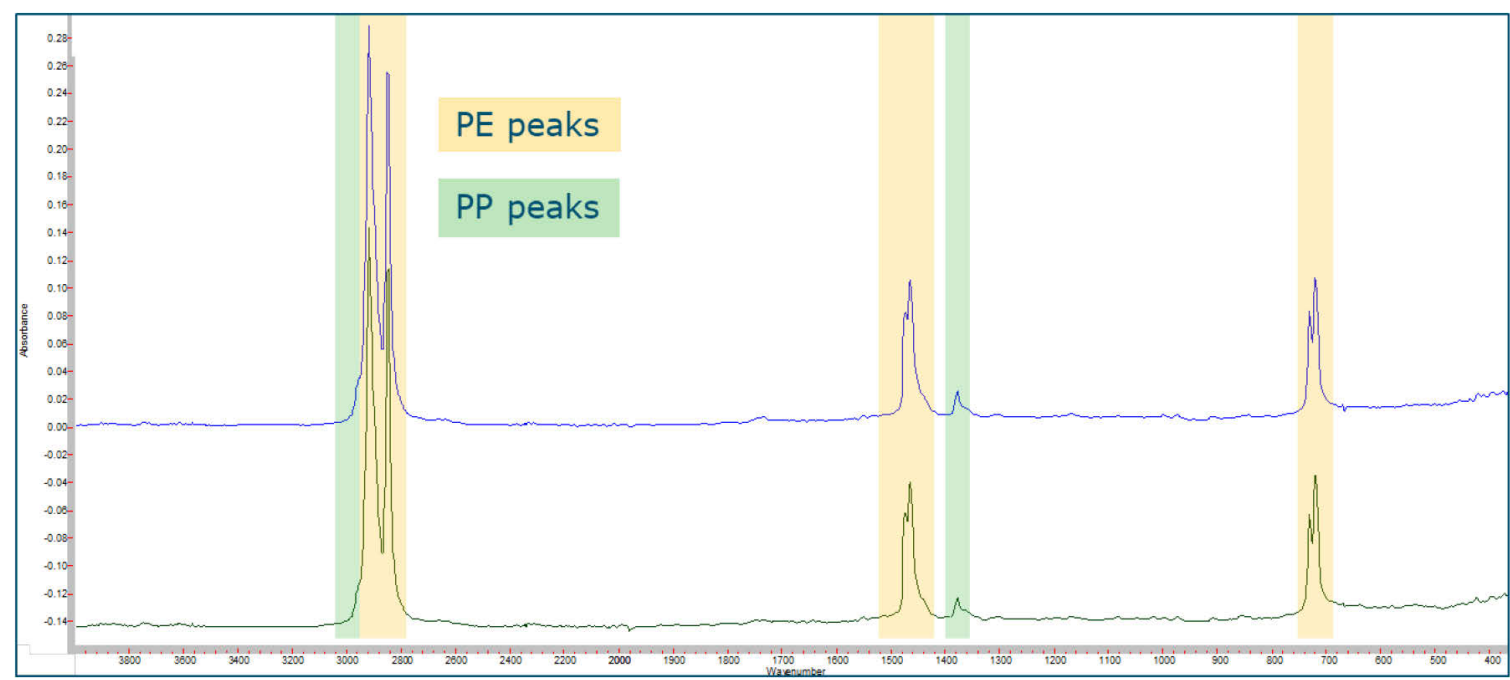

Figure 5.6 FTIR spectra of relative absorbance vs wavenumber (from 3800 to 400) in $\mathrm{cm}-1$ of the two rPE samples received from the market

\subsubsection{CIELAB colour characterization}

The colour parameters $L^{*}, a^{*}$ and $b^{*}$ of the two rPE samples as well as the description of the colour given in the datasheet are given in Table 5.9. Ivory sample shows larger $L^{*}$ than the grey one.

Table 5.9 Measured colour of the different rPE received.

\begin{tabular}{lllll} 
Sample code & Colour & L* & a* & b* \\
B4-PE-1G & Grey & $37 \pm 2$ & $-3.9 \pm 0.4$ & $-3.3 \pm 0.2$ \\
\hline B4-PE-2G & Ivory & $73 \pm 2$ & $-3.4 \pm 0.1$ & $2.1 \pm 0.4$ \\
\hline
\end{tabular}




\section{Impact of impurities in PP and PE recycled plastics}

\subsection{Sample preparation: from sorted product to washed milled goods}

\subsubsection{Composition of the sorted products and its representativeness}

The average composition of the targeted packages in the PP and PE sorted product is listed in Table 6.1 and Table 6.2. These compositions are compared to the modelled composition of the targeted packages in average Dutch PP and PE sorted products from separate collection and recovery from Municipal Solid Waste (MSW), in 2017 [Brouwer, et al. 2019].

Table 6.1 Average composition of the targeted packages in the PP sorted product, input composition in mechanical recycling process and modelled average composition of the targeted packages in the PP sorted product.

\begin{tabular}{l|c|c|c} 
& $\begin{array}{c}\text { Composition PP sorted } \\
\text { product }(\mathrm{n}=4)\end{array}$ & $\begin{array}{c}\text { Modelled average } \\
\text { composition of Dutch PP } \\
\text { sorted product from } \\
\text { separate collection* }\end{array}$ & $\begin{array}{c}\text { Modelled average } \\
\text { composition of Dutch PP } \\
\text { sorted product from } \\
\text { recovery from MSW* }\end{array}$ \\
\hline PP bottles & $0.03 \pm 0.06 \%$ & $0.4 \pm 0.5 \%$ & $1.1 \pm 0.9 \%$ \\
\hline PP flasks & $10.2 \pm 1.0 \%$ & $15 \pm 5 \%$ & $11 \pm 2 \%$ \\
\hline PP other rigid packages & $89.8 \pm 1.0 \%$ & $84 \pm 32 \%$ & $88 \pm 22 \%$ \\
\hline
\end{tabular}

* Source: Brouwer, et al. 2019

Table 6.2 Average composition of the targeted packages in the PE sorted product, input composition in mechanical recycling process and modelled average composition of the targeted packages in the PE sorted product.

\begin{tabular}{l|c|c|c} 
& $\begin{array}{r}\text { Composition PE sorted } \\
\text { product }(n=5)\end{array}$ & $\begin{array}{r}\text { Modelled average } \\
\text { composition of Dutch PE } \\
\text { sorted product from } \\
\text { separate collection* }\end{array}$ & $\begin{array}{r}\text { Modelled average } \\
\text { composition of Dutch PE } \\
\text { sorted product from } \\
\text { recovery from Msw* }\end{array}$ \\
\hline PE bottles & $15 \pm 2 \%$ & $27 \pm 11 \%$ & $12 \pm 6 \%$ \\
\hline PE flasks & $74 \pm 3 \%$ & $66 \pm 20 \%$ & $71 \pm 21 \%$ \\
\hline PE other rigid packages & $11 \pm 3 \%$ & $7 \pm 5 \%$ & $17 \pm 13 \%$
\end{tabular}

* Source: Brouwer, et al. 2019

The comparisons show that the received samples of the PP and PE sorted product have a composition that is comparable to the average composition of these Dutch sorted products. Therefore the composition of the packages types in the sample is representative for a Dutch PP sorted product. The packaging types will mainly influence the grades of PP used in the packages, hence it is supposed that the mechanical properties of the materials produced will be representative as well. However, the colours of the packages might vary between samples, as this property is related to the brands of the packages and not related to the packaging type. Therefore a new sample with the same composition in packaging types might still have a different colour; a different shade of grey. 


\subsubsection{Mechanical recycling of sorted products}

Ten batches of roughly $5 \mathrm{~kg}$ of PP flakes which was composed of $6 \%$ flakes of PP non-beverage bottles and $94 \%$ flakes of PP miscellaneous rigid packages. This flake mixture had an average moisture level of $2 \pm 4 \%$. The ten batches were mechanical recycled according to the protocol in paragraph 2.4.1.2 and the results were averaged. Photos of the PP flakes before and after recycling are shown in Figure 6.1. The results are summarised in Table 6.3.

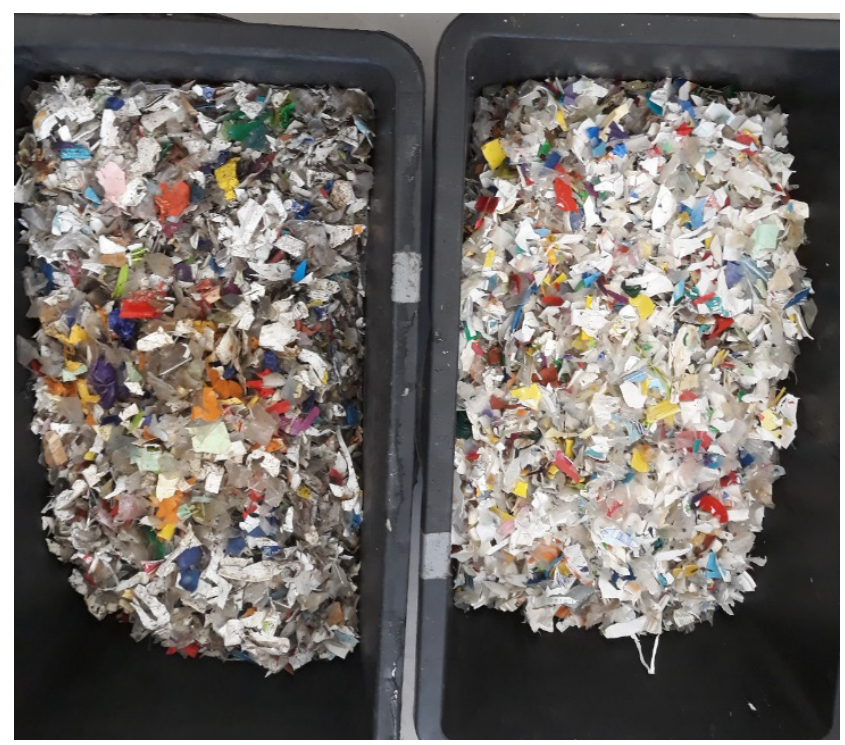

Figure 6.1 Flakes of rPP. Left: before washing, right: after washing

Table 6.3 Averaged mechanical recycling results for PP flakes.

\begin{tabular}{ll} 
Recycling products and wastes & Net recovered mass, [\%] \\
Main product, floating fraction & $90 \pm 2 \%$ \\
\hline By-product, sinking fraction & $1.4 \pm 0.6 \%$ \\
\hline Total sludge wastes & $3.0 \pm 1.2 \%$ \\
\hline Dissolved matter & $5.7 \pm 1.2 \%$
\end{tabular}

Ten batches of roughly $5 \mathrm{~kg}$ of PE flakes which was composed of $10 \%$ flakes of PE beverage bottles, $10 \%$ flakes of PE non-beverage bottles and $80 \%$ flakes of PE miscellaneous rigid packages. This flake mixture had an average moisture level of $5 \pm 3 \%$. The ten batches were mechanically recycled according to the protocol in section 2.4.1.2 and the results were averaged. Photos of the PE flakes before and after recycling are shown in Figure 6.2. The results are summarised in Table 6.4.

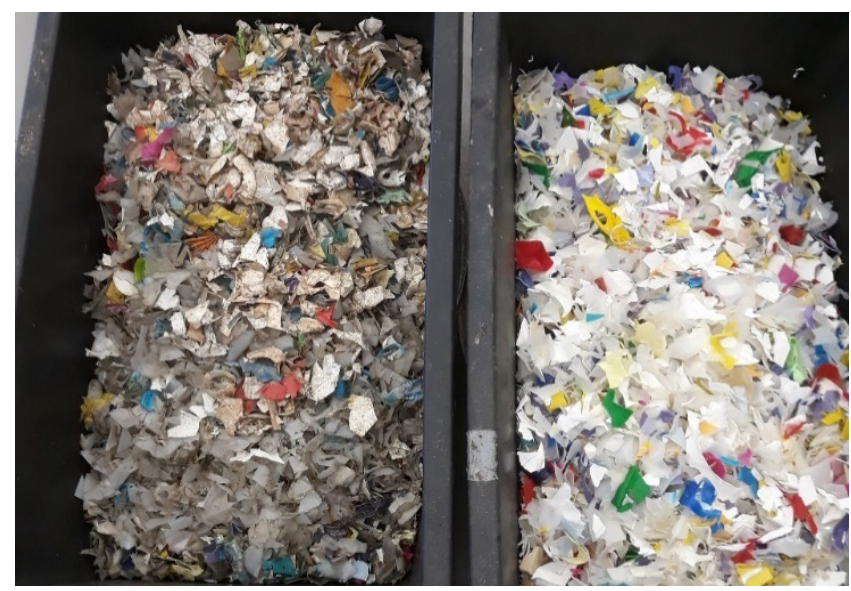

Figure 6.2 Flakes of rPE. Left: before washing, right: after washing 
Table 6.4 Averaged mechanical recycling results for PE flakes.

\begin{tabular}{ll} 
Recycling products and wastes & Net recovered mass, [\%] \\
Main product, floating fraction & $95 \pm 2 \%$ \\
\hline By-product, sinking fraction & $0.3 \pm 0.2 \%$ \\
\hline Total sludge wastes & $0.4 \pm 0.1 \%$ \\
Dissolved matter & $4 \pm 2 \%$
\end{tabular}

The mechanical recycling yields for both the PP flakes and the PE flakes are slightly higher than those previously reported for sorted PP and PE, respectively. [Thoden van Velzen et al. $2016 \mathrm{~A}$ ] This is likely caused by the fact that the feedstocks used in this study only contained 3 or 2 types of targeted packages and no sorting mistakes.

The flakes have been quickly screened with the sIRoPad (see section 2.3.1) for polymeric purity. Both samples of rPP and rPE have purity levels exceeding $99.5 \%$. In rPE the most common impurity was PP and vice versa. Sporadically other materials were found in the washed milled goods, but insufficient amounts for a reliable estimation of their concentration. The purity is - compared to industrial reality (see section 5.1) - extremely high.

\subsection{Processing and analysis of rPP material}

\subsection{1 rPP processing}

The added impurities were found to influence the processing (extrusion and injection moulding) of the rPP material. Critical extruder settings were the initial pressure measured before the melt filter and the consumed specific mechanical energy (SME) as calculated from the extruder speed and the torque. The pressure before the filter was allowed to increase up to 60 bar before replacing the filter. The number of times that the melt filter had to be switched is therefore a critical extrusion process parameter, together with the particles found on the melt filters. Photos on the particles found on the filters are shown in Table C.1 in Appendix C. All other parameters are summarized in Table 6.5. In this table additionally two critical parameters for the injection moulding process are given as example: injection pressure range and dosing time, as measured when tensile testing bars were injection moulded. Data available on injection moulding pressure and required dosing time for making the impact bars show similar trends and are therefore not reported here. The sample names refer to the sample codes as explained in 2.4.2.1. 
Table 6.5 Observations during processing of rPP flakes with different impurities and virgin materials.

\begin{tabular}{|c|c|c|c|c|c|c|}
\hline Composition & $\begin{array}{l}\text { Initial } \\
\text { extruder } \\
\text { pressure } \\
\text { before the } \\
\text { filter (bar) }\end{array}$ & $\begin{array}{l}\text { Extruder } \\
\text { SME } \\
(\mathbf{k W h} / \mathbf{k g})\end{array}$ & $\begin{array}{l}\text { Times melt } \\
\text { filters had to } \\
\text { be switched } \\
\text { per half hour } \\
\text { ( } \sim 2.5 \mathrm{~kg} \\
\text { material) }\end{array}$ & $\begin{array}{l}\text { Particles found on } \\
\text { melt filter }\end{array}$ & $\begin{array}{l}\text { Injection } \\
\text { moulding } \\
\text { dosing time } \\
\text { (s) }\end{array}$ & $\begin{array}{l}\text { Injection } \\
\text { moulding } \\
\text { pressure range } \\
\text { (bar) }\end{array}$ \\
\hline Ref 1 & & & & & 4.7 & $550-580$ \\
\hline Ref 2 & & & & & 6.5 & $400-480$ \\
\hline 100rPP & 15 & 0.21 & 2 & $\begin{array}{l}\text { Aluminium, black, } \\
\text { yellow/green particles }\end{array}$ & 4.7 & $590-650$ \\
\hline 2rHDPE & 21 & 0.23 & 2 & $\begin{array}{l}\text { Aluminium, black } \\
\text { small particles, yellow } \\
\text { and big white } \\
\text { particles }\end{array}$ & 4.0 & $635-730$ \\
\hline 5 rHDPE & 17 & 0.21 & 2 & More white particles & 4.4 & $550-660$ \\
\hline 10rHDPE & 17 & 0.17 & 2 & $\begin{array}{l}\text { Still more white } \\
\text { particles }\end{array}$ & 4.1 & $615-665$ \\
\hline 2rLDPE & 17 & 0.20 & 2 & $\begin{array}{l}\text { Al, black and yellow } \\
\text { particles }\end{array}$ & 4.2 & $620-650$ \\
\hline 0.5PET & 21 & 0.20 & 6 & $\begin{array}{l}\text { A lot white particles } \\
\text { on the filter }\end{array}$ & 3.6 & $655-760$ \\
\hline 0.5PET - HT & 17 & 0.15 & 1 & Al and black particles & 4.3 & $600-650$ \\
\hline $0.5 P S$ & 20 & 0.19 & 2 & $\begin{array}{l}\text { White, green, black } \\
\text { and glass-like } \\
\text { particles }\end{array}$ & 4.0 & $650-670$ \\
\hline $0.5 r P V C$ & 17 & 0.18 & 2 & $\begin{array}{l}\text { Al, black and yellow } \\
\text { particles }\end{array}$ & 4.3 & $615-650$ \\
\hline 3.5rPPfilm & 18 & 0.19 & 2 & $\begin{array}{l}\text { Black, Al and colourful } \\
\text { pieces }\end{array}$ & 4.0 & $620-665$ \\
\hline 0.5 rAlfilm & 20 & 0.17 & 5 & $\begin{array}{l}\text { Al, dark green and } \\
\text { brown pieces }\end{array}$ & 4.4 & $570-640$ \\
\hline 50rIML & 11 & 0.14 & 2 & $\begin{array}{l}\text { Al, green, yellow and } \\
\text { black particles }\end{array}$ & 4.5 & $605-650$ \\
\hline 5IML & 10 & 0.19 & $1 *$ & $\begin{array}{l}\text { Al, green and white } \\
\text { particles }\end{array}$ & 4.9 & $406-419$ \\
\hline
\end{tabular}

* less material produced, error when switching filter during extrusion.

The reference materials 1 and 2 were received as extruded pellets from the supplier, so no extrusion was needed. For the extruded samples, in all cases, including the reference $100 \%$ rPP material, the filter had to be replaced at least twice during the processing period (roughly half an hour is needed to convert the $2.5 \mathrm{~kg}$ of flakes into extruded pellets). In the case of $0.5 \%$ PET, filters were so quickly clogged (every 2-3 minutes) that after 6 times of switching the filters it was decided to process the rest of the material at higher temperatures $(\mathrm{HT})$. Therefore, maximum temperature was increased to $260^{\circ} \mathrm{C}$ (above melting temperature of PET). The amount of sample processed at HT was less and it could be processed with only one filter. For samples containing $0.5 \%$ coated Aluminium films, 5 filter switches were needed. So the samples to which PET and metallised film were added are relatively difficult to process in an extruder with a filtration system like the one used here.

Small flat silvery grey particles were found in all the filters, these particles are most probably aluminium (Al) flakes from packaging parts, for example lids or small pieces of aluminium coated packaging. Small scale lab tests putting the particles in a solution of sodium hydroxide showed that 
some of the particles dissolved, that can be used as an indication of their origin. Element analysis was not performed in these samples.

Also, yellow/green un-melted fibre-like particles were found in all samples, they were identified with FTIR. Some of them were identified as PET materials and some of them as nylon (see Table C.2 in Appendix C). Some transparent, glass-like particles found in the filters (for example the ones of 0.5PS) were identified as silicon, they are most likely silicon valves and inlays. Black particles were difficult to identify since they fall apart when trying to get them out of the filter, probably indicating carbonized materials, spectra shows paper. White particles were mainly observed in the samples 2,5 and 10rHDPE, they are un-melted PE pieces.

When looking at the injection moulding parameters given in Table 6.5, already the reference materials show differences regarding dosing times and a wide range of pressure: from 400 to 480 bar for one material and between 550 and 580 bar for the other one. However, the pressures needed to inject materials containing rPP were larger than 550 bar and could reach up to 760 bars. Injection times were in most cases shorter than 4.7 seconds, with exception of the material containing $5 \%$ IML. This material was injected in a second series of trials at a slightly different condition which increased the dosing time and decreased the injection pressure below 420 bar. Injection moulded materials have already passed the extrusion step which partially filters out unmelted polymeric impurities and solid particles larger than $250 \mu \mathrm{m}$ (sieve size). Therefore, no clear trend is observed during injection moulding. All studied materials could be injection moulded in relatively short times, comparable to the references.

\subsubsection{Polymer melt flow results}

The MFI is a crucial technical parameter in technical datasheets to assess the applicability of a given polymer for example in injection moulded products. Virgin PP polymer products can be classified as "high flow" if their MFI is larger than $30 \mathrm{~g} / 10$ minutes, "medium flow" when their MFI is between 30 and $10 \mathrm{~g} / 10$ minutes and "low flow" when the MFI is lower than $10 \mathrm{~g} / 10$ minutes. These limits can vary per supplier or per application. MFI values of the prepared samples are shown in Figure 6.3. It can be seen that HDPE and LDPE even in amounts of $2 \%$ decrease the MFI of the rPP materials. This is also true for most of the other added impurities but the effect is smaller. Samples where $50 \%$ of the bodies are replaced by bodies with in-mould labels (50IML) show a reversed behaviour, MFI increases compared to $100 \%$ rPP. Similar flow performance is observed in the spiral flow measurements (see Table 6.6 and Figure 6.3). Here also impurities decrease the maximum achieved flow of $87 \mathrm{~cm}$ for $100 \%$ rPP to values below $80 \mathrm{~cm}$ for most of the added impurities. Except the samples with injection moulded labels, here spiral flow increases or stays at the level of the $100 \%$ rPP. In general, flow of all rPP samples is considerably different to the flow of virgin materials. For the rPP samples analysed here, MFI and spiral flow follow the same trend, both give flow information that can be directly translated to the application of rPP in injection moulded products.

MFI is usually a single point measurement of the viscosity behaviour of the polymer. Complementary measurements such as dynamic rheometry give a more detailed insight in the viscoelastic behaviour of the sample at different shear rates. Results of these measurements are shown in Appendix D, Figure D.1. 


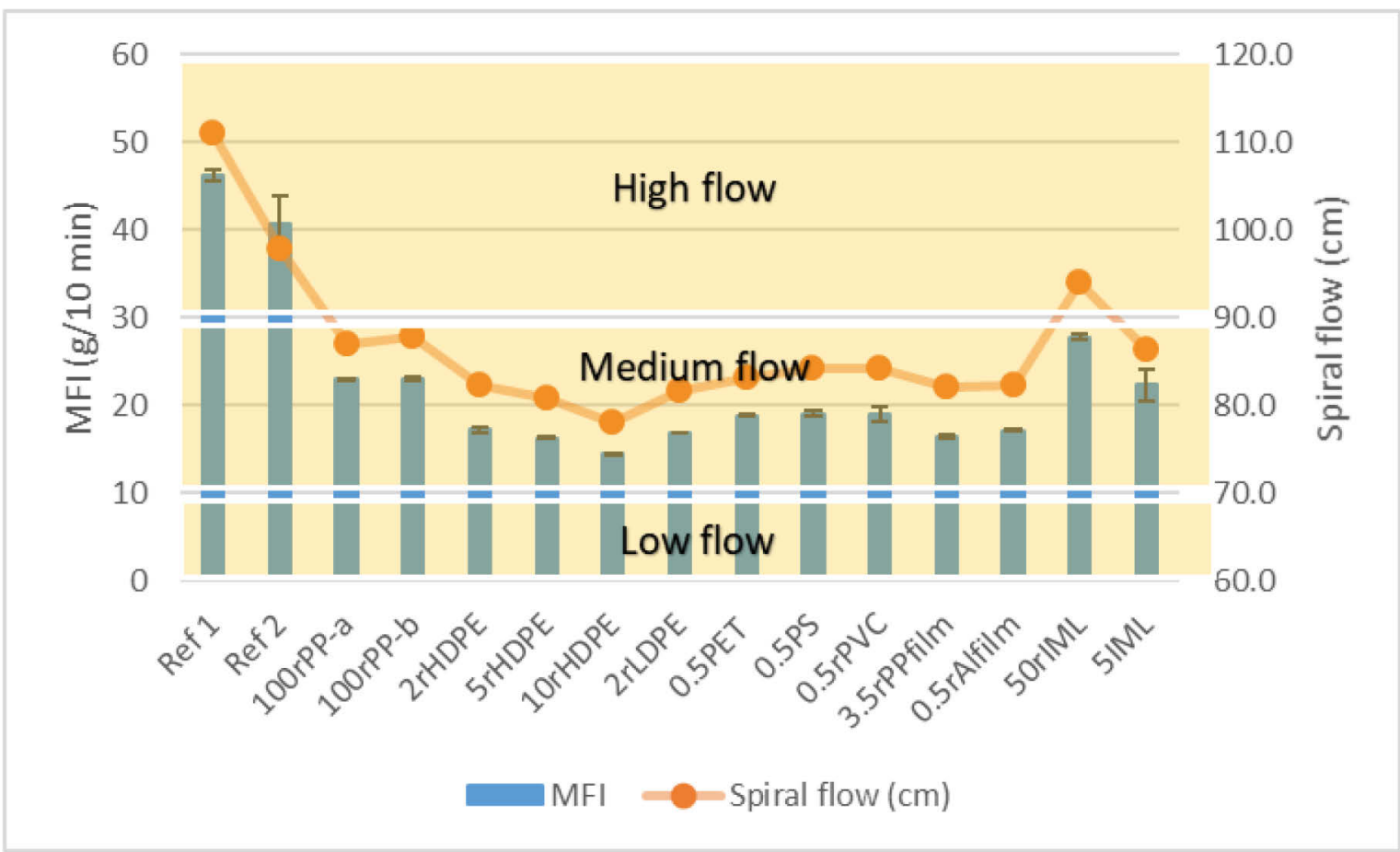

Figure 6.3 Flow properties MFI and spiral flow at $230^{\circ} \mathrm{C}$ of the studied rPP with different impurities compared to two high flow reference materials. Regions of high, medium and low flow are based on typical MFI values

Table 6.6 Measured melt flow index, spiral flow and their corresponding standard deviations (std).

\begin{tabular}{|c|c|c|c|c|c|}
\hline Sample & $\begin{array}{l}\text { Average MFI } \\
\text { (g/10 min) } \\
\text { @ } 230^{\circ} \mathrm{C} / 2.16 \mathrm{~kg}\end{array}$ & $\begin{array}{l}\text { Std } \\
\text { MFI }\end{array}$ & $\begin{array}{l}\text { Average } \\
\text { spiral flow } \\
(\mathrm{cm})\end{array}$ & & $\begin{array}{l}\text { Std } \\
\text { spiral } \\
\text { flow }\end{array}$ \\
\hline Ref 1 & 46.2 & \pm 0.6 & 110.9 & \pm & 0.2 \\
\hline Ref 2 & 41 & \pm 3 & 97.9 & \pm & 0.4 \\
\hline 100rPP & 22.9 & \pm 0.2 & 87.0 & \pm & 0.5 \\
\hline 2 rHDPE & 23.0 & \pm 0.3 & 87.8 & \pm & 0.3 \\
\hline 5rHDPE & 17.2 & \pm 0.3 & 82.4 & \pm & 0.2 \\
\hline 10rHDPE & 16.2 & \pm 0.1 & 80.8 & \pm & 0.3 \\
\hline 2rLDPE & 14.4 & \pm 0.1 & 78.0 & \pm & 0.5 \\
\hline $0.5 \mathrm{PET}$ & 16.9 & \pm 0.1 & 81.7 & \pm & 0.2 \\
\hline 0.5PET - HT & 18.8 & \pm 0.1 & 83.0 & \pm & 0.5 \\
\hline $0.5 \mathrm{PS}$ & 19.0 & \pm 0.3 & 84.2 & \pm & 0.2 \\
\hline $0.5 r P V C$ & 18.9 & \pm 0.9 & 84.1 & \pm & 0.2 \\
\hline 3.5rPPfilm & 16.4 & \pm 0.2 & 82.0 & \pm & 0.5 \\
\hline 0.5 rAlfilm & 17.1 & \pm 0.1 & 82.3 & \pm & 0.3 \\
\hline 50rIML & 27.7 & \pm 0.3 & 94.0 & \pm & 0.2 \\
\hline 5IML & 22 & \pm 2 & 86.4 & \pm & 0.3 \\
\hline
\end{tabular}

\subsubsection{Mechanical analysis}

Values of the Charpy notched impact strength vary substantial for polymers available on the market, they are usually specified in the datasheets of the produced polymer. PP types on the market are engineered to achieve certain impact properties while keeping its flow properties and reaching equilibrium with their stiffness. The measured impact strength of the prepared samples is shown in Figure 6.4. Impact strength of the $100 \%$ rPP is comparable to reference 2 of the two virgin materials. Adding different percentages of HDPE and LDPE increases slightly the notched impact strength of the samples. When measuring unnotched impact strength (Table D.1 in Appendix D), some of the test 
samples containing PE did not break at all; their impact strength was higher than for all other rPP samples.

Figure 6.4 also shows that sample 0.5PET-HT has the lowest impact strength of all measured samples. This sample was processed at a higher temperature than the rest $\left(260^{\circ} \mathrm{C}\right.$ instead of $\left.230^{\circ} \mathrm{C}\right)$ in order to avoid melt filter clogging. Increasing the temperature to improve the processing does not have a measurable effect in the MFI of the sample but has a negative impact in the mechanical properties. It is possible that when processing rPP at higher temperatures, stabilizers wear out and therefore more degradation of the molecular chains will occur in a second processing step. That will explain why no effect of the high temperature processing is observed on the MFI values but the effect is large in the impact properties of the injection moulded samples.

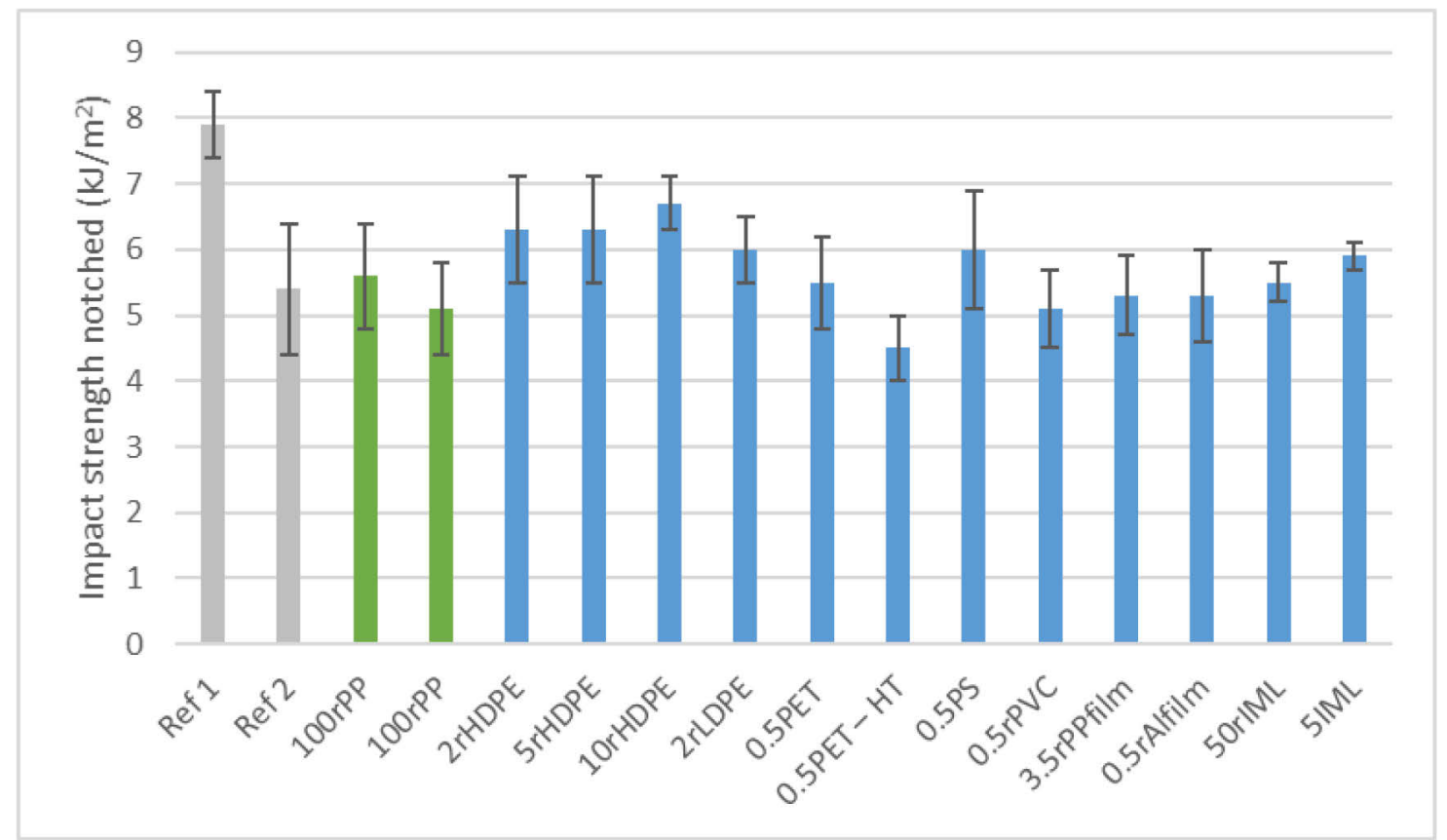

\section{Figure 6.4 Charpy impact strength of two reference PP samples (grey), 100\% rPP samples in duplo (green) and rPP samples with different impurities (blue)}

\subsubsection{Physical, chemical and thermal analysis}

The measured density of the two virgin materials was $885 \pm 10 \mathrm{~kg} / \mathrm{m}^{3}$ for Ref 1 and $895 \pm 10 \mathrm{~kg} / \mathrm{m}^{3}$ for Ref 2 . The density values for all samples containing rPP with and without impurities varied between 901 and $909 \mathrm{~kg} / \mathrm{m}^{3}$, resulting in an average density of $903 \pm 10 \mathrm{~kg} / \mathrm{m}^{3}$. Impurities in the rPP hardly impact the density of the injection moulded products.

Three typical DSC spectra of PP samples are shown in Figure 6.5. Here it can be seen that for virgin PP samples (Ref1) the larger endothermic melting peak around $170^{\circ} \mathrm{C}$ is very sharp. Conversely, for samples containing rPP this endothermic peak starts at lower temperatures and it has a kind of shoulder on the left hand side. This signal becomes stronger in samples containing PE but it clearly overlaps with the present shoulder of the PP, this could be attributed to a low molecular fraction of PP present in the recycled plastics, different types of PP homo/co polymers present in the rPP samples or alternatively to PE impurities (may be from rare multilayer materials, not commonly found in rigid PP). The exothermic peak observed above $210^{\circ} \mathrm{C}$ is only present in the first heating curve (similar to the one shown in Figure 5.3), it appears at higher temperatures for the reference materials and at lower temperatures for the rPP samples. Data for all samples is summarized in Table 6.7 in combination with temperatures at peak maxima, start melting temperatures and enthalpy energies. Since the PP and the PE peaks overlap, the calculated values of PP crystallinity (" $X$ " \%PP) and PE content (\%PE) are only estimations and not absolute values. 


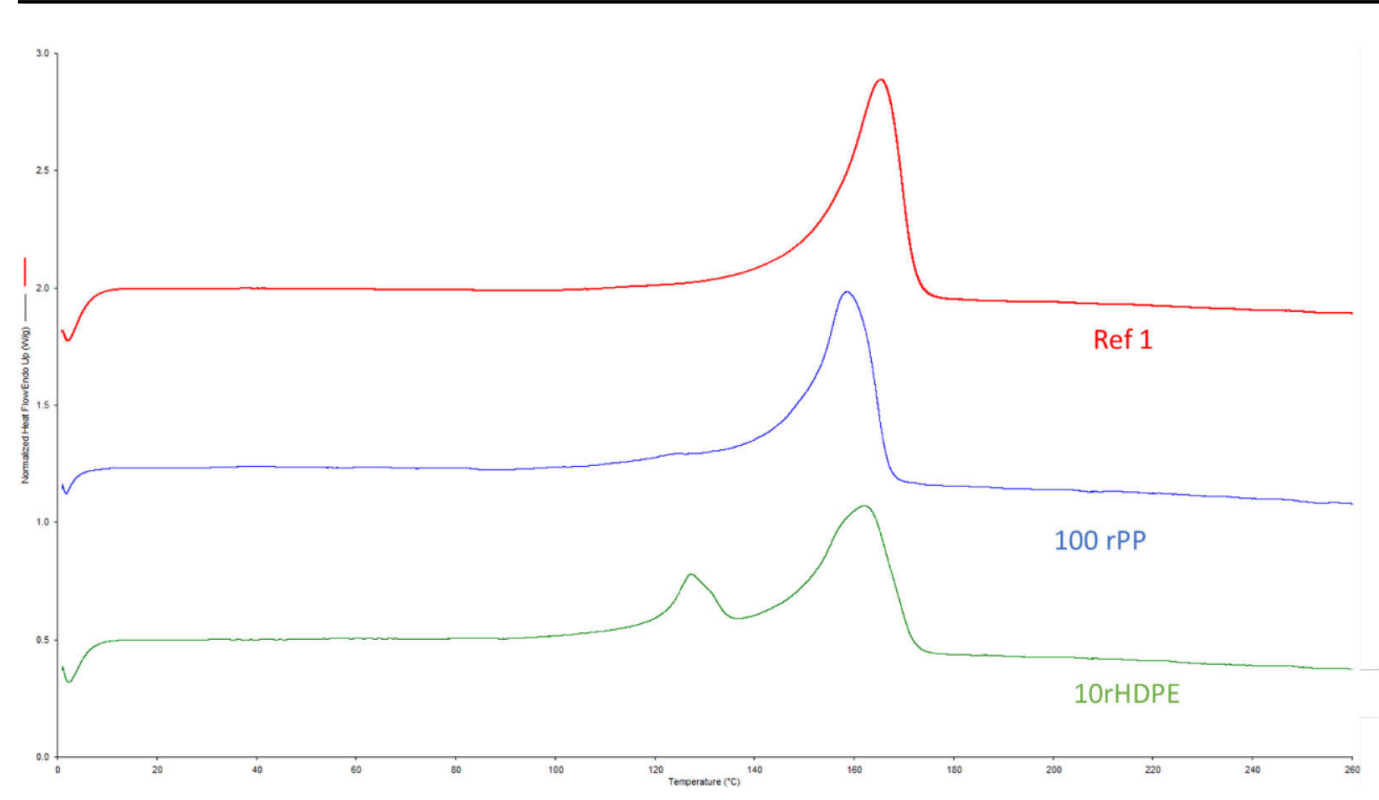

Figure 6.5 Typical second melting curves of 3 of the samples as measured by DSC, endothermic energy vs. temperature from 0 to $260^{\circ} \mathrm{C}$

Thermal analysis shows calculated amounts of 1, 3 and 5\% PE in rPP samples, probably an underestimation due to the overlap of the peaks and the calculation method (note: different calculation method than in chapter 5). Total crystallinity values of rPP vary between $42 \%$ and $44 \%$ for all samples except the sample with $5 \% \mathrm{IML}$, this sample was produced on another day, and behaved during processing different than the rest. It is unclear why.

Table 6.7 Melting temperatures (Tm) and enthalpies ( $\Delta H$ ) of the different peaks found in the second heating curve of rPP samples and the references. Calculated mass percentage of PE present in the sample (\%PE) and total crystallinity of the PP fraction (" $X$ "\%). $T^{*}$ unknown is the temperature of the exothermic peak found in all samples in the first heating curve.

\begin{tabular}{|c|c|c|c|c|c|c|c|}
\hline Code & $\begin{array}{l}\operatorname{Tm}[\mathrm{PE}] \\
\left({ }^{\circ} \mathrm{C}\right)\end{array}$ & $\begin{array}{l}\triangle H[P E] \\
(\mathrm{J} / \mathrm{g})\end{array}$ & $\%$ PE & $\begin{array}{l}\operatorname{Tm}[\mathrm{PP}] \\
\left({ }^{\circ} \mathrm{C}\right)\end{array}$ & $\begin{array}{l}\triangle H[P P] \\
(J / g)\end{array}$ & $\begin{array}{l}\text { "X"\% } \\
\text { PP }\end{array}$ & $\begin{array}{l}\mathrm{T}^{*} \text { unknown } \\
\left({ }^{\circ} \mathrm{C}\right)\end{array}$ \\
\hline Ref 1 & & & & 165 & 93 & $45 \%$ & 226 \\
\hline Ref 2 & & & & 149 & 80 & $38 \%$ & 225 \\
\hline 100rPPa & & & & 161 & 88 & $43 \%$ & 212 \\
\hline $100 \mathrm{rPPb}$ & & & & 159 & 87 & $42 \%$ & 209 \\
\hline 2rHDPE & 127 & 2 & $1 \%$ & 162 & 88 & $43 \%$ & 211 \\
\hline 5rHDPE & 127 & 7 & $3 \%$ & 161 & 86 & $42 \%$ & 213 \\
\hline 10rHDPE & 127 & 10 & $5 \%$ & 162 & 86 & $42 \%$ & 214 \\
\hline 2rLDPE & & & & 162 & 89 & $43 \%$ & 210 \\
\hline $0.5 \mathrm{PET}$ & & & & 160 & 88 & $42 \%$ & 209 \\
\hline 0.5PET - HT & & & & 160 & 89 & $43 \%$ & 210 \\
\hline $0.5 P S$ & & & & 160 & 90 & $43 \%$ & 211 \\
\hline $0.5 r P V C$ & & & & 161 & 87 & $42 \%$ & 209 \\
\hline 3.5rPPfilm & & & & 161 & 92 & $44 \%$ & 206 \\
\hline 0.5 rAlfilm & & & & 161 & 89 & $43 \%$ & 213 \\
\hline 50rIML & & & & 162 & 88 & $43 \%$ & 213 \\
\hline 5IML & & & & 160 & 78 & $37 \%$ & 205 \\
\hline
\end{tabular}


FTIR spectra show very small peaks in the region $720-750 \mathrm{~cm}^{-1}$ for samples containing $2 \%$ HDPE and $2 \%$ LDPE. These peaks become more evident when $5 \%$ HDPE is added and clearly distinguishable when $10 \%$ HDPE is added to the rPP. This confirms the presence of PE in the extruded pellets. Bumps in the region between 1500 and 1800 and between 3000 and $3500 \mathrm{~cm}^{-1}$ appear for $0.5 \mathrm{PET}, 0.5 \mathrm{PS}$ and 0.5 rPVC. These bumps become higher for samples containing 3.5\% PP film and 0.5Alfilm. Absorption peaks around $1750 \mathrm{~cm}^{-1}$ are caused by stretching vibrations of the ester carbonyl groups $(C=O)$ while absorption around $3400 \mathrm{~cm}^{-1}$ is caused by stretching of the alcohols $(-\mathrm{OH})$ or amine groups. Addition of $5 \% \mathrm{IML}$ also shows an increase in these regions.

DMTA results are shown in Figure 6.6. there is almost no difference observed between the rPP samples with or without impurities. The largest differences are observed between the samples made of virgin materials and the samples containing rPP. Reference 2 starts softening at lower temperatures than rPP samples and reference 1 keeps its strength to a higher temperature than rPP samples. rPP samples form a compact group following the same softening behaviour with increasing temperature.

Standardisation overview DMTA rPP samples

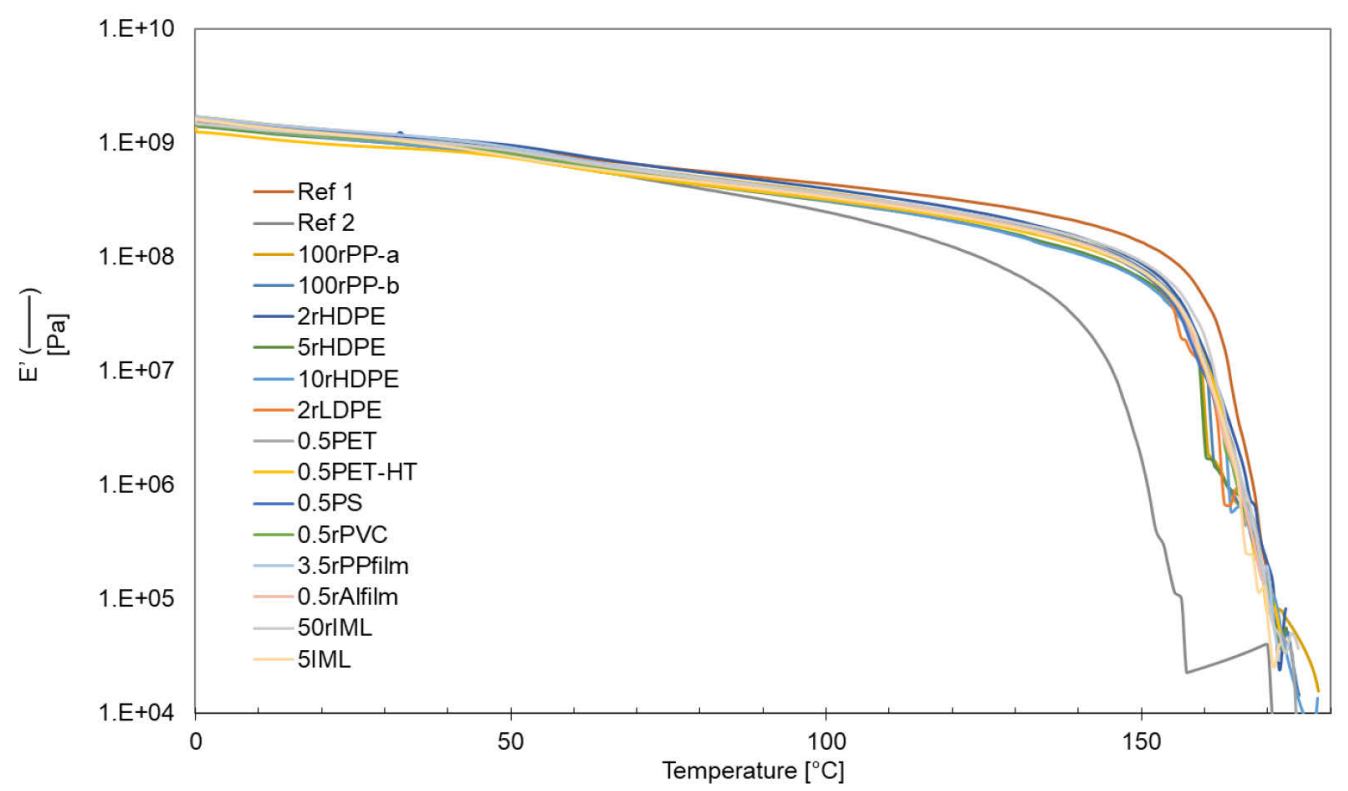

Figure 6.6 Overview of DMTA curves for all measured rPP samples

\subsubsection{Colour characterization}

Recycled samples are usually darker than virgin materials. Colour is influenced by the colour/ink of the collected packaging, therefore it is usually darker and with more colour tones than virgin materials which are white or transparent. When adding impurities, large effects can be observed in the difference in colour $\Delta \mathrm{E}$ with respect to the reference $100 \% \mathrm{rPP}$, see Figure 6.7 . These differences cannot directly be attributed to the colour of added impurities, except in the case of in mould labels, where either one type of label was added or $50 \%$ of the flakes were replaced by other packaging material. Polymers like PET are badly miscible with PP, therefore even a small amount largely influences the colour. Also the processing temperature changes the colour; this is visible in the 0.5PET-HT sample. As background information, table D.2 in Appendix D shows the detailed measured colour of the different virgin materials and the produced rPP samples. 


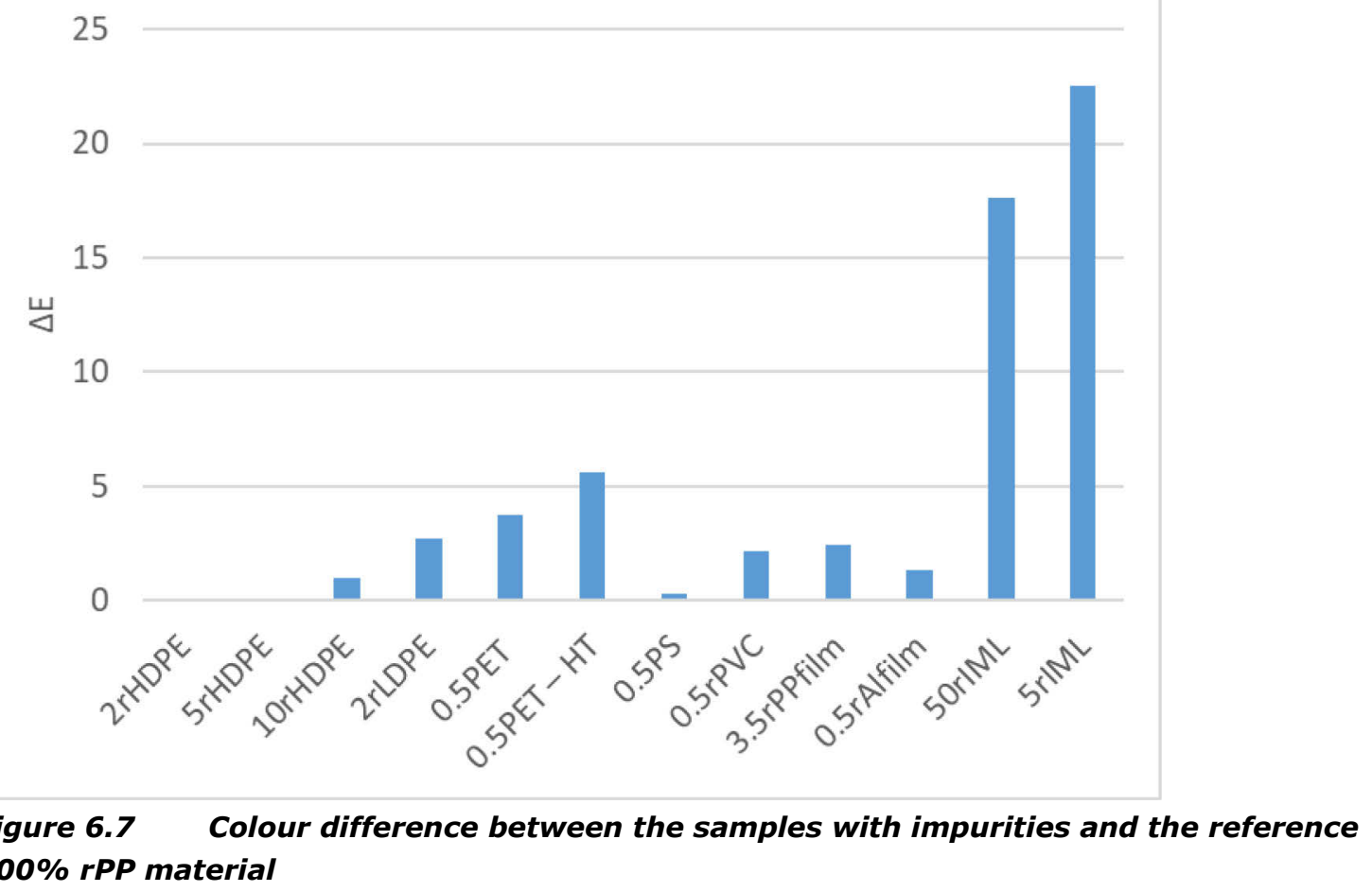

100\% rPP material

\subsection{Processing and analysis of rPE material}

\subsection{1 rPE processing}

During the extrusion and injection moulding processing of rPE materials with different impurities, some differences were observed, especially in the extruder energy consumption and in the injection times. Differences are tabulated in Table 6.8. Critical extruder settings were the initial pressure before the melt filter and the consumed specific mechanical energy (SME) as calculated from the extruder speed and the torque. The pressure before the filter was allowed to increase up to 105 bar before switching the filter, however, in most cases the melt filter had to be replaced only 2 or 3 times. Photos on the particles found on the filters are shown in Table C. 3 in Appendix C. The number of times that the melt filter had to be switched and a description of the particles found on the melt filters are shown in Table 6.8 .

In this table additionally two critical parameters for the injection moulding process are listed: minimum and maximum injection dosing time, average dosing time and pressure range. Sample codes are explained in 2.4.2.2.

The particles found on the filters after extrusion of rPE are different to the ones found in rPP samples. Only the silver-like flat particles (likely Aluminium) are similar but smaller in rPE than in rPP. The white particles found in all rPE samples are not solid at room temperature, instead they have a rubbery structure, FTIR spectra shows signatures corresponding to silicon rubber. It is unclear what the origin of these particles is, it could be the component of glues of hotmelts used in the packaging composition but it could also come from contents of packages that cannot be washed out with the mechanical recycling process used here. Silicon rubber resists high temperatures and apparently, the shear in the extruder helps to agglomerate the particles which are transported with the molten PE but are not small enough to go through the $250 \mu \mathrm{m}$ filter. Brown particles found also in all rPE samples are identified as paper by the FTIR and due to their shape, they are most likely paper fibres. Their origin is probably package parts that are not removed during the mechanical recycling. FTIR spectra can be found in Table C.4 in Appendix C). 
Table 6.8 Observations during processing of rPE flakes with different impurities and the virgin reference.

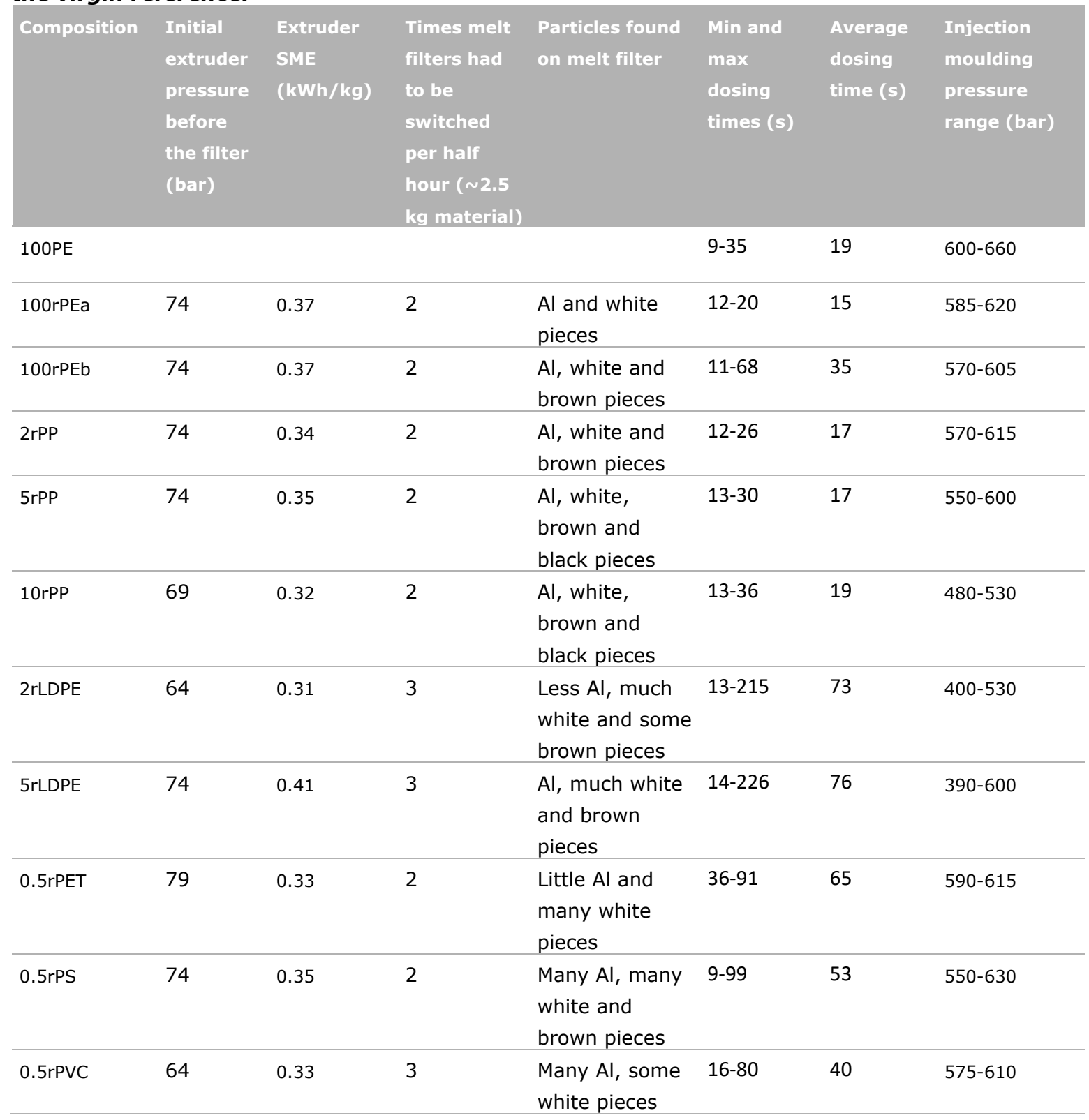

In spite of the impurities present in the $100 \%$ rPE material and the added impurities, all produced rPE samples could be sheet extruded and injection moulded. During sheet extrusion some variations in die pressure were observed but variations were small when compared to the $100 \%$ rPE and the virgin materials. Specially for the last sheet extruded samples, the pressure increased from 90 bar to 110 bar, most probably due to accumulation of materials on the filter. The filter of the sheet extrusion line contained unmelted particles, silver-like colour, most probably aluminium pieces that went through the first filtration step during extrusion.

The virgin reference material was injection moulded and sheet extruded as received from the supplier. Injection moulding dosing times were relatively long for the virgin material (around 20 seconds) when compared to the typical times for injection moulding (below 5 seconds). Dosing was not only long, it showed a huge variation from sample to sample. For samples containing impurities dosing times could vary from 9 to 99 seconds from shot to shot. For some impurities the maximum dosing time was extremely long, above 200 seconds for samples containing LDPE. These samples also showed a very large average time, larger than 70 seconds, while the reference rPE materials had average dosing times below 35 seconds as can be seen in Table 6.8 . 


\subsubsection{Polymer melt flow results}

Melt flow index was measured for the rPE samples. Results are presented in Figure 6.8.

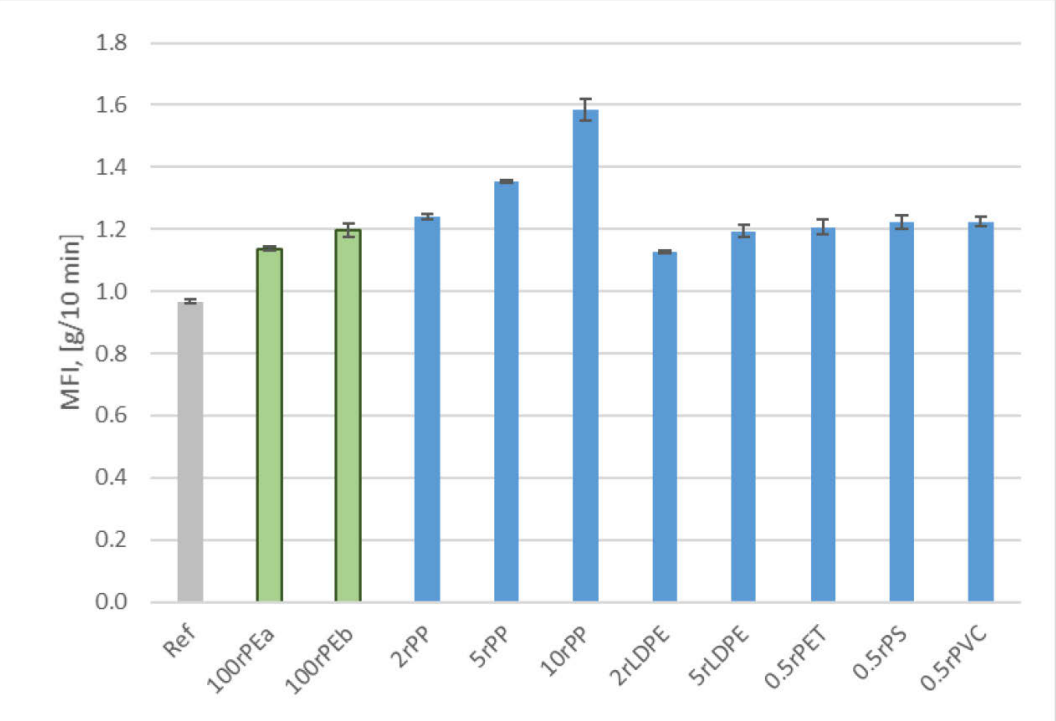

\footnotetext{
Figure 6.8 Melt flow index at $5 \mathrm{~kg}, 190^{\circ} \mathrm{C}$ of samples containing rPE and different impurities
}

The flow of PE was only affected by the addition of large amounts of PP, more than $5 \%$. The other added impurities did not significantly affect the MFI of the rPE. This is also observed in the viscosity curves measured at $250^{\circ} \mathrm{C}$. MFI is usually a single point measurement of the viscosity behaviour of the polymer. Complementary measurements such as dynamic rheometry give a better insight in the viscoelastic behaviour of the sample at different shear rates. Results of these measurements are in Appendix D, Figure D.2.

The MFI of polymers is related to their molecular weight. Very low MFI at the measured conditions (below $1 \mathrm{~g} / 10 \mathrm{~min}$ ) implies very high molecular weights. High molecular weights are related to longer chains and more physical interactions in between the chains, usually resulting in high mechanical strength of the final product but more difficult to process due to the difficult flow of the long chains. Depending on the extrusion application, MFI between 1 and $2 \mathrm{~g} / 10 \mathrm{~min}$ can be acceptable for extrusion blow moulding or other applications only when the mechanical properties are maintained.

\subsubsection{Mechanical analysis}

PE types on the market are usually designed to achieve certain impact strength making them suitable for specific applications such as blow moulded bottles or flasks. Blow moulding applications require very high impact resistance and the virgin type used here was designed for high stiffness environmental stress cracking. rPE samples produced in this research can reach values of $20 \mathrm{~kJ} / \mathrm{m}^{2}$ and as can be seen in Figure 6.9, they only decrease when rPP was added. Impact resistance is significantly lower than the virgin reference, however there might be less demanding applications where this value is sufficient. 


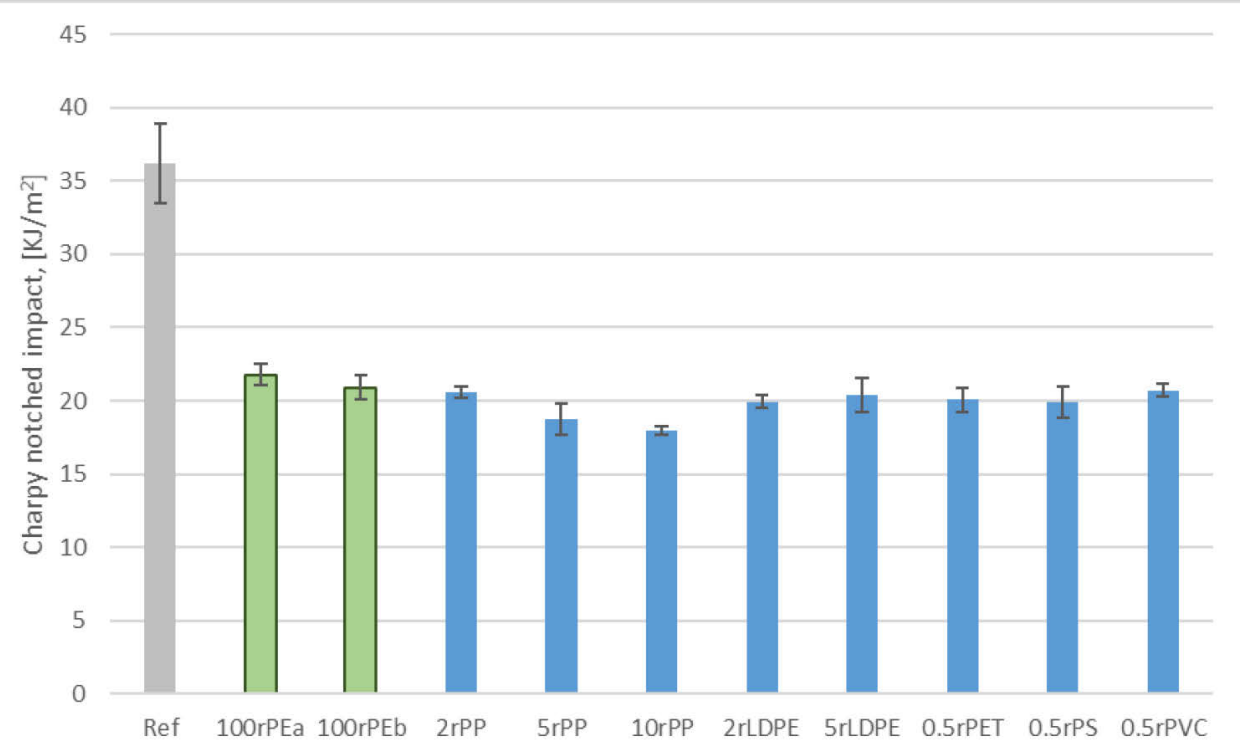

Figure 6.9 Charpy impact strength of the PE reference (grey), $100 \%$ rPE samples in duplo (green) and rPE samples with different impurities (blue)

Mechanical properties were measured on extruded sheets. Data is summarized in Table 6.9. The falling dart resistance appeared to increase when adding some of the impurities, however this was not confirmed in the tensile testing, especially E-modulus should follow a similar trend. The addition of impurities did not show increasing valued for the E-modulus, where the only significant difference was observed between the references 100PE and the rest of the rPE containing samples. Also, no difference was observed in maximum strength or elongation at break, only when comparing with the virgin reference.

Table 6.9 Mechanical properties measured in extruded sheets. Falling dart resistance and tensile properties: E-modulus, Stress max and elongation at break (EAB).

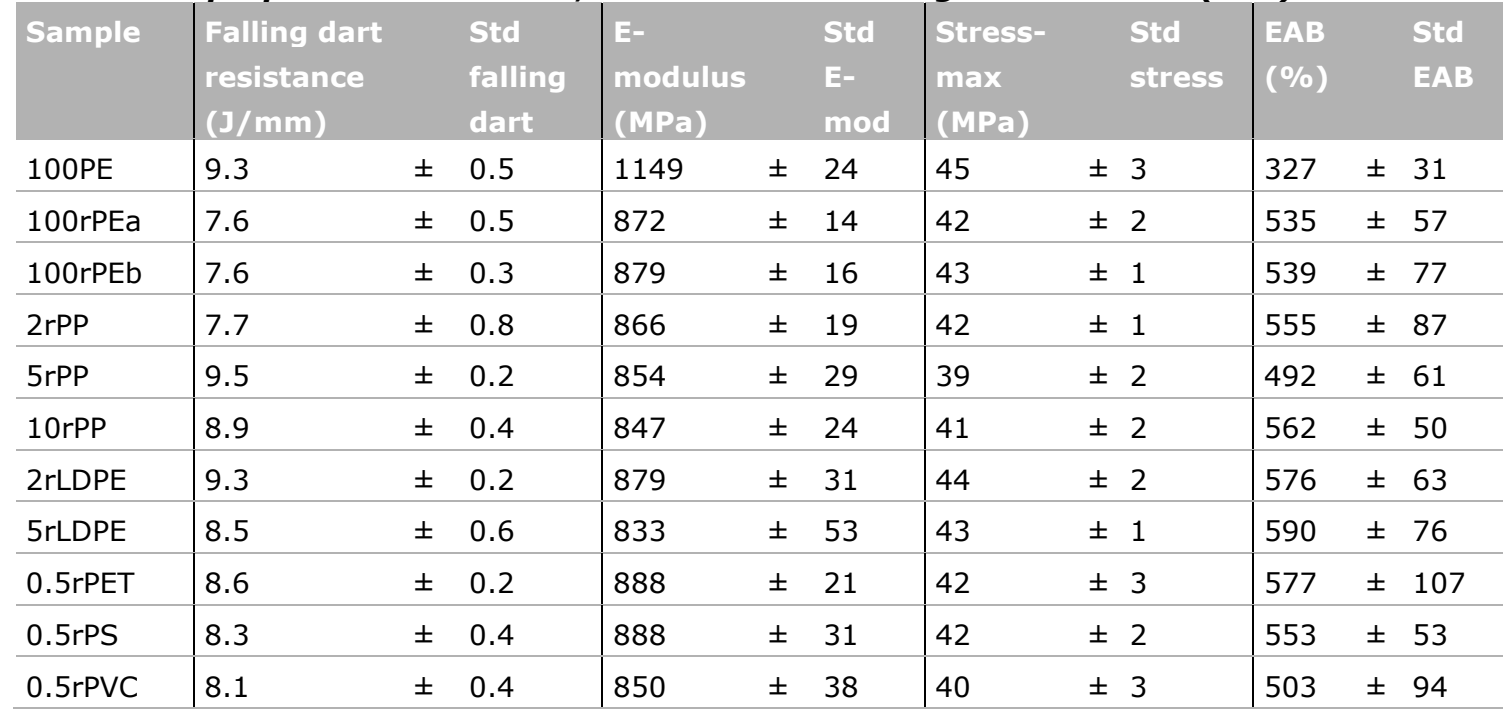

\subsubsection{Physical, chemical and thermal analysis}

The measured density of the virgin material was $939 \pm 10 \mathrm{~kg} / \mathrm{m}^{3}$. The density values for all samples containing rPE with and without impurities varied between 934 for samples containing $10 \%$ rPP as impurity and $947 \mathrm{~kg} / \mathrm{m}^{3}$ for samples containing 0.5rPVC. However the differences are small and result in an average density of $939 \pm 10 \mathrm{~kg} / \mathrm{m}^{3}$ for all samples. Impurities and presence of rPP do not have an effect on the density of the injection moulded products. 


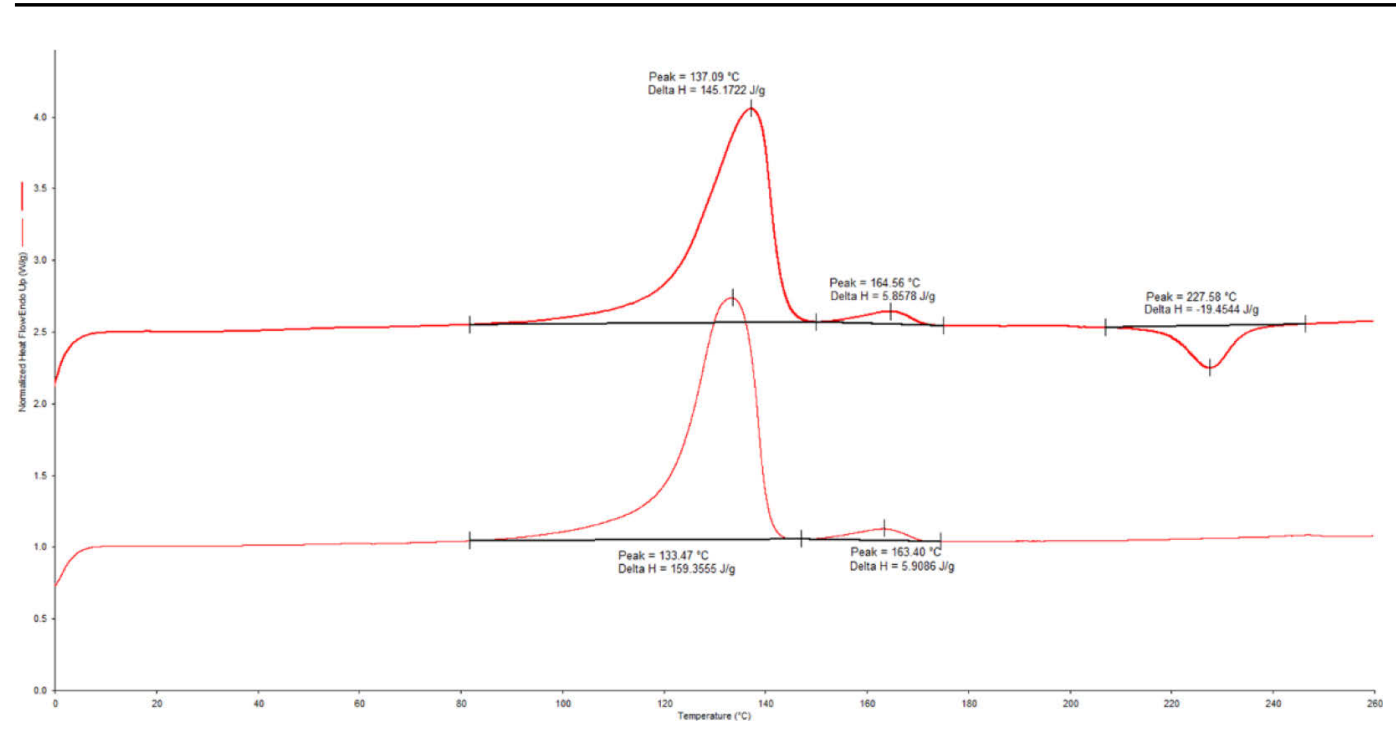

Figure 6.10 Typical DSC spectrum of a rPE sample containing PP as impurity, curve above shows the first warming up curve and curve below the second one

The PP impurities added to the rPE could be clearly identified with help of calorimetry as shown in Figure 6.10, however quantification was not possible. DSC results for all samples are presented in Table 6.10. In samples containing rPP and rLDPE a small additional peak was observed at higher melting temperatures than the PE peak. PE peak have a maximum usually around 132 to $134^{\circ} \mathrm{C}$, the additional small peak observed had a maximum around $162^{\circ} \mathrm{C}$. This temperature is usually attributed to the melting of PP, this peak was not present in the other rPE samples. The peak maximum and its enthalpy are given as Tm [PP] and $\triangle H[P P]$. It is noticeable that this peak also appears with the addition of LDPE, since usually LDPE will melt at lower temperatures than HDPE (around $115^{\circ} \mathrm{C}$ ). The appearance of a PP peak when PE is added might imply that the LDPE material used as impurity was a multilayer packaging containing also PP. The results also show that the crystallinity of samples (" $X$ "\% PE) containing rPP in rPE is lower than for the pure rPE samples and samples with other impurities. The degree of crystallinity that can be achieved with all rPE samples is lower than what can be achieved with the virgin reference, this might influence the end properties of the packaging product.

Table 6.10 Melting temperatures (Tm) and enthalpies ( $\Delta H)$ of the different peaks found in the second warming curve of rPE samples. Calculated mass percentage of PE present in the sample (\%PE) and total crystallinity of the PE fraction (X\%). T*unknown is the temperature of the exothermic peak found in the first warm up curve for all samples.

\begin{tabular}{|c|c|c|c|c|c|c|c|}
\hline Code & $\begin{array}{l}\operatorname{Tm}[\mathrm{PE}] \\
\left({ }^{\circ} \mathrm{C}\right)\end{array}$ & $\begin{array}{l}\triangle H[P E] \\
(\mathrm{J} / \mathrm{g})\end{array}$ & $\begin{array}{l}\operatorname{Tm}[\mathrm{PP}] \\
\left({ }^{\circ} \mathrm{C}\right)\end{array}$ & $\begin{array}{l}\Delta H[P P] \\
(J / g)\end{array}$ & $\begin{array}{c}\text { "X"\% } \\
\text { PE }\end{array}$ & $\begin{array}{l}\mathrm{T}^{*} \text { unknown } \\
\left({ }^{\circ} \mathrm{C}\right)\end{array}$ & $\begin{array}{l}\Delta \mathrm{H}[\text { unknown }] \\
(\mathrm{J} / \mathrm{g})\end{array}$ \\
\hline 100PE & 131 & 197 & & & $66 \%$ & 240 & -17 \\
\hline 100rPEa & 134 & 186 & & & $63 \%$ & 227 & -7 \\
\hline 100rPEb & 133 & 186 & & & $63 \%$ & 230 & -17 \\
\hline $2 \mathrm{rPP}$ & 132 & 179 & 162 & 1.3 & $60 \%$ & 231 & -21 \\
\hline $5 r P P$ & 133 & 175 & 162 & 2.1 & $59 \%$ & 229 & -24 \\
\hline 10rPP & 134 & 159 & 163 & 5.9 & $54 \%$ & 228 & -20 \\
\hline 2rLDPE & 134 & 182 & 162 & 0.4 & $62 \%$ & 229 & -24 \\
\hline 5rLDPE & 134 & 176 & 163 & 1.4 & $59 \%$ & 229 & -23 \\
\hline $0.5 \mathrm{rPET}$ & 133 & 183 & & & $62 \%$ & 230 & -17 \\
\hline $0.5 \mathrm{rPS}$ & 133 & 182 & & & $62 \%$ & 229 & -18 \\
\hline $0.5 r P V C$ & 132 & 181 & & & $61 \%$ & 220 & -22 \\
\hline
\end{tabular}




\subsubsection{Colour characterization}

Samples containing post-consumer rPE are non-white since they were not colour-sorted. Darker colours are prominent from the lower $L^{*}$ values shown in Table 6.11 when compared to the reference material. Furthermore, all samples containing rPE show a more green tone (negative a*) and high yellow values (positive $b^{*}$ ). The largest differences when comparing the samples with impurities to the $100 \%$ rPE samples are observed for the smallest amount of impurities: $0.5 \%$ PET, PS and PVC as can be seen in Figure 6.11. PS and PET can probably be explained by the colour of the added packaging; for PS it was one type of packaging with lots of ink printed colours. However for PVC, it seems to be the effect of degradation resulting in a larger difference in colour than when only PE, or PP are present.

Table 6.11 Measured colour of the virgin HDPE reference material and the produced rPE samples.

\begin{tabular}{|c|c|c|c|c|c|c|c|}
\hline $\begin{array}{l}\text { Sample } \\
\text { code }\end{array}$ & L* & & & a* & b* & & $\Delta E$ \\
\hline Ref & 79 & \pm & 1 & $-0.9 \pm 0.1$ & -2.3 & \pm 0.2 & \\
\hline 100rPEa & 62 & \pm & 2 & $-4.5 \pm 0.3$ & 7.0 & \pm 0.3 & \\
\hline 100rPEb & 60 & \pm & 2 & $-4.7 \pm 0.2$ & 6.5 & \pm 0.2 & \\
\hline $2 r P P$ & 60 & \pm & 1 & $-4.9 \pm 0.4$ & 6.5 & $\pm \quad 0.2$ & 0.4 \\
\hline 5rPP & 60 & \pm & 1 & $-4.5 \pm 0.5$ & 6.3 & \pm 0.3 & 0.7 \\
\hline 10rPP & 59 & \pm & 1 & $-4.7 \pm 0.2$ & 6.6 & $\pm \quad 0.4$ & 1.9 \\
\hline 2rLDPE & 60 & \pm & 2 & $-4.9 \pm 0.2$ & 7.0 & $\pm \quad 0.4$ & 0.8 \\
\hline 5rLDPE & 60 & \pm & 2 & $-4.8 \pm 0.1$ & 6.4 & \pm 0.5 & 0.7 \\
\hline 0.5 rPET & 60 & \pm & 1 & $-3.2 \pm 0.3$ & 8.5 & \pm 0.3 & 3.1 \\
\hline $0.5 \mathrm{rPS}$ & 58 & \pm & 2 & $-2.6 \pm 0.4$ & 10.2 & \pm 0.2 & 11.2 \\
\hline $0.5 r P V C$ & 59 & \pm & 1 & $-1.4 \pm 0.4$ & 8.8 & \pm 0.3 & 9.6 \\
\hline
\end{tabular}

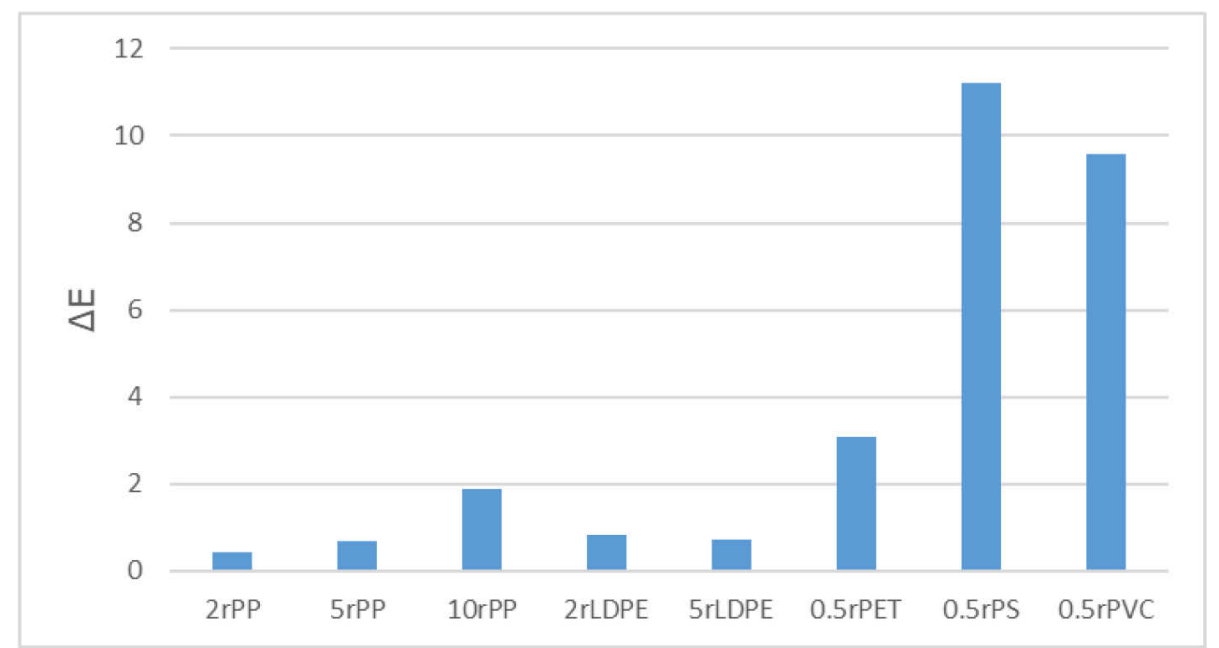

Figure 6.11 Colour difference between the samples with impurities and the reference $100 \%$ rPE material 


\section{Discussion}

In the discussion first the results of this study are compared with those in the scientific literature (7.1). In the next part (7.2) we evaluate the analysis methods for recycled plastics . Section 7.3 focuses on the comparison of the commercially available recycled pellets versus the recycled pellets made in this project. In 7.4 several pathways towards more circularity are described.

\subsection{Comparison of the results with scientific literature}

The scientific literature on the nature and properties of recycled plastics is not abundant. The most relevant technical insights are shortly introduced here and compared with the results of this project.

In 2008 Vilaplana and Karlsson described three common quality loss mechanisms which occur in recycled plastics; thermo-oxidative degradation, particle contamination and low molecular weight contamination [Vilaplana and Karlsson, 2008]. Heating in the presence of oxygen causes chain scission reactions in most polymers (such as PP and PET), cross-linking reactions in LDPE, crosslinking and branching reactions in HDPE and additionally decomposition reactions in polymers such as PVC and PVOH. All these reactions will impact the material properties of the recycled plastics (MFI, tensile strength, colour, etc.) of which some strongly relate to the molecular architecture of the recycled plastics (MFI, viscosity). The particle contamination originates both from solid particles like sand, clay, textile fibres, dust and also from polymeric impurities that do not mix with the main polymer. The low molecular weight contaminants originate from product residues (fats, fragrants), absorbed odours, additives, decomposed additives and decomposition products from the polymer itself. Every type of recycled plastic suffers from the three quality loss mechanisms in different ratios. Recycled PE and PP made from post-consumer packaging waste are likely to suffer the most from particle and molecular contaminants. Since the life time of a package is usually only a few months, thermo-oxidative degradation is expected to have a limited effect.

In the current study polymeric impurities have been added in known quantities to recycled plastics with a high level of polymeric purity, in order to quantify the impact of impurities on the processability, material properties and finally also product properties.

\subsubsection{Recycled materials as blends}

Although Brandrup already reported in 1996 that recycled plastics are often blends of polymers, little compositional data on recycled plastics was available [Brandrup, 1996]. In 2014 Luijsterburg and Goossens reported for the first time that rPE and rPP are in fact blends of polymers. Based on thermal and infrared measurements they concluded that Dutch post-consumer packaging waste PE which was mechanically recycled in a laboratory is primarily composed of PE (80-97\%), contains some PP (2$10 \%)$ and small amounts of other polymers such as PET (1-5\%). Similarly, rPP made from Dutch postconsumer packaging waste is primarily composed of PP (93-98\%), PE (1-2\%) and some PET (1-6\%) [Luijsterburg and Goossens, 2014]. In 2017 Kamleitner et al. reported that commercial Austrian rPP is composed of about $90 \%$ PP and $10 \%$ rPE [Kamleitner et al. 2017]. At the same time, Thoden van Velzen et al. reported that laboratory recycled Dutch PE is composed of $90 \% \mathrm{PE}, 8 \% \mathrm{PP}$ and small amounts of PET, PS, PVC, black plastics and residual material based on NIR- sorting of washed milled goods [Thoden van Velzen et al., 2016]. In 2018 the same research group reported on the composition of Dutch rPE and rPP, both modelled and verified with NIR-based sorting of commercial and laboratory produced washed milled goods [Brouwer et al., 2018]. According to this analysis Dutch rPE from separate collection consists of approximately $91 \% \mathrm{PE}, 8 \% \mathrm{PP}, 0.4 \%$ black plastics, $0.3 \%$ PVC, $0.2 \%$ PS, $0.2 \%$ PET and $0.1 \%$ paper. Furthermore, Dutch rPP from separate collection consists of approximately $91 \% \mathrm{PP}, 5 \% \mathrm{PE}, 3 \%$ black plastics, $1 \% \mathrm{PS}, 0.2 \% \mathrm{PVC}$ and $0.1 \%$ paper [Brouwer et al., 2018]. 
The polymeric composition of the commercial rPP and rPE products studied here was compared to the previously reported compositions and they are in fairly good agreement (see section 5.1), even though some of the studied samples originate from industry and other samples from research laboratories. Hence, industrially produced post-consumer PP flakes are composed of mostly PP (92$94 \%$ ) and some PE (3-4\%) and small amounts of minor impurities varying in nature. Additionally, industrially recycled post-consumer PE flakes consist of $90-95 \%$ PE, 2-7\% PP, 1-4\% Black plastics and several sub-percent impurities. Of these, most were polymeric impurities. Only in case an advanced mechanical recycling process is used, the polymeric purity can reach levels of about $95 \%$. In general, post-consumer recycled PE and PP are always blends.

In a review article in 2017, Ragaert et al. described the polymeric compositions of recycled polymers in a theoretical framework. Since post-consumer recycled plastics usually contain a polymeric impurity in concentrations exceeding $2 \%$, they form blends. Blends of different polymers are usually immiscible. The two main polymers (PE and PP) present in both rPE and rPP, also form an immiscible blend. Typically, the blend morphology is determined by the concentration of polymer present, miscibility and compatibility of the two polymers and processing variables such as temperature and shear forces which, in turn, determine the dispersion of the second immiscible polymer in the matrix of the main polymer. This blend morphology will in turn determine the material properties. For polyolefin blends mechanical properties such as tensile strength follow the additive law of mixing (this implies that the property of the blend relates in proportional manner to the properties of the pure polymers). Whereas, impact strength and elongation at break relate to interfacial tensions and are more sensitive to the distribution and dispersion of the second polymer [Ragaert et al. 2017].

In our study, a mild antagonistic mixing behaviour of the Charpy impact strength property was observed for the addition of rPP as impurity to $\mathrm{rPE}$, significant only when 5 and $10 \% \mathrm{rPP}$ is added (Figure 6.9). The addition of rPE as impurity to rPP (Figure 6.4) follows the additive law of mixing, resulting in an increased Charpy impact strength due to the higher impact of the rPE material itself. The blending of different types of polymers and the presence of active additives in the rPE and rPP will influence the blend behaviour. For the other added polymers (PET, PS, PVC), though they are also immiscible with the matrix material, the amounts added were so low $(0.5 \%)$ that no effects were observed in the impact strength when compared to the $100 \%$ rPE or rPP. Additionally, PVC can degrade at the temperatures at which PE and PP are processed. Consequently hydrochloric acid is formed, which can catalyse degradation reactions of PE and PP. However, this effect was not observed neither in the mechanical strength nor in the melt flow properties of the studied blends.

On top of the current knowledge from literature, this study has delivered new insights in the properties of recycled plastics. The properties of recycled post-consumer polyethylene and polypropylene are not only determined by the polymeric composition but also by the distribution of polymer types present. These polymer types vary on molecular structure (homo, co-polymer), molecular weight, molecular orientation (tacticity) and molecular architecture (branching). Virgin plastics are usually well defined polymeric structures with relatively well-defined molecular properties. Additionally they often contain dedicated additives to optimise their performance for a specific application. Some of the commonly used types of additives are processing aids, anti-oxidants, UV stabilizers, pigments, nucleation agents, impact modifiers, fillers, and fire retardants.

In recycled plastics, potentially multiple grades of a polymer type are present, resulting in a much broader molecular weight distribution. In case of polyethylene there are a number of different grades on the market with different molecular architectures, such as LDPE, LLDPE, HDPE which are all present in post-consumer PE. Similarly, for polypropylene, there are homopolymers, copolymers and polymers with different tacticity. All these different grades are combined in post-consumer PP. Both types of polymer grades present and the molecular weight distribution affect the material properties of the recycled plastics in a complex manner that is not well-understood, yet. Next to the mechanical properties, melt flow properties of the materials are strongly affected by the molecular structure of the polymer, for example MFI and viscosity. Furthermore, the use of organic and inorganic additives to improve flow, thermal stability, reduce oxidation, increase UV stability, change colour, increase strength, etc. is common practice when developing a plastic packaging product. All these additives are 
also present in post-consumer plastic waste and consequently also in rPP and rPE. Since rPE and rPP should be considered as mixtures of polymer types with different additives it complicates this study to find relations between added polymeric impurities and fundamental polymer properties such as crystallinity.

In this study, clear differences are observed between the mechanical and melt flow properties of dedicated virgin materials and the recycled plastics of high polymeric purity. This reconfirms that virgin plastics are tailor-made for specific applications and have concomitant mechanical and flow properties, whereas recycled plastics with a high polymeric purity are mixtures of grades and additives with average mechanical and flow properties.

\subsubsection{Processing}

The presence of small amounts of other polymers that melt at different temperatures than the matrix material (PA, PET, silicon-rubbers, etc.) will largely affect the quality of products made from rPP or rPE and complicate the conversion processes [Ragaert et al, 2017]. All these unmelted polymers will not mix with either PE or PP and will form small particles in the matrix that either will remain on the melt filter -as observed in this study- or in case of the melt filter is absent or has a larger mesh than the particle size, they will strongly influence the mechanical properties of the final product and form defects or weak spots in the final product.

More specifically, the large difference in melting temperatures between PET and PE will impact the process. In the current research the following has been observed: if PP recycled plastic is processed at the relative high melting temperature of PET, in a second processing step thermo-mechanical degradation will affect directly the mechanical properties (see results for PP, sample PET-HT). Flow properties seem to remain the same. Processing at lower temperatures, which are more common for $\mathrm{PP}$ or PE, will result in the clogging of melt filters, which therefore will need to be replaced much more often, which will result in material losses as observed in this study.

\subsection{Analysing recycled plastics}

The polymeric composition and melt flow properties of recycled polyethylene and polypropylene can both be characterised effectively with different techniques. The pros and cons of those different analysis techniques for both polymeric composition and melt flow properties are discussed separately in this section.

\subsubsection{Polymeric composition of recycled plastics}

The polymeric composition of recycled plastics can be assessed with multiple different methods depending on the processing stage (washed milled good, extruded pellets, test specimen and produced articles). All methods have their pros and cons and these are summarised in Table 7.1. The major benefit of NIR-based flake sorting is the wide concentration range in which impurities can be quantified. The major downside is that black plastic flakes cannot be identified and form a separate group of un-identified flakes.

For pellets, test specimens and produced articles two methods are available: thermal analysis (DSC) and infrared spectroscopy (FTIR). Both techniques are semi-quantitatively and cannot quantify several common polymeric impurities such as PS and PVC [Luijsterburg and Goossens, 2014].

Additionally, the residues on the melt filter can be analysed with FT-IR-ATR to render a qualitative impression of the non-melting impurities that are present in the melted recycled plastic. Since these residues are often a few milligrams that originate from a few kilograms of extruded material, it yields an impression of these non-melting impurities in the low concentration ranges. 
Table 7.1 Laboratorium methods to assess the polymeric composition of recycled

plastics.

\begin{tabular}{|c|c|c|}
\hline $\begin{array}{l}\text { Method / type of } \\
\text { recycled plastic }\end{array}$ & Advantages & Disadvantages \\
\hline $\begin{array}{l}\text { NIR Flake sorting / } \\
\text { Flakes }\end{array}$ & $\begin{array}{l}\text {-Almost all polymers can be } \\
\text { quantified (besides black plastics) } \\
\text {-Wide concentration range ( } 0.01 \text { - } \\
100 \% \text { ) } \\
\text {-NIR is a well-known technique in } \\
\text { the industry }\end{array}$ & $\begin{array}{l}\text {-Laborious } \\
\text {-Multiple samples need to be analysed for } \\
\text { representative result } \\
\text {-Black plastics cannot be analysed }\end{array}$ \\
\hline $\begin{array}{l}\text { FT-IR-ATR / pellets, } \\
\text { test specimen or } \\
\text { produced article }\end{array}$ & $\begin{array}{l}\text {-Relatively fast analysis } \\
-\mathrm{PE}, \mathrm{PP}, \mathrm{PET}, \mathrm{PA} \text { can be quantified } \\
\text { when present at concentrations in } \\
5-100 \% \text { range }\end{array}$ & $\begin{array}{l}\text {-Semi-quantitatively } \\
\text {-Not sensitive below } 5 \% \\
\text {-PS, PVC, POM are difficult to analyse } \\
\text { - FTIR is less known within the recycling } \\
\text { industry }\end{array}$ \\
\hline $\begin{array}{l}\text { DSC / pellets, test } \\
\text { specimen or produced } \\
\text { article }\end{array}$ & $\begin{array}{l}\text { - Relatively fast analysis } \\
\text {-PE, PP and PET can be quantified } \\
\text { at concentrations in } 5-100 \% \text { range }\end{array}$ & $\begin{array}{l}\text {-Semi-quantitatively } \\
\text {-small sample ( } 15 \mathrm{mg} \text { ) per analysis, if mixing } \\
\text { is not proper, large variations in results are } \\
\text { expected. } \\
\text { - Quantification is done based on the amount } \\
\text { of measured crystallinity. If impurities and } \\
\text { blending influence the degree of crystallinity, } \\
\text { quantification is inaccurate. } \\
\text {-PS, PVC do not show phase transitions that } \\
\text { can be used to quantify them. } \\
\text {-Due to the knowledge required to understand } \\
\text { and analyse the data, this technique is not } \\
\text { suitable in the industry for quick quantitative } \\
\text { screening }\end{array}$ \\
\hline $\begin{array}{l}\text { Visual analysis + FT- } \\
\text { IR-ATR / melt filter } \\
\text { residu }\end{array}$ & $\begin{array}{l}\text {-qualitative analysis of minor } \\
\text { impurities in recycled plastics that } \\
\text { do not melt } \\
\text { - Visual analysis of the industrial } \\
\text { melt filters can already render } \\
\text { information on impurities }\end{array}$ & $\begin{array}{l}\text { - Laborious } \\
\text { - Not quantitatively } \\
\text { - FTIR is required to identify impurities }\end{array}$ \\
\hline
\end{tabular}

In chapter 5 industrial flakes of recycled PP and recycled PE have been analysed by NIR-based flake sorting and the corresponding pellets by DSC. For the recycled PP, flake sorting results in a polymeric purity of $92-94 \%$, with $3-4 \%$ PE, 1-4\% black plastics and minor (sub-percent) amounts of PET, PS, PVC. DSC analysis of the corresponding pellets yielded a PE content of 7-9\%, assuming the present impurities do not influence the crystallinity of the PE. Likewise, for the recycled PE, flake sorting results in a polymeric purity of $90-93 \%$, with 3-7\% PP, 1-4\% black plastics and minor (sub-percent) amounts of PET, PS, PVC and PA. DSC analysis of the corresponding pellets yield a PE content of 87$93 \%$. The results of the NIR-based flake sorting and the DSC are in fairly good agreement to each other, especially since the flakes still contain substantial amounts of black flakes that are likely to be either PE or PP. All three methods reveal that the recycled polymer contains polymeric impurities. Only with NIR flake analysis small percentages of these impurities can be quantified accurately. With FT-IR and DSC only a limited amount of polymeric contaminants can be determined, the sensitivity is limited and the error is too large for accurate quantification.

\subsubsection{Melt flow properties}

In this project three different methods have been used to measure melt flow properties of a material. These methods are discussed in this section. 
MFI is a common parameter used in the plastic industry to assess the suitability of a polymer for a certain application. The higher the MFI value, the better the flow in the matrix and therefore the possibility to mould more complex forms or create thinner walls. For example, for PE low MFI values (usually below $2 \mathrm{~g} / 10 \mathrm{~min} @ 190^{\circ} \mathrm{C} / 5 \mathrm{~kg}$ ) are indicative that the grade is suitable for extrusion blow moulding and other extrusion applications. For injection moulding applications, substantially higher MFI values are required (usually above $10 \mathrm{~g} / \mathrm{min} @ 230^{\circ} \mathrm{C} / 2.16 \mathrm{~kg}$ ).

In this study, the MFI parameter was found to be a sensitive indicator for the presence of polymeric impurities. Polymeric impurities were added to recycled plastics with a high polymeric purity and this resulted in clear changes in the MFI value. Also the clear difference between the MFI values of the tailor-made virgin polymers and those of the recycled plastics with a high polymeric purity are striking. The tailor-made virgin plastics have, as expected, dedicated flow properties which match with their intended use. The highly pure recycled plastics are composed of a mixture of different grades of polymers which previously had different intended uses and therefore the MFI values can only reach a certain maximum that is strongly influenced by the presence of impurities.

A measurement technique very close to the processability and applicability of polymers is spiral flow. This is a very well-known evaluation method in the injection moulding industry. It gives a direct impression of the applicability of the material. In this study, we have shown that spiral flow results for PP correlate very good with the MFI measurements, both are sensitive to the presence of impurities.

The third technique used was rotational viscometry, this technique yields extra information on the polymer viscoelastic behaviour and is strongly related to the molecular weight distribution, cross linking and present impurities. However, due to the complexity of a recycled plastic, and the small differences observed in the data, detailed analysis and interpretation was not pursued further. These data is certainly interesting in a follow up research from the scientific point of view.

\subsection{Properties of recycled PE and PP pellets}

In this study rPE and rPP with two different origins were analysed; commercial recycled pellets (chapter 5) and recycled plastics created for this project (chapter 6). The properties of both types of samples are compared in section 7.3.1. In 7.3.2, other properties of recycled PE and PP are discussed in a more general way.

\subsubsection{Commercial vs. high purity recycled plastics}

The properties of the commercial recycled plastics vary substantially from sample to sample as is apparent from their MFI and colour values. Nevertheless, the measured values are in agreement with the supplied information in the data sheet. The variation in the colour values is most probably related to a variation in the sorting or the compounding at the recycling facility. Some recycled plastics have been subjected to colour sorting of the washed flakes. Additionally, some recyclers specifically add colour master batches to render the recycled plastic a defined colour. The variation in MFI values for the commercial recycled PP products is substantial (between 12 and $50 \mathrm{~g} / 10 \mathrm{~min} @ 230^{\circ} \mathrm{C}$ and 2.16 $\mathrm{kg}$ ), it is likely that this property has been tuned by either adding specific additives or modifying the process.

The best achievable melt flow index for the recycled PP with a high polymeric purity was 22-23 g/10 min. at $230^{\circ} \mathrm{C}$ and $2.16 \mathrm{~kg}$. With exception of the PP sample containing in-mould labels as an impurity, which had MFI values higher than the reference sample. Higher MFI values of the commercial samples indicate the use of additives and lower values most probably indicate the presence of impurities in the commercial samples. Commercial rPPs have polymeric purities of 92 $94 \%$, degrees of crystallinity varying between 33 and $38 \%$, whereas the recycled PP with high polymeric purity of about $99.5 \%$ has a higher degree of crystallinity of $42-43 \%$. 
The commercial recycled PE products have polymeric purity levels of $90-95 \%$ and MFI values of 1.5 $1.8 \mathrm{~g} / 10 \mathrm{~min} @ 190^{\circ} \mathrm{C}$ and $5 \mathrm{~kg}$ whereas the recycled PE with $99.5 \%$ polymeric purity has a lower MFI value of $1.1-1.2 \mathrm{~g} / 10 \mathrm{~min} @ 190^{\circ} \mathrm{C}$ and $5 \mathrm{~kg}$. Most probably, the presence of PP in the commercial samples explains this increase in MFI.

\subsubsection{Factors influencing processing and properties of rPE and rPP}

The addition of impurities to the recycled plastics with a high polymeric purity had implications for the processability and material properties, as explained in chapter 6 . Especially the addition of non-melting impurities complicates the processing (section 7.1.2). The recycled plastics that were carefully prepared to be $99.5 \%$ pure at object level, were still found to contain about $0.5 \%$ other polymers and materials on the flake level. Some of this was PE in PP and PP in PE. According to the observations of the melt filters used for PP processing, several non-melting impurities are still present in the flakes at very low concentrations, namely: aluminium, PET, nylon, paper and silicon. This suggests that the targeted packaging components still contain small amounts of other materials. For trays, this can be related to fragments of top-sealed aluminium and / or plastic film. There might even be very thin PET and nylon barrier layers present in the packages, that are not detectable with the NIR scanners and are only detectable as residues on the melt filter. In the case of PE, also aluminum was observed on the melt filters, paper and some silicon rubber, most probably materials that could not be removed during the washing process.

In summary, this study suggests that the processing and properties of recycled PE and PP are influenced by three factors:

1) Polymeric composition: blends of different polymer grades of the same polymer type,

2) Presence of impurities: relates both to the presence of polymeric contaminations in concentrations that vary between $10 \%$ and the sub-percental level and also to other materials such as aluminium, silicon, paper fibres, etc.,

3) Presence of additives: commonly used types of additives in the packaging industry such as processing aids, anti-oxidants, UV stabilizers, pigments, nucleation agents, impact modifiers, fillers, and fire retardants, etc.

This explains that recycled PP and PE - even if it has a high polymeric purity - always will have different properties compared to virgin material. This will be further discussed in the next section.

\subsection{Towards more circularity}

This study has rendered new insights in the nature of recycled post-consumer PP and PE and in their properties. First of all, this study has revealed which impurities are most common in recycled PP and PE made from post-consumer packaging waste and how these impurities affect the processability and material properties. Additionally, this study has shown that not only the polymeric impurities determine the mechanical and flow properties, but also the types of polymer grades present in the recycled material. Any comparison between a virgin polymer and a recycled plastic is hampered by the fact that virgin polymers are sold as tailor-made grades with specific properties to suit their use. Therefore, post-consumer recycled plastics are in their very nature a mixture of different tailor-made grades with consequently average properties. Although the properties of recycled plastics can be modified to some extent by the use of additives, this fundamental difference between virgin and recycled polymers is disadvantageous for recycled plastics in general and especially when more demanding applications are considered (such as thin-walled and high strength objects). Given this complex situation, three pathways towards a higher level of circularity for PE and PP are foreseen, which are discussed in the sections below. A higher level of circularity in this context is understood as broadening the application range of the existing post-consumer recycled plastics. 


\subsubsection{Stricter quality control within the current recycling system}

One of the most straight-forward improvement options for the current recycling system is assuring full compliance to the current quality specifications for sorted products, specifically for DKR 329 and DKR 324. Most representatives of recycling industries (section 3.1.1) regard this as the most important improvement option. In case the sorted products would comply to a larger extent to the current specifications, the recycled plastics would contain less polymeric impurities, they would be more easy to process and have better and less varying flow and mechanical properties.

The quality of recycled plastics could be even further improved with stricter quality specifications on sorted products and optionally also quality standards on intermediates such as washed milled goods. Making more quality differentiations helps the trade in sorted products and intermediates. These new quality standards should be based on measured concentration limits of impurities in the washed milled goods with respect to their applicability. These limits could subsequently be translated in levels of faultily sorted articles in sorted products, but also in non-targeted packaging articles and packaging components that could negatively influence the properties required for the intended application. Hence, more stringent specifications for the sorted products could be determined.

Additional design-for-recycling measures by the FMCG industry would improve the quality of the recycled materials even further, since this would reduce the amount of design-related polymeric impurities that originate from the minor packaging components.

\subsubsection{Enhancing applicability of existing recycled plastics}

The applicability of recycled plastics can be enhanced by tuning the properties of the recycled plastics through the use of additives, advanced processing techniques or by design-from-recycling.

At the moment, using additives is the most commonly followed strategy by the recycling industry. This approach still has its limitations. For instance, it is possible to create several dedicated injection moulding grades from rPP by adding varying amounts of peroxides to degrade the PP chains in varying levels and to obtain different molecular weights. However, it is currently still impossible to create a blow-moulding grade from rPP since it would need to require chain extension to lower the MFI sufficiently.

Advanced processing technologies are currently being introduced in the market. For example Krauss Maffei is introducing compounding and post-processing technologies where gas stripping is possible, this would result in increased removal of volatiles from the molten polymers and perhaps less impurities and better controlled properties in the end pellet product [Popel, 2019].

Another strategy to enhance the applicability of the recycled plastics is design-from-recycling. With this strategy, the above-mentioned approaches are combined to make the best possible recycled pellet for a final product. Typically, the use of compatibilizers is combined with altered processing conditions. This typically involves development work which utilises compatibilizers, mixtures with virgin materials, optimization of processing conditions in the application process, i.e. injection moulding, extrusion blowing, etc. A good example of design-from-recycling is the dedicated tape extrusion process in which recycled PP is mixed with a compatibilizer and follows a modified extrusion and solid-state drawing process to obtain a markedly better quality [Luijsterburg et al. 2016]. Additionally, a plausible option will be to alter the design of the final product, making use of the properties of the recycled pellets to design a suitable process and a suitable product. For example, minimizing the use of complex shapes such that a lower MFI compound can be also injection moulded in the same shape or accept the variability in the colour of the product.

Design-from-recycling strategies would greatly benefit from more transparency in the whole plastic chain. Increased transparency, more alignment between all stakeholders in the plastic chain and more public research would boost the circular economy of plastic packaging waste. 


\subsubsection{A new system based on advanced sorting technologies}

To produce a range of high-performance recycled plastics suitable for circular applications such as packages and related consumer articles, advanced sorting technologies are required. To sort recycled plastics not only on the main type of polymer, but also on the grade, either advanced optical sorting technologies are required [Engelshoven van et al., 2019] or the packages need to be marked [Polymark, Prism, Holy Grail, Bezati et al. 2011] and technologies have to be available for their sorting. Both approaches can result in recycled plastics that are sorted both on the main type and the grade of polymers. This would enable the creation of a new recycled PE that would have sufficient high impact strengths to make bottles and jerry cans for household chemicals and chemical wastes. Likewise blow moulding grades for PP bottles are becoming possible with those technologies. Both technologies can also be relevant in order to differentiate between food- and non-food-grade plastic packages and hence to fulfil the EFSA criteria to prove that the PE or PP based recycled plastic is completely made from previously food-grade plastics.

Implementing these kind of technologies would require a complete change of mentality and large investments along the whole packaging and recycling chain.

Regardless of which pathway towards more circularity is chosen the technological innovations need to be supported by legislation. The current legislation focusses on a quantitative performance indicator named recycling rate. Achieving a more circular economy for plastic packaging waste requires the legislation not only to set quantitative targets but also targets that improve the quality of the recycled materials. Since, targets that would improve the quality of the recycled materials are likely to reduce the recycling rates, such new legislation needs to be well considered. 


\section{Conclusion and recommendations}

Currently, there is a mismatch in the supply and demand of recycled post-consumer plastics. Potential clients search for highly pure recycled plastics for competitive prices to replace virgin plastics. The recycling facilities supply a small amount of highly pure recycled plastics and larger amounts of more impure recycled plastics. The highly pure recycled plastics are relatively easy to market, but aren't and will not (soon) be food grade. The less pure recycled plastics have reduced properties and are more difficult to market. This project studied the quality of post-consumer recycled PE and PP (rPE and rPP) in relation to impurities that regularly occur in these recycled plastics to deepen our understanding of the quality of these recycled plastics and their applicability.

Several types of commercial rPE and rPP available in the market have been analysed. All received rPP samples (flakes or pellets) have a purity in the order of $90-95 \%$. They contain more than $3 \% \mathrm{PE}$ and several sub-percental polymeric and other materials impurities. The rPE samples have a similar purity, with PP as main impurity. The measured properties (MFI and colour) match with the specifications as reported in the corresponding datasheet.

rPE and rPP washed milled goods with a high polymeric purity (high purity rPE and rPP) were manually prepared in the lab by rigorous sorting on the object level and subsequent mechanical recycling. Polymeric purity levels of more than $99.5 \%$ can be attained. The preparation of the high purity rPE and rPP samples is laborious and very difficult to achieve on an industrial scale. Furthermore, this material contains different grades of the target polymer and unknown amounts of additives coming from different types of post-consumer packages and packaging components.

Based on the impurities found in the commercial samples, different common polymeric impurities (PET, PS, PVC, flexibles) were added in different realistic amounts varying from 0.5 to $10 \%$ to the high purity samples. This results in relatively small variations of the measured properties.

Main findings for the effect of impurities on the properties of rPP:

- Clear reduction in the processability with presence of $0.5 \%$ PET or $0.5 \%$ metallised film (melt filters in extrusion process are clogged).

- Maximum flow (MFI) that can be achieved with rPP is limited to what we call medium flow region $\left(\sim 20 \mathrm{~g} / 10 \mathrm{~min}\right.$ at at $\left.230^{\circ} \mathrm{C}\right)$. HDPE and LDPE even in small amounts decrease the MFI of the rPP materials. This is also true for most of the other added impurities but the effect is smaller. Samples where $50 \%$ of the bodies are replaced by bodies with in-mould labels (50IML) show a reversed behaviour, MFI increases compared to $100 \%$ rPP.

- All rPP samples have a green/grey colour, stemming from the different packages and inks used in the recycled packages. Colour gets darker when PET or in-mould labels are present.

- The thermomechanical behaviour, melting temperature and degree of crystallisation hardly change by adding impurities to rPP. This suggests that these parameters are mostly related to the different types of PP grades that are present in the matrix and not to added impurities.

- The presence of HDPE as impurity improves the impact strength.

Main findings for the effect of impurities on the properties of rPE:

- The melt flow clearly increases with 5 and $10 \%$ of rPP added to the recycled PE.

- Impact strength decreases when rPP is present in amounts higher than $5 \%$ in rPE.

- Impurities such as PS, PET and PVC strongly influence the colour of the recycled samples.

The largest differences however are observed when comparing the recycled materials to the virgin materials. As was discussed in section 7.4, any comparison between a virgin polymer and a recycled plastic is hampered by the fact that virgin polymers are sold as tailor-made grades with specific properties to suit their use. Post-consumer recycled plastics are in their very nature a mixture of different tailor-made grades with consequently average properties. This situation is - besides legal and business barriers - an important reason for the current mismatch in supply and demand of 
recycled material. To overcome this challenging situation and achieve a higher level of circularity for $\mathrm{PE}$ and PP, several options are possible.

\section{Stricter quality control within the current recycling system}

First of all, design-for-recycling of packaging in combination with better compliance to existing specifications of the sorted products will reduce the amount of impurities present in the washed milled goods and consequently in the pellets. Moreover, the introduction of quality specifications on intermediate products such as washed milled goods could also enhance the quality of the produced pellets. Positive NIR sorting of washed milled goods would certainly reduce the amount of impurities and increase the quality. However, it will reduce the produced volumes and increase the amount of discarded materials. Reduction of impurities such as PET, will result in more stable processing and flow properties of rPP. Specifications will have to be realistic and measurable. This study can be used as a first exploration. However, to create formal specifications (for example \%PET less than $0.5 \%$ ), more in-depth research is needed with more sample variations (to decide on the limits and the combined effects of impurities) and more information from the industry needs to be gathered regarding critical values for processability.

Melt filters contribute to increase the purity of the pellets. Additional purity specifications could be set for pellet materials, however, many relevant impurities are present in the washed milled goods in low concentrations and they can hardly be detected in the pellet materials. In this study only impurities present in pellets in amounts larger than $5 \%$ from a different polymer could be clearly identified with two of the used techniques: FTIR and DSC. Both techniques are hardly applicable in industry. Furthermore, a problem that cannot be solved with the current state of the art techniques is the presence of different grades of the same polymer, not only for the target polymer but also for the impurities (for example LDPE films in rPE) are impossible to distinguish at flake level and difficult to identify in a pellet. This study shows that melt flow is sensitive to the presence of impurities and defines also the window of applicability of a recycled plastic before an extra compounding step. MFI measurements are industrially available and can also be done in-line during processing, this might be an option for a stricter pellet quality control, but its applicability and desired ranges will have to be proven. Reduction of the amount of impurities will reduce issues with processing and enhance application of the recycled material.

\section{Enhancing applicability of existing recycled plastics}

A second route is to enhance the applicability of existing recycled plastics by improving processing and entering new application fields. The focus of this study was injection moulding applications for rPP, and extrusion (blow moulding) for rPE. The analysis methods were selected to reflect this. However, the properties of the recycled plastics make them potentially suited for a wider range of applications like for example automotive, household appliances, electronics, etc. In these applications different (and additional) properties are of interest like for example stiffness, gloss, long term stability, performance at extreme temperatures, compatibility with fillers, hardness, etc. In a follow-up project additional measurement methods for fundamental understanding such as properties of the surface vs bulk or related to specific applicability such as odour, gloss and food safety would need to be added to widen the scope of applicability.

As alternative, the recycled material can be made more suitable for a specific application by using additives, adjusting processing parameters and/or redesign the final product. This is called design-from-recycling and needs involvement of all stakeholders in the chain. Using additives or adjusting process parameters could for example enhance the flow of recycled rPP closer towards the high flow of virgin materials for injection moulding applications. In redesigning the product, for example the colour of recycled material can be taken into account as a given, or the use of complex shapes can be minimized such that a lower MFI product can be also injection moulded in the same shape.

\section{A new system based on advanced sorting technologies}

Post-consumer recycled plastics with a high polymeric purity are likely to be composed of several different grades of the same polymer, which limits the applicability. In order to identify and separate different grades, a new system based on advanced sorting technologies would be required. Ideas are 
for example to sort on different grades to avoid the "average" properties of recycled material or to use marking technology to enable food-safe applications for rPP and rPE.

Summarizing, there are multiple pathways to improve the circularity of PE and PP. Regardless which route(s) will be followed, active participation of all stakeholders is needed, including the EU and national governments to set out a policy in one or more of these directions. 


\section{Literature}

Alsewailem FD, Alrefaie JK. Effect of contaminants and processing regime on the mechanical properties and moldability of postconsumer polyethylene terephthalate bottles. Waste Manag. 2018;81:88-93

Bezati, F., D. Froelich, V. Massardier, and E. Maris. 2011. Addition of X-ray fluorescent tracers into polymers, new technology for automatic sorting of plastics: Proposal for selecting some relevant tracers. Resources, Conservation and Recycling 55 (12): 1214-1221. http://dx.doi.org/10.1016/j.resconrec.2011.05.014

Brandrup, J., Bittner, M., Michaeli, W. and Menges, G. (1996) Recycling and Recovery of Plastics. Carl Hanser Verlag, Munich and New York.

Brouwer MT, Alvarado Chacon F, Thoden van Velzen EU. Effect of recycled content and rPET quality on the properties of PET bottles, part III: modelling of repetitive recycling. Submitted to Packag Technol Sci. 2019. Article DOI: 10.1002/pts. 2489

Brouwer, M., Picuno, C., Thoden van Velzen, E.U., Kuchta, K.,De Meester, S., Ragaert, K. 2019. The impact of collection portfolio expansion on key performance indicators of the Dutch recycling system for Post-Consumer Plastic Packaging Waste, a comparison between 2014 and 2017, Waste Management 100, 112-121, DOI: 10.1016/j.wasman.2019.09.012.

Brouwer MT, Thoden van Velzen EU, Augustinus A, Soethoudt H, DeMeester S, Ragaert K. 2018. Predictive model for the Dutch post-consumer plastic packaging recycling system and implications for the circular economy Waste management 71,62-85. DOI: 10.1016/j.wasman.2017.10.034

Engelshoven van, Y., Wen, P., Bakker, M., Balkenende, R., Rem, P. An Innovative Route to Circular Rigid Plastics. Sustainability 2019, 11, 6824. doi:10.3390/su11226284

Holy Grail project report. See website: https://www.newplasticseconomy.org/assets/doc/HolyGrail.pdf

Luijsterburg B. and H. Goossens, Assessment of plastic packaging waste: Material origin, methods, properties. Resources Conservation and Recycling 85, 88-97 (2014).

http://dx.doi.org/10.1016/j.resconrec.2013.10.010

Luijsterburg, B.J., Jobse, P.S., Spoelstra, A.B., Goossens, J.G.P. Solid-state drawing of post-consumer isotactic poly(propylene): Effect of melt filtration and carbon black on structural and mechanical properties. Waste Management 2016, 54, 53-61. http://dx.doi.org/10.1016/j.wasman.2016.04.029

Kamleitner, F., Duscher, B., Koch, T., Knaus, S., Archodoulaki, VM. Long chain branching as an innovative up-cycling process of polypropylene post-consumer waste - Possibilities and limitations. Waste Management 68 (2017) 32-37. http://dx.doi.org/10.1016/j.wasman.2017.07.022

Masmoudi F, Fenouillot F, Mehri A, Jaziri M, Ammar E. Characterization and quality assessment of recycled post-consumption poly(ethylene terephthalate) (PET). Environ Sci Poll Res 2018; 25: 23307-23314. https://doi.org/10.1007/s11356-018-2390-7

Polymark website, http://www.polymark.org/

Popel C.P. 2019. Circular Economy along the entire value chain - Innovative applications from Extrusion and Injection Moulding. AMI Recycling Conference. Düsseldorf, 18-19.06.2019 
Prism initiative, see for instance website: http://www.recyclingpoint.info/plastics-the-fluorescentlabel-a-recycling-revolution/?lang=en

Ragaert, K., Delva, L., Geem van, K., 2017. Mechanical and chemical recycling of solid plastic waste. Waste Manage. 69, 24-58. https://doi.org/10.1016/j.wasman.2017.07.044

RB, 2019. From black to grey - all part of our commitment to going green.

https://www.rb.com/media/news/2019/august/from-black-to-grey-all-part-of-our-commitment-togoing-green/, visited on 12-11-2019

Snell H, Nassour A, Nelles M. Qualitative comparison of polyethylene terephthalate flakes from various collection systems in Germany. Waste Manage Res 2017; 35(2): 163-171, https://doi.org/10.1177/0734242X1668641

Thoden van Velzen, E.U., Brouwer, M.T., Huremovic, D. 2018. Sorting protocol for packaging wastes. WFBR report 1826, Wageningen UR Food \& Biobased Research. http://library.wur.nl/WebQuery/wurpubs/fulltext/451703

Thoden van Velzen EU, Jansen M, Brouwer MT, Feil A, Molenveld K, Pretz T, 2016 A. Efficiency of recycling post-consumer plastic packages. In: Proceedings of the 32th International Conference of the Polymer Processing Society 25-29 July, Lyon, AIP Conference Proceedings 1914, 170002 (2017), https://doi.org/10.1063/1.5016785

Thoden van Velzen EU, Brouwer MT, Molenveld K. Technical quality of rPET. Wageningen: Wageningen Food\&Biobased Research; 2016 B. 147p. http://edepot.wur.nl/392306

Vilaplana, F., Karlsson, S., 2008. Quality concepts for the improved use of recycled polymeric materials: a review. Macromol. Mater. Eng. 293 (4), 274-297. DOI: 10.1002/mame.200700393

Welle F. Twenty years of PET bottle to bottle recycling-An overview. Resour Conserv Recy 2011; 55 : 865-875. http://dx.doi.org/10.1016/j.resconrec.2011.04.009. 


\section{Appendix A}

In order to reach a high polymeric purity of the PE and PP washed milled goods that were used as a base sample for this research, all other materials were manually removed from the packages. Only bodies, caps and labels of the targeted material were used as part of the sample. The targeted and removed parts are listed in Table A.1 and Table A.2. The removed parts are distinguished between: caps, labels and removed packages or other items and parts with in-mould-labels or coatings (only for PP). Caps and labels of non-targeted materials were removed. Packages and other items were removed when it was impossible to remove the label completely, when the packaging was suspected to be made of a multi-layer material or when the package was contaminated with much product residue. All other objects with doubtful polymeric purity were removed as well. For PP specifically, also the packages with in-mould-labels or coatings were removed, as these labels and coating could be made of a different polymer than PP.

Table A.1 PP parts and removed parts from the PP flasks and PP other rigid packages.

\begin{tabular}{lcc} 
& PP flasks & PP rigid other \\
PP parts & $\mathbf{3 4} \pm \mathbf{6 \%}$ & $\mathbf{5 3} \pm \mathbf{6 \%}$ \\
\hline PP parts with IML/coating & $0.6 \pm 1.2 \%$ & $24 \pm 4 \%$ \\
\hline Non-PP caps & $3.0 \pm 1.3 \%$ & $0.6 \pm 0.5 \%$ \\
\hline Non-PP labels & $1.5 \pm 0.4 \%$ & $0.3 \pm 0.1 \%$ \\
\hline Removed packages and other items & $61 \pm 6 \%$ & $22 \pm 3 \%$ \\
\hline
\end{tabular}

Table A. 2 packages.

PE parts and removed parts from the PE bottles, PE flasks and PE other rigid

\begin{tabular}{lccc} 
& PE bottles & PE flasks & PE rigid other \\
PE parts & $\mathbf{3 9 \pm \mathbf { 4 } \%}$ & $\mathbf{6 1} \pm \mathbf{4 \%}$ & $\mathbf{5 5} \pm \mathbf{7 \%}$ \\
\hline Non-PE caps & $0.2 \pm 0.2 \%$ & $5.2 \pm 0.4 \%$ & $5.7 \pm 0.8 \%$ \\
\hline Non-PE labels & $0.3 \pm 0.1 \%$ & $2.0 \pm 0.5 \%$ & $0.6 \pm 0.5 \%$ \\
\hline Removed packages and other items & $61 \pm 4 \%$ & $32 \pm 5 \%$ & $39 \pm 8 \%$
\end{tabular}




\section{Appendix B}

\begin{tabular}{|c|c|c|c|c|c|c|c|c|c|c|c|c|c|c|c|c|}
\hline Description & $\%$ & MFI (pellets) & \begin{tabular}{|l} 
Spiral flow \\
(pellets)
\end{tabular} & $\begin{array}{l}\text { Charpy } \\
\text { Impact } \\
\text { (test } \\
\text { bars) }\end{array}$ & \begin{tabular}{|l}
$\begin{array}{l}\text { Density } \\
\text { (test } \\
\text { bars) }\end{array}$ \\
\end{tabular} & $\begin{array}{l}\text { Colour } \\
\text { (teat } \\
\text { bars) }\end{array}$ & \begin{tabular}{|l} 
DSC \\
(pellets)
\end{tabular} & $\begin{array}{l}\text { DMTA } \\
\text { (test } \\
\text { bars) }\end{array}$ & \begin{tabular}{|l|} 
FT-IR \\
(pellets)
\end{tabular} & \begin{tabular}{|l|} 
Viscosity \\
(com-pressed \\
pellets)
\end{tabular} & $\begin{array}{l}\text { SEM (test } \\
\text { bars) }\end{array}$ & $\begin{array}{l}\text { TGA } \\
\text { (pellets) }\end{array}$ & $\begin{array}{l}\text { FIIR (test } \\
\text { bars bulk } \\
\text { vs } \\
\text { surface) }\end{array}$ & Odour & Gloss & $\begin{array}{l}\text { Food } \\
\text { grade }\end{array}$ \\
\hline \multirow[t]{2}{*}{$\begin{array}{l}\text { Reference, } \\
100 \% \text { rPP }\end{array}$} & $0 \%$ & $\checkmark$ & $\checkmark$ & $\checkmark$ & $\checkmark$ & $\checkmark$ & $\checkmark$ & $\checkmark$ & $\checkmark$ & $\checkmark$ & $x$ & $x$ & $x$ & $x$ & $x$ & $x$ \\
\hline & $2 \%$ & $\checkmark$ & $\checkmark$ & $\checkmark$ & $\checkmark$ & $\checkmark$ & $\checkmark$ & $\checkmark$ & $\checkmark$ & $\checkmark$ & $x$ & $x$ & $\mathrm{x}$ & $\mathrm{x}$ & $\mathrm{x}$ & $\mathrm{x}$ \\
\hline \multirow[t]{2}{*}{ HDPE } & $5 \%$ & $\checkmark$ & $\checkmark$ & $\checkmark$ & $\checkmark$ & $\checkmark$ & $\checkmark$ & $V$ & $\checkmark$ & $\checkmark$ & $x$ & $x$ & $x$ & $x$ & $x$ & $x$ \\
\hline & $10 \%$ & $\checkmark$ & $\checkmark$ & $\checkmark$ & $\checkmark$ & $\checkmark$ & $\checkmark$ & $\checkmark$ & $\checkmark$ & $\checkmark$ & $x$ & $x$ & $x$ & $x$ & $x$ & $x$ \\
\hline LDPE & $2 \%$ & $\checkmark$ & $\checkmark$ & $\checkmark$ & $\checkmark$ & $\checkmark$ & $\checkmark$ & $\checkmark$ & $\checkmark$ & $\checkmark$ & $x$ & $x$ & $x$ & $\mathrm{x}$ & $x$ & $x$ \\
\hline PET & $0.5 \%$ & $\checkmark$ & $\checkmark$ & $\checkmark$ & $\checkmark$ & $\checkmark$ & $\checkmark$ & $\checkmark$ & $\checkmark$ & $\checkmark$ & $x$ & $x$ & $x$ & $x$ & $x$ & $x$ \\
\hline PS & $0.5 \%$ & $\checkmark$ & $\checkmark$ & $\checkmark$ & $\checkmark$ & $V$ & $\checkmark$ & $\checkmark$ & $\checkmark$ & $\checkmark$ & $x$ & $x$ & $x$ & $x$ & $x$ & $x$ \\
\hline PVC & $0.5 \%$ & $\checkmark$ & $\checkmark$ & $\checkmark$ & $\checkmark$ & $\checkmark$ & $\checkmark$ & $\checkmark$ & $\checkmark$ & $\checkmark$ & $x$ & $x$ & $x$ & $x$ & $x$ & $x$ \\
\hline PP film & $3.5 \%$ & $\checkmark$ & $\checkmark$ & $\checkmark$ & $\checkmark$ & $\checkmark$ & $\checkmark$ & $\checkmark$ & $\checkmark$ & $\checkmark$ & $x$ & $x$ & $x$ & $x$ & $x$ & $\mathrm{x}$ \\
\hline Aluminium & $0.5 \%$ & $V$ & $\checkmark$ & $\checkmark$ & $\checkmark$ & $\checkmark$ & $\checkmark$ & $\checkmark$ & $\checkmark$ & $\checkmark$ & $x$ & $x$ & $x$ & $x$ & $x$ & $x$ \\
\hline $\begin{array}{l}\text { In mould labels } \\
\text { (packages) }\end{array}$ & $50 \%$ & $\checkmark$ & $\checkmark$ & $\checkmark$ & $\checkmark$ & $\checkmark$ & $\checkmark$ & $\checkmark$ & $\checkmark$ & $\checkmark$ & $x$ & $x$ & $x$ & $x$ & $x$ & $x$ \\
\hline In mould labels & $5 \%$ & $\checkmark$ & $\checkmark$ & $\checkmark$ & $\checkmark$ & $\checkmark$ & $\checkmark$ & $\checkmark$ & $\checkmark$ & $\checkmark$ & $x$ & $x$ & $x$ & $x$ & $x$ & $x$ \\
\hline
\end{tabular}

Figure B.1 rPP matrix indicating the sample variations (rows) vs the analysis method (columns). A " $V$ " indicates performed tests and " $X$ " indicates interesting tests not performed within this project

\begin{tabular}{|c|c|c|c|c|c|c|c|c|c|c|c|c|c|c|c|}
\hline Description & $\%$ & $\begin{array}{l}\text { MFI } \\
\text { (pellets) }\end{array}$ & $\begin{array}{l}\text { Viscosity } \\
\text { (com- } \\
\text { pressed } \\
\text { moulded } \\
\text { samples) }\end{array}$ & $\begin{array}{l}\text { Charpy } \\
\text { impact } \\
\text { (test } \\
\text { bars) } \\
\end{array}$ & $\begin{array}{l}\text { Falling } \\
\text { dart } \\
\text { (extruded } \\
\text { sheet) }\end{array}$ & $\begin{array}{l}\text { Tensile } \\
\text { strength } \\
\text { (extruded } \\
\text { sheet) }\end{array}$ & \begin{tabular}{|l} 
Density \\
(test \\
bars)
\end{tabular} & \begin{tabular}{|l} 
Colour \\
(test \\
bars)
\end{tabular} & $\begin{array}{l}\text { DsC + } \\
\text { crystallisa } \\
\text { tion } \\
\text { (pellets) }\end{array}$ & \begin{tabular}{|} 
FT-IR \\
(pellets)
\end{tabular} \mid & \begin{tabular}{|l} 
SEM \\
(sheets)
\end{tabular} & $\begin{array}{l}\text { TGA } \\
\text { (pellets) }\end{array}$ & $\begin{array}{l}\begin{array}{l}\text { FIIR } \\
\text { bulk / } \\
\text { surface } \\
\text { (pellets) }\end{array} \\
\end{array}$ & Odour & $\begin{array}{l}\text { Food } \\
\text { grade }\end{array}$ \\
\hline \multirow[t]{2}{*}{$\begin{array}{l}\text { Reference, } \\
100 \% \text { rPE }\end{array}$} & $0 \%$ & $\checkmark$ & $\checkmark$ & $\checkmark$ & $\checkmark$ & $\checkmark$ & $\checkmark$ & $\checkmark$ & $V$ & $V$ & $x$ & $x$ & $x$ & $\mathrm{x}$ & $x$ \\
\hline & $2 \%$ & $\checkmark$ & $V$ & $V$ & $V$ & $\checkmark$ & $\checkmark$ & $V$ & $V$ & $\checkmark$ & $x$ & $x$ & $x$ & $x$ & $x$ \\
\hline \multirow[t]{2}{*}{ PP } & $5 \%$ & $\checkmark$ & $V$ & $V$ & $V$ & $V$ & $\checkmark$ & $V$ & $V$ & $V$ & $x$ & $x$ & $x$ & $x$ & $x$ \\
\hline & $10 \%$ & $\checkmark$ & $V$ & $V$ & $V$ & $V$ & $V$ & $V$ & $V$ & $V$ & $x$ & $x$ & $x$ & $x$ & $x$ \\
\hline \multirow{2}{*}{ LDPE } & $2 \%$ & $V$ & $V$ & $V$ & $V$ & $V$ & $V$ & $V$ & $V$ & $V$ & $x$ & $\mathrm{x}$ & $x$ & $\mathrm{x}$ & $x$ \\
\hline & $5 \%$ & $V$ & $V$ & $\checkmark$ & $\checkmark$ & $\checkmark$ & $V$ & $V$ & $\checkmark$ & $\checkmark$ & $x$ & $x$ & $x$ & $x$ & $x$ \\
\hline PET & $0.5 \%$ & $V$ & $\checkmark$ & $\checkmark$ & $\checkmark$ & $\checkmark$ & $V$ & $\checkmark$ & $\checkmark$ & $\checkmark$ & $x$ & $x$ & $x$ & $x$ & $x$ \\
\hline PS & $0.5 \%$ & $\checkmark$ & $\checkmark$ & $\checkmark$ & $V$ & $\checkmark$ & $V$ & $V$ & $\checkmark$ & $V$ & $x$ & $x$ & $x$ & $x$ & $x$ \\
\hline PVC & $0.5 \%$ & $V$ & $V$ & $\checkmark$ & $V$ & $\checkmark$ & $V$ & $\checkmark$ & $V$ & $V$ & $x$ & $x$ & $x$ & $x$ & $x$ \\
\hline
\end{tabular}

Figure B.2 rPE matrix indicating the sample variations (rows) vs the analysis method (columns). A " $V$ " indicates performed tests and " $X$ " indicates interesting tests not performed within this project 


\section{Appendix C}

\section{Impurities found on melt filters}

\section{Table C.1 Photos of melt filters from extrusion of rPP samples.}

\begin{tabular}{|c|c|}
\hline Composition & $\begin{array}{l}\text { Particles on melt } \\
\text { filter }\end{array}$ \\
\hline 100rPP & $\begin{array}{l}\text { Aluminium, black, } \\
\text { yellow/green particles }\end{array}$ \\
\hline 2rHDPE & $\begin{array}{l}\text { Aluminium, black } \\
\text { small particles, yellow } \\
\text { and big white particles }\end{array}$ \\
\hline 5rHDPE & More white particles \\
\hline 10rHDPE & $\begin{array}{l}\text { Still more white } \\
\text { particles }\end{array}$ \\
\hline
\end{tabular}




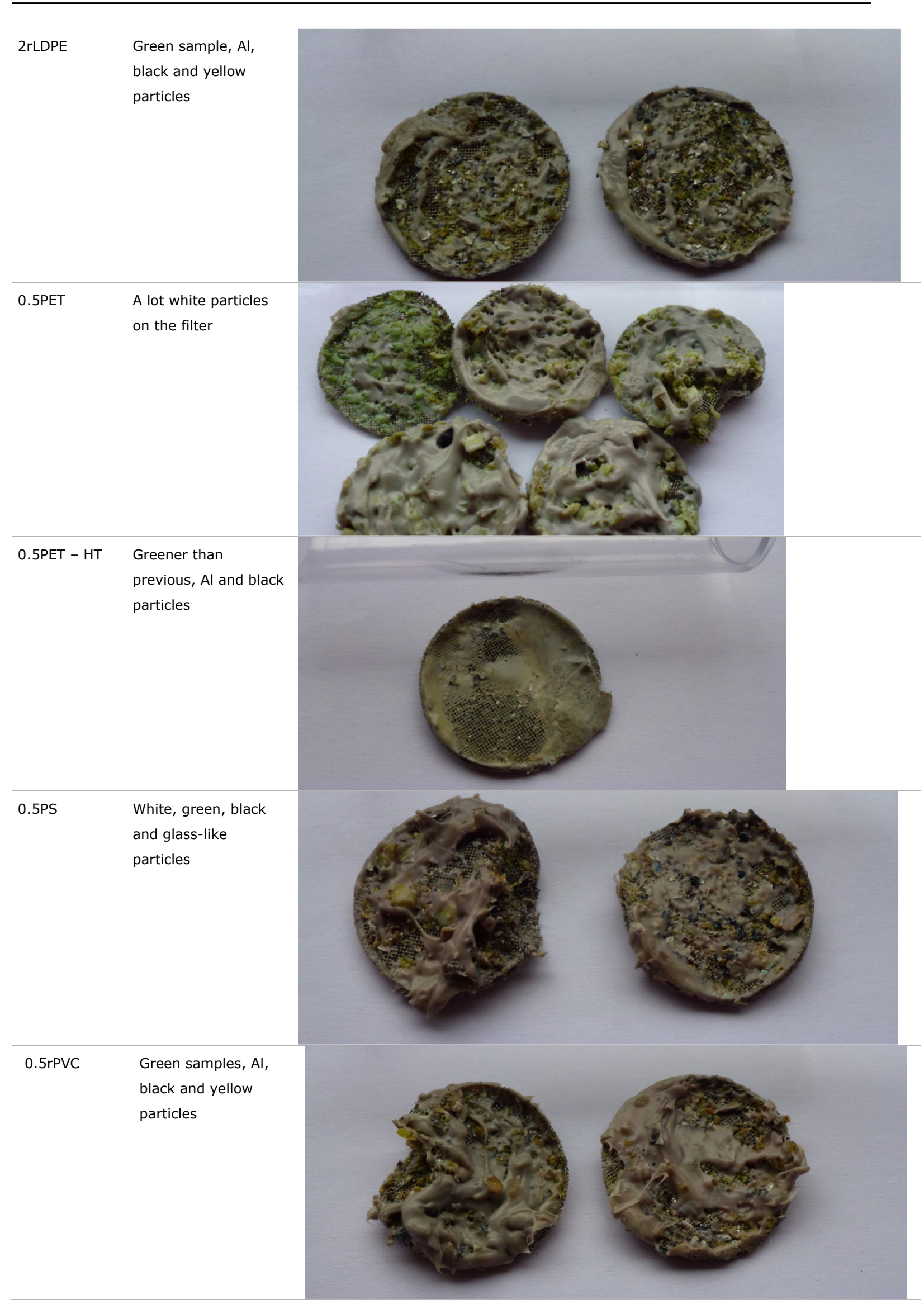




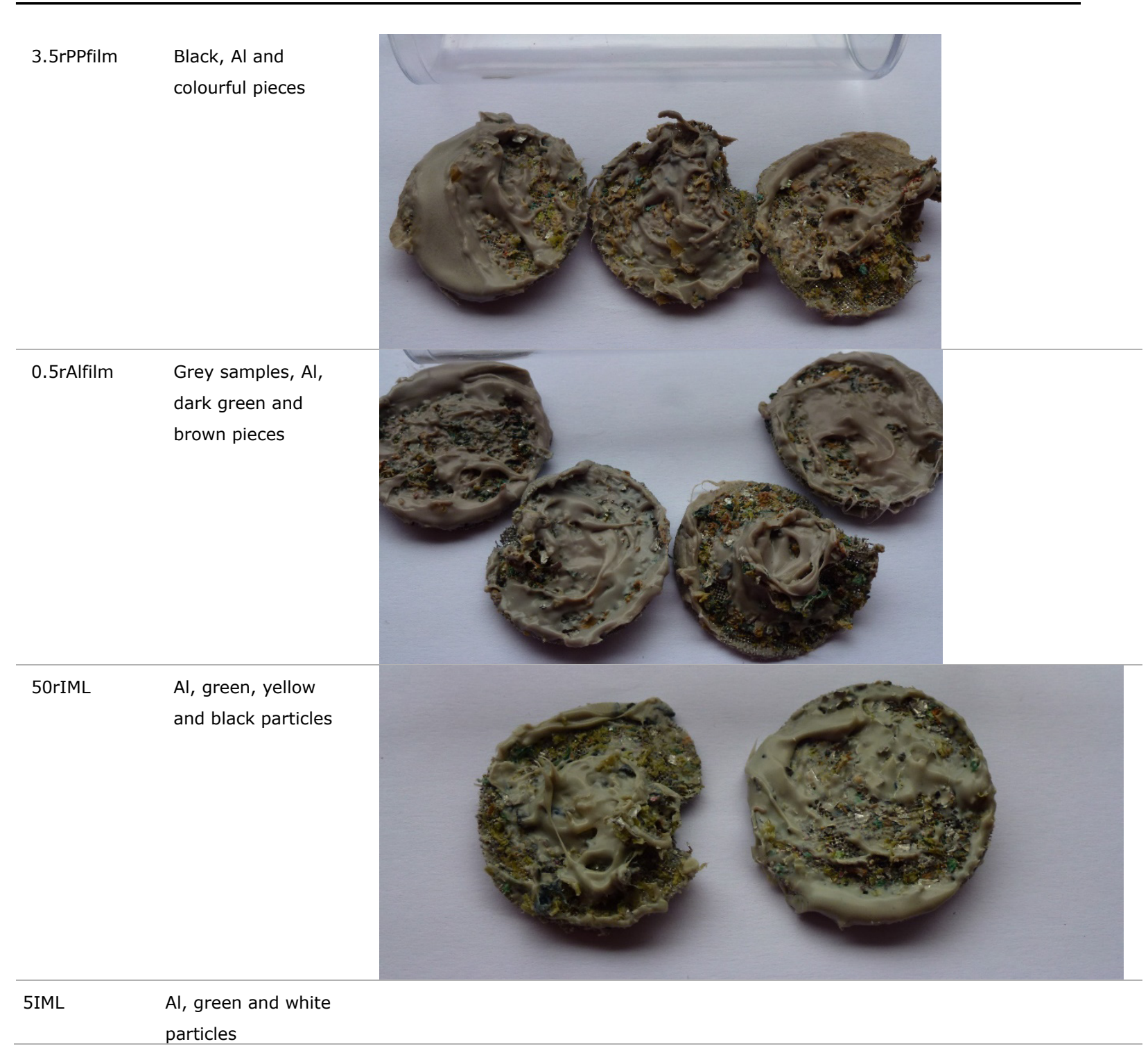




\section{Table C.2}

FTIR spectra of particles found on melt filters from extrusion of rPP samples.

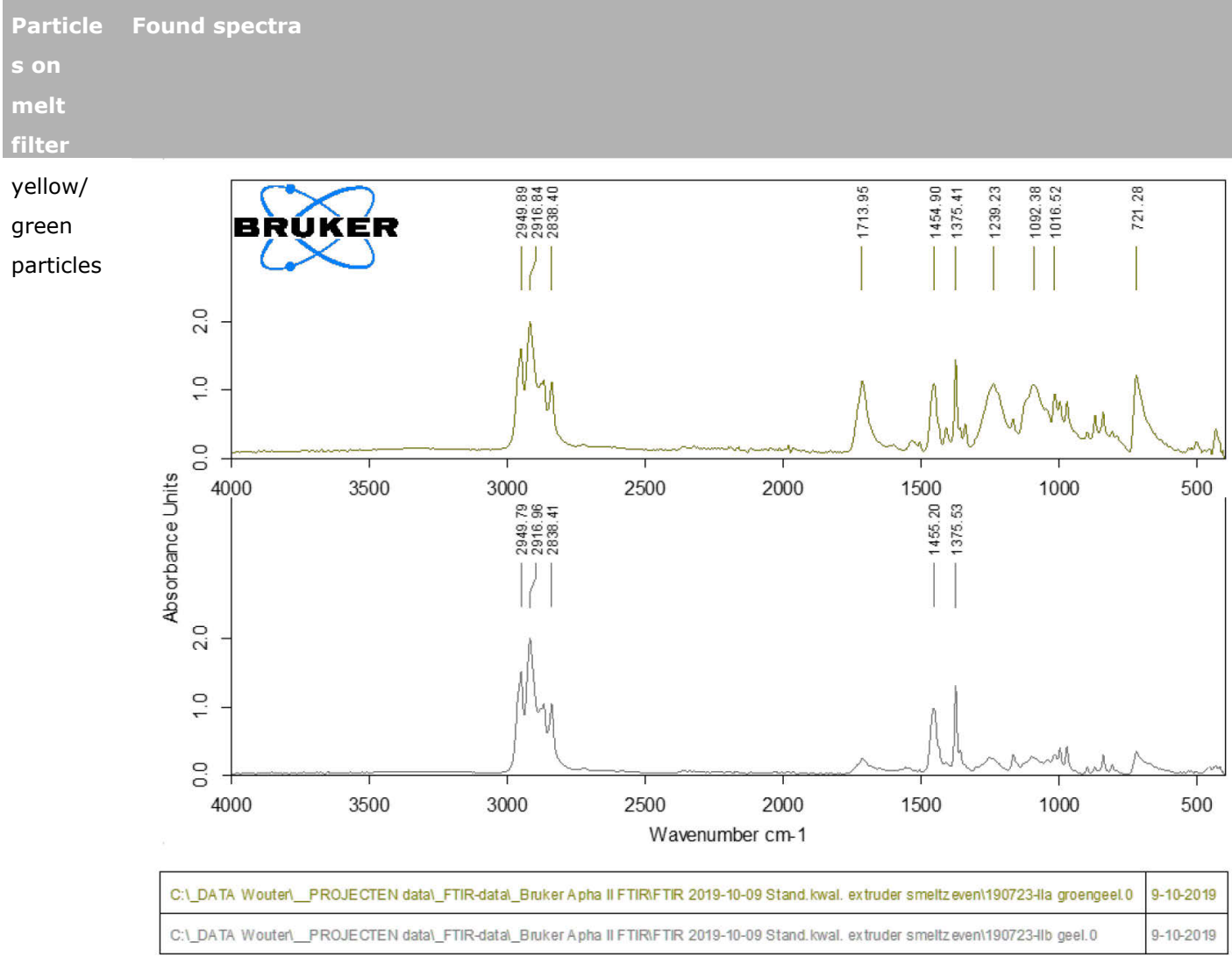

Page 1/1

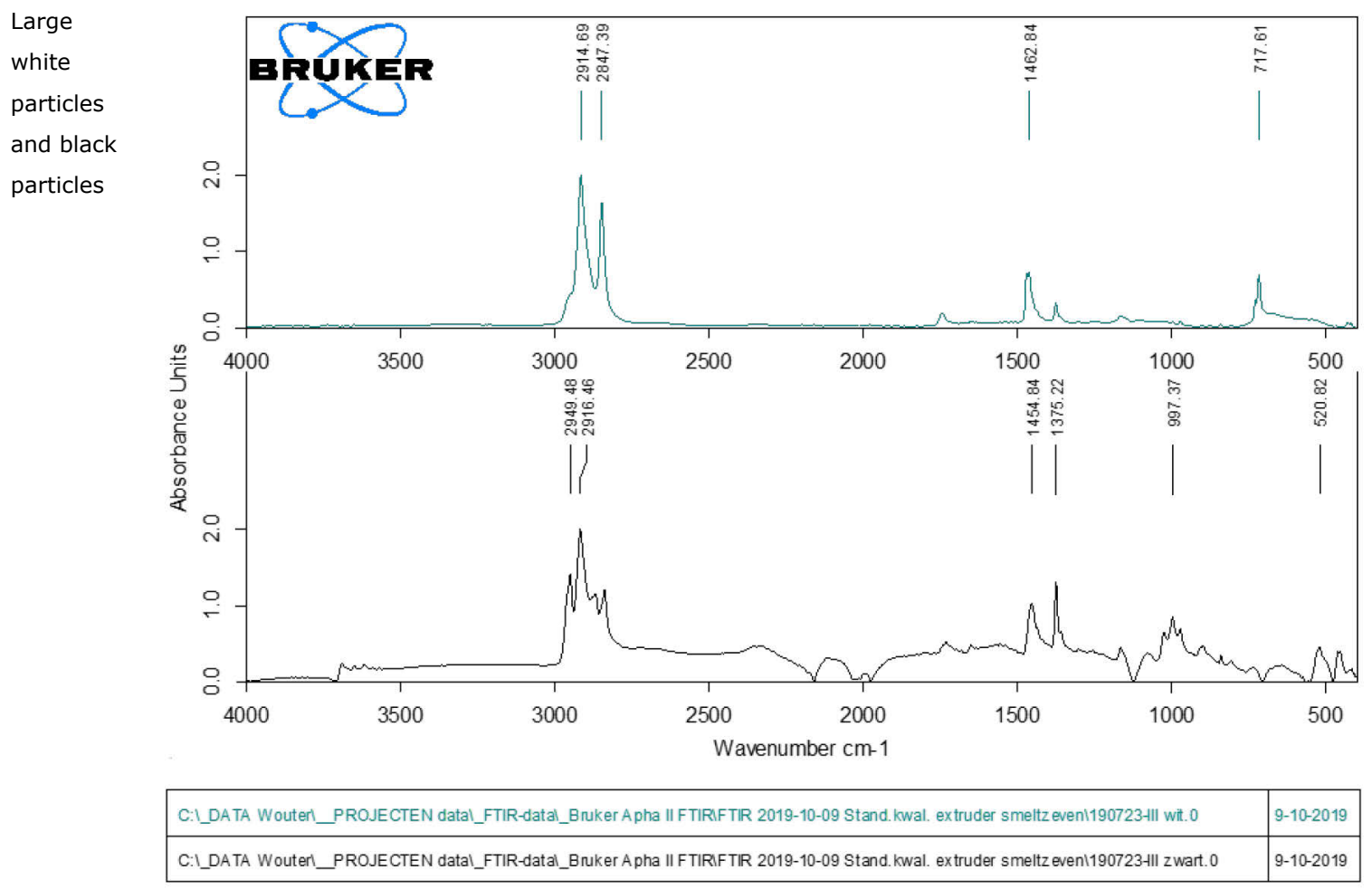

Page 1/1 


\section{Table C.3 Photos of particles found in rPE samples.}

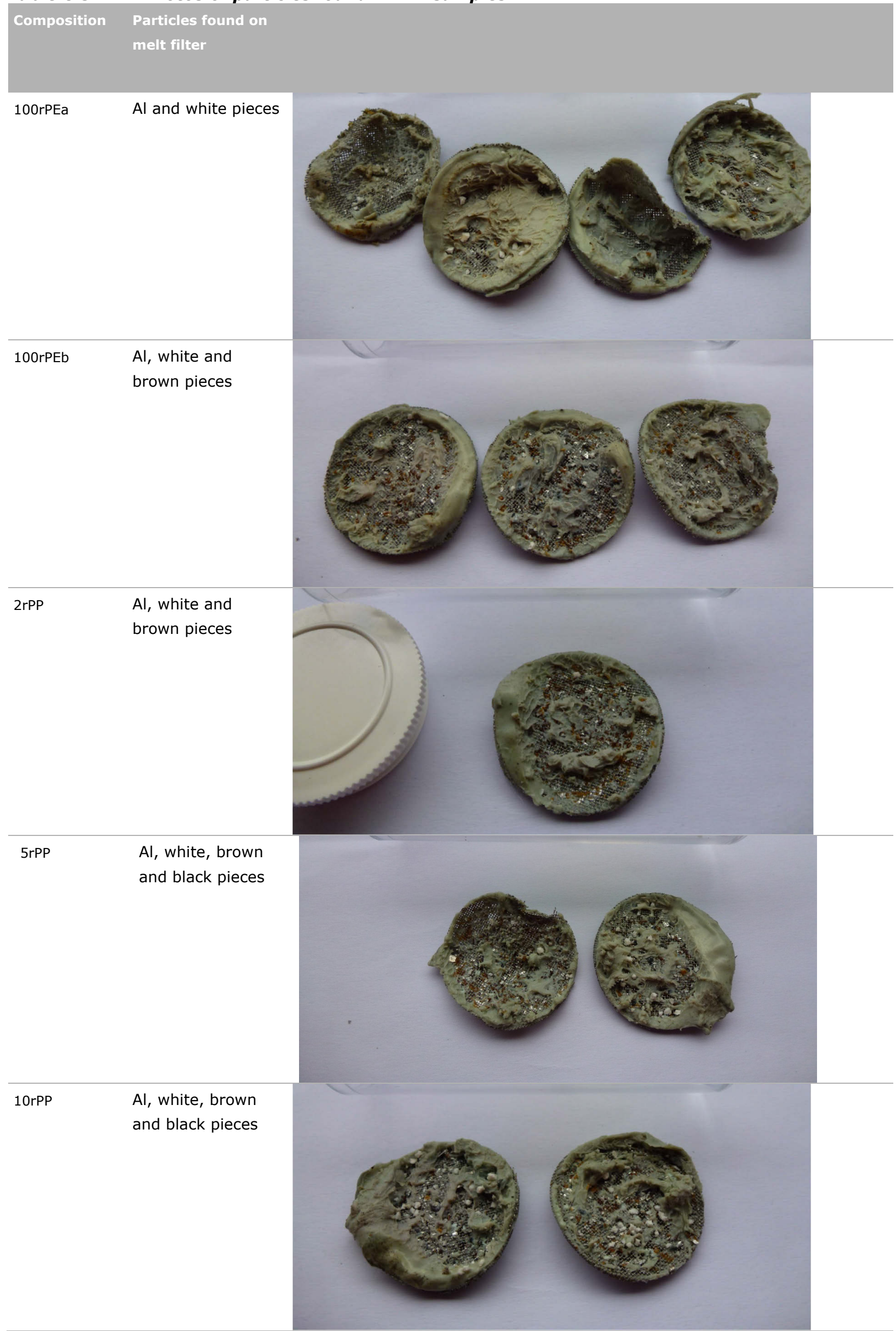




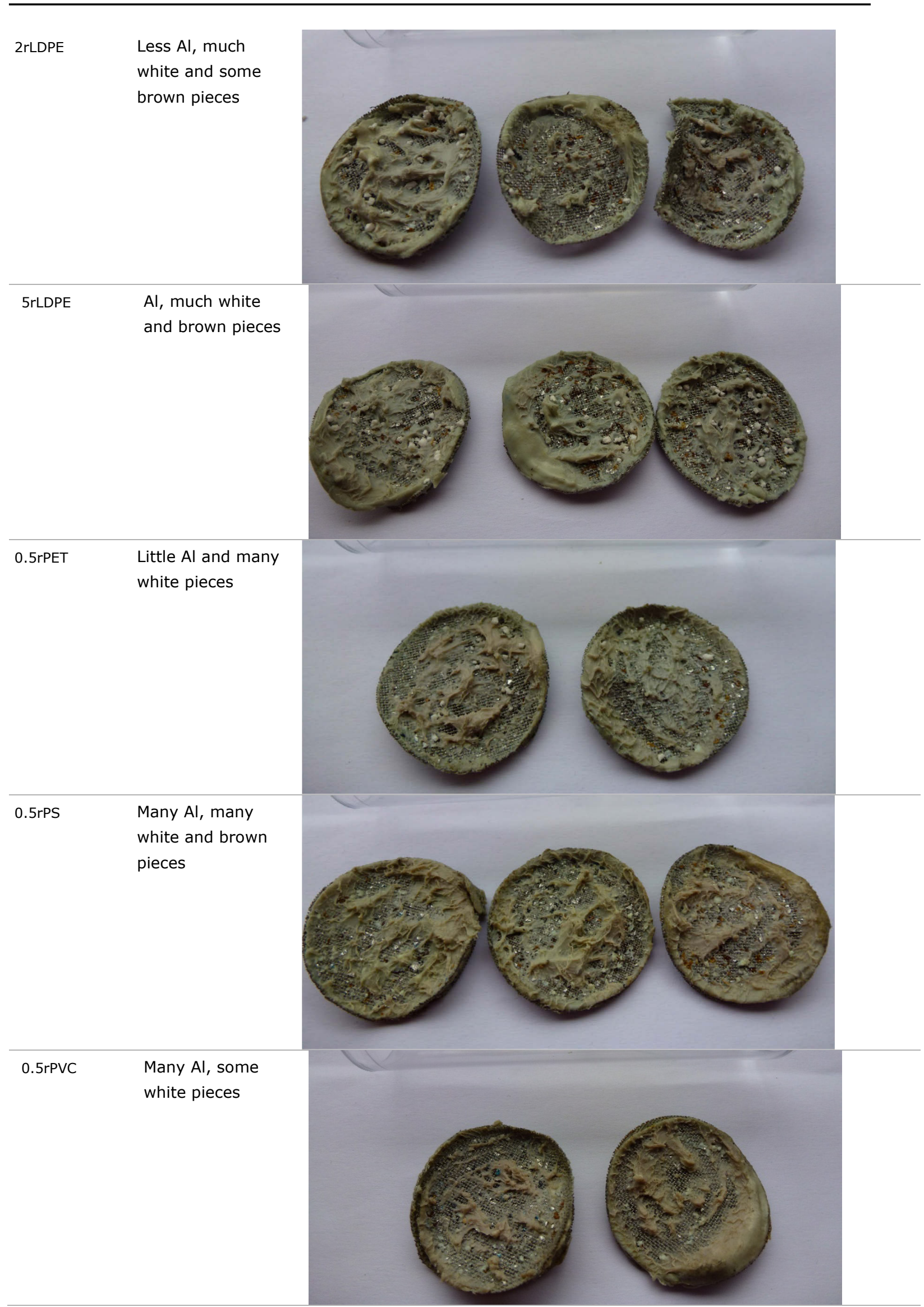


Table C. 4 FTIR spectra of particles found on melt filters from extrusion of rPE samples.

Particles Found spectra

on melt

filter

Referenc

e PE

spectra

and

White

rubbery

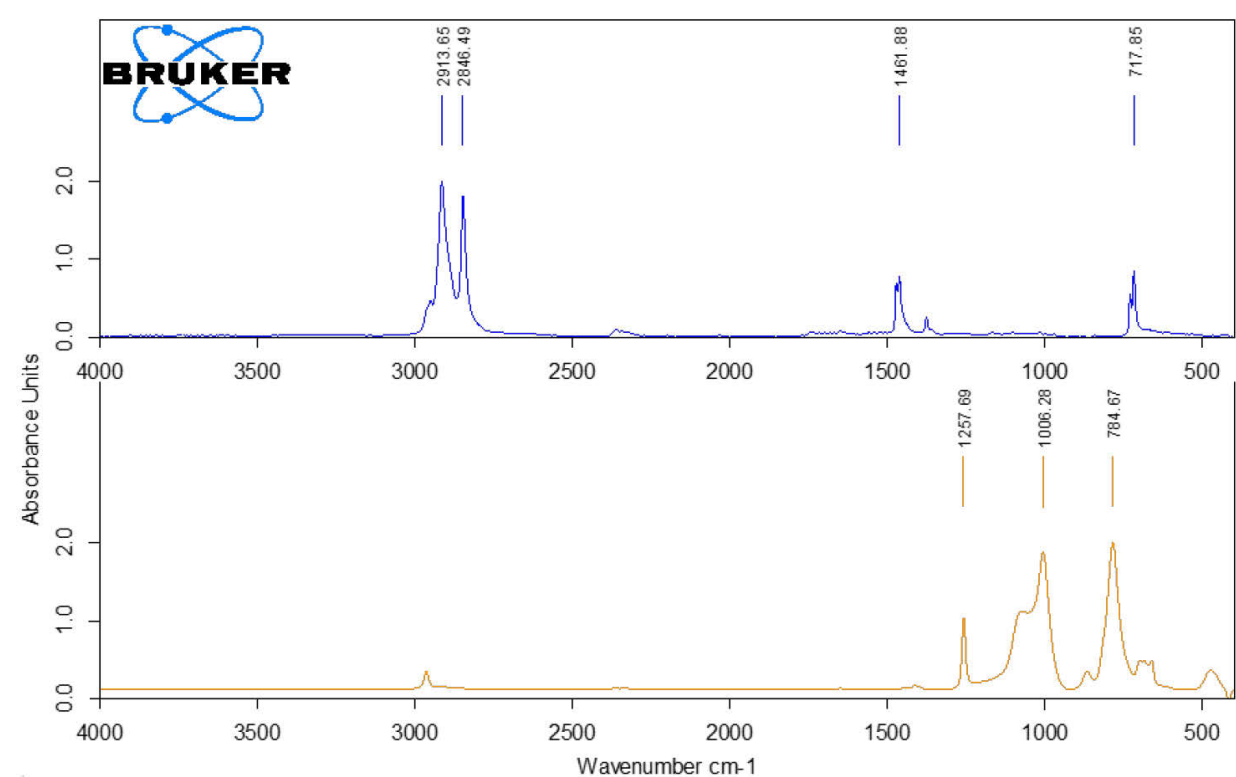

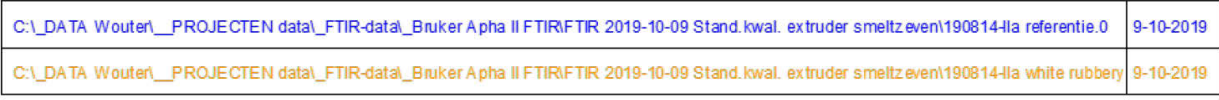

Page 1/1

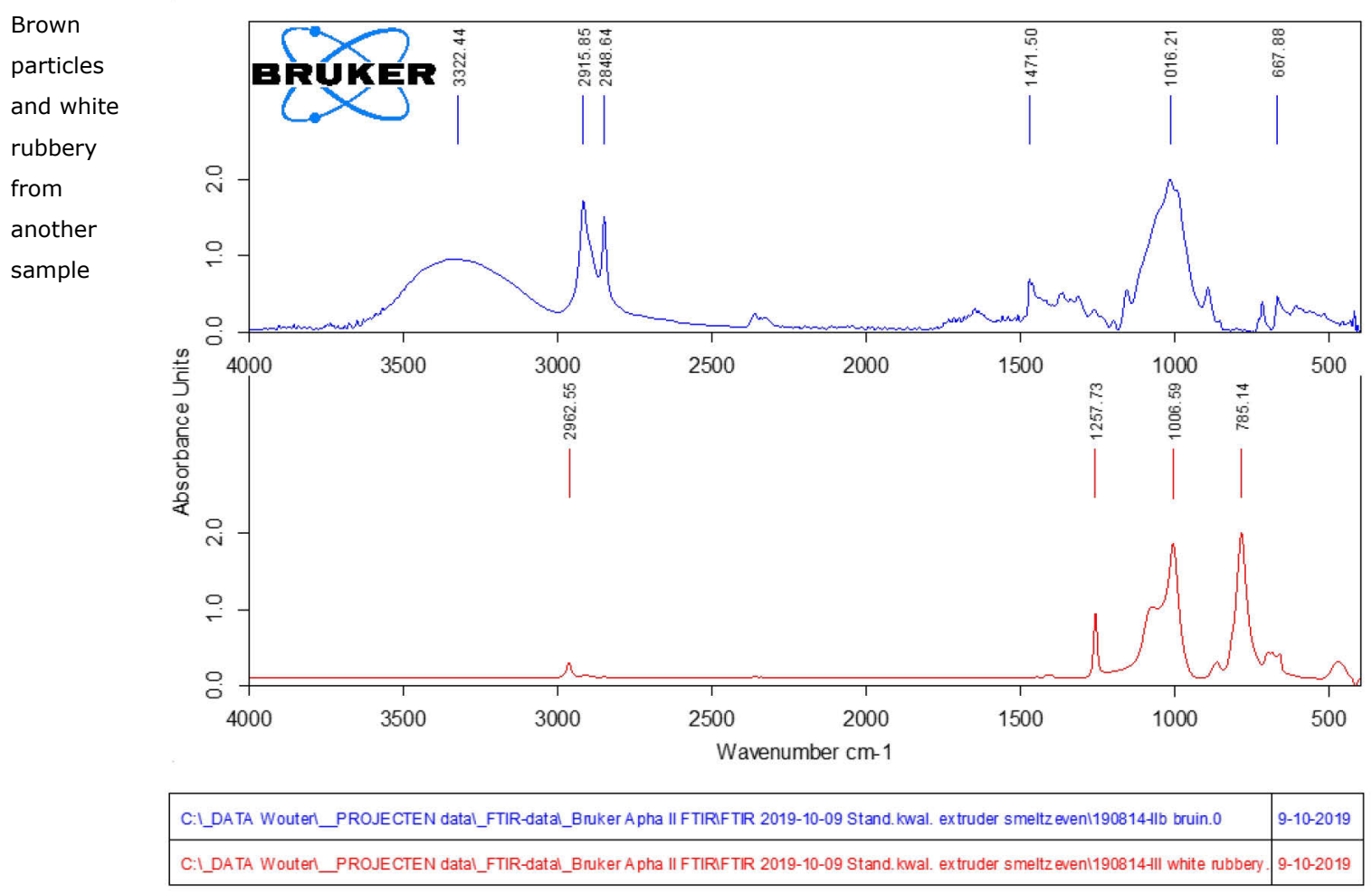

Page 1/1 


\section{Appendix D}

\section{Complementary measuring data}

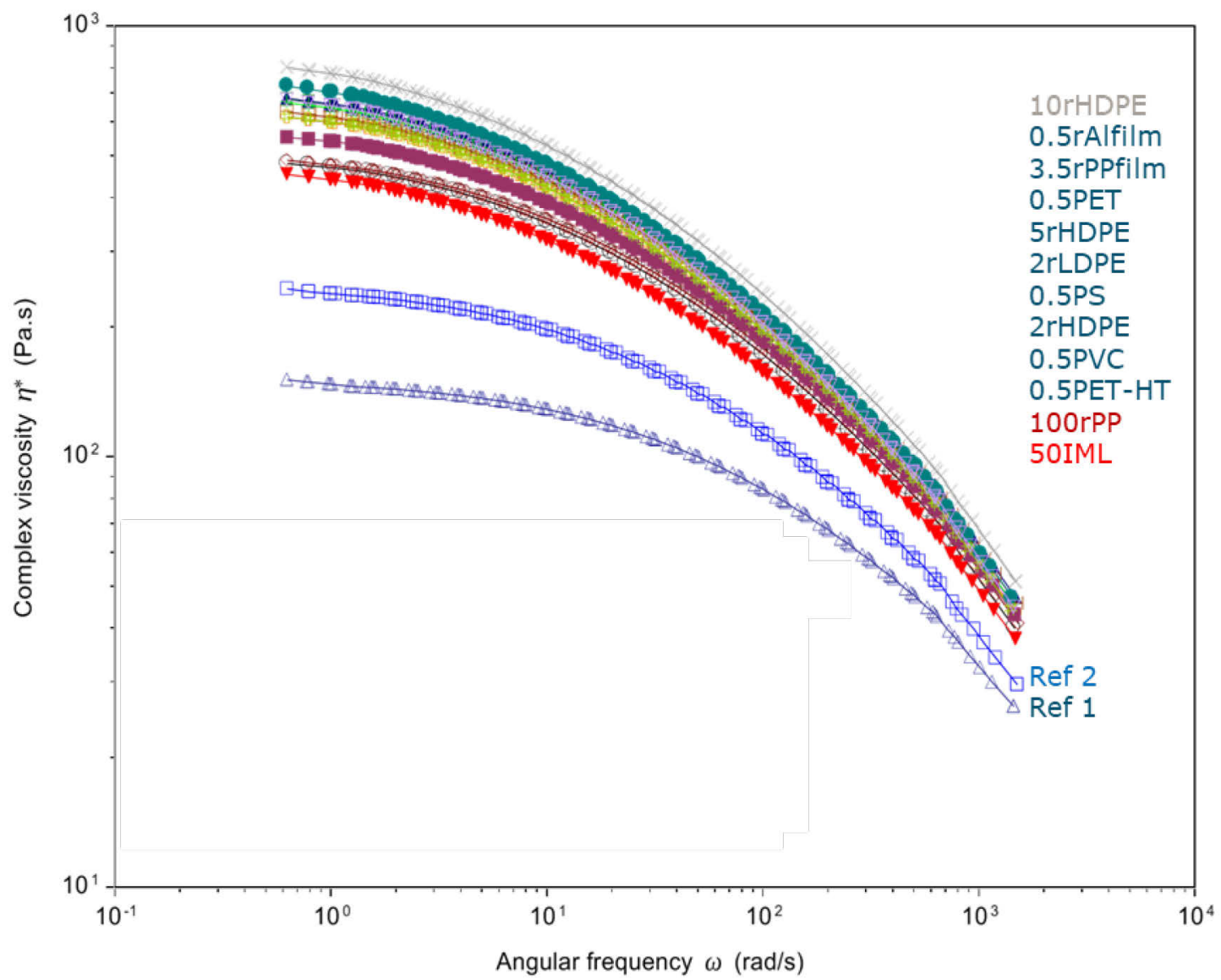

Figure D.1 Complex viscosity master curves of the prepared rPP samples and the two references. Data shown at $230^{\circ} \mathrm{C}$ 


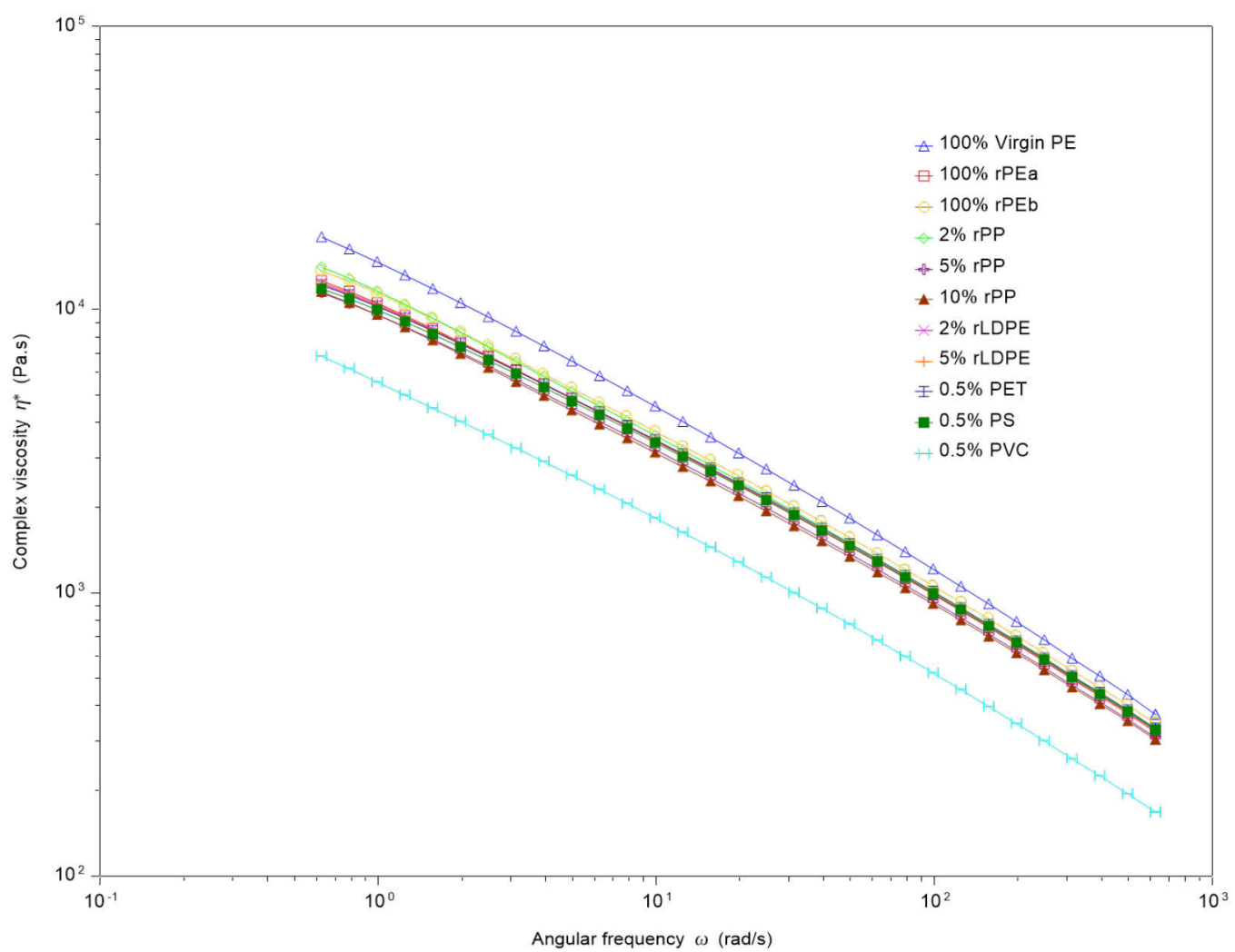

Figure D. 2 Complex viscosity curves of the prepared rPE samples and the reference at $250^{\circ} \mathrm{C}$

Table D.1 Unnotched impact results for rPP samples (DNB=do not break, impact $>99 \mathrm{~kJ} / \mathrm{m2}$ ).

\begin{tabular}{|c|c|c|c|c|}
\hline Sample code & $\begin{array}{l}\text { Unnotched } \\
\text { Avg. impact } \\
\text { strength }\end{array}$ & & & $\begin{array}{l}\text { Number of } \\
\text { samples that } \\
\text { DNB out of } 10 \\
\text { tested samples }\end{array}$ \\
\hline Ref 1 & 77 & \pm & 21 & \\
\hline Ref 2 & DNB & \pm & - & 10 \\
\hline 100rPP & 63 & \pm & 11 & \\
\hline 100rPP & 76 & \pm & 13 & \\
\hline 2rHDPE & 80 & \pm & 17 & 1 \\
\hline 5rHDPE & 83 & \pm & 24 & 5 \\
\hline 10rHDPE & 80 & \pm & 19 & 5 \\
\hline 2rLDPE & 85 & \pm & 15 & 3 \\
\hline 0.5PET & 74 & \pm & 7 & \\
\hline 0.5PET - HT & 84 & \pm & 17 & \\
\hline $0.5 P S$ & 72 & \pm & 12 & \\
\hline $0.5 r P V C$ & 74 & \pm & 16 & \\
\hline 3.5rPPfilm & 71 & \pm & 11 & \\
\hline 0.5 rAlfilm & 82 & \pm & 11 & \\
\hline 50rIML & 63.0 & \pm & 0.1 & \\
\hline 5rIML & 52.8 & \pm & 1.5 & \\
\hline
\end{tabular}


Table D.2 Measured colour of the different virgin materials and the produced rPP samples.

\begin{tabular}{|c|c|c|c|c|c|c|c|c|c|c|}
\hline Sample code & L* & & & a* & & & b* & & & $\Delta E$ \\
\hline Ref 1 & 76.2 & \pm & 1.6 & -0.3 & \pm & 0.1 & -1.2 & \pm & 0.1 & \\
\hline Ref 2 & 70.2 & \pm & 0.5 & 0.6 & \pm & 0.0 & 5.4 & \pm & 0.2 & \\
\hline 100rPP & 58.1 & \pm & 0.1 & 1.5 & \pm & 0.1 & 3.5 & \pm & 0.1 & \\
\hline 100rPP & 59.3 & \pm & 0.2 & 0.6 & \pm & 0.1 & 3.8 & \pm & 0.2 & \\
\hline 2rHDPE & 58.4 & \pm & 0.1 & 1.1 & \pm & 0.1 & 3.8 & \pm & 0.1 & 0.1 \\
\hline 5rHDPE & 58.6 & \pm & 0.4 & 1.2 & \pm & 0.1 & 3.7 & \pm & 0.2 & 0.0 \\
\hline 10rHDPE & 59.8 & \pm & 0.1 & 1.1 & \pm & 0.1 & 4.5 & \pm & 0.1 & 1.0 \\
\hline 2rLDPE & 59.8 & \pm & 0.1 & -0.7 & \pm & 0.1 & 4.8 & \pm & 0.2 & 2.7 \\
\hline 0.5 PET & 59.4 & \pm & 0.1 & -1.5 & \pm & 0.0 & 4.6 & \pm & 0.1 & 3.7 \\
\hline 0.5PET - HT & 58.8 & \pm & 0.2 & -2.3 & \pm & 0.0 & 3.3 & \pm & 0.2 & 5.6 \\
\hline $0.5 \mathrm{PS}$ & 58.4 & \pm & 0.0 & 1.6 & \pm & 0.1 & 4.0 & \pm & 0.1 & 0.3 \\
\hline $0.5 r P V C$ & 58.9 & \pm & 0.1 & -0.4 & \pm & 0.1 & 5.2 & \pm & 0.1 & 2.1 \\
\hline 3.5rPPfilm & 56.7 & \pm & 0.1 & 0.5 & \pm & 0.1 & 4.4 & \pm & 0.2 & 2.5 \\
\hline 0.5 rAlfilm & 57.6 & \pm & 0.1 & 0.8 & \pm & 0.1 & 4.8 & \pm & 0.1 & 1.4 \\
\hline 50rIML & 63.0 & \pm & 0.1 & -2.1 & \pm & 0.1 & 6.2 & \pm & 0.2 & 17.6 \\
\hline 5rIML & 52.8 & \pm & 1.5 & 1.1 & \pm & 0.2 & 6.8 & \pm & 0.2 & 22.5 \\
\hline
\end{tabular}




\section{Appendix E}

Datasheets of used reference materials

Polypropylene PPR 10232

\section{TOTAL}

Refining \& Chemicals

Polymers
Technical data sheet

Polypropylene - Random Copolymer

\section{Description}

Polypropylene PPR 10232 is a nucleated and antistatic random copolymer polypropylene with a Melt Flow Index of $40 \mathrm{~g} / 10 \mathrm{~min}$ for the injection moulding of articles with high transparency and excellent surface appearance.

Polypropylene PPR 10232 has an excellent food compatibility thanks to its low odour, making it especially suitable for the production of food packaging and houseware products.

We hereby confirm that we do not use peroxide in the manufacturing of the above-mentioned Product.

\section{Characteristics}

\begin{tabular}{|c|c|c|c|}
\hline & Method & Unit & $\begin{array}{c}\text { Typical } \\
\text { Value }\end{array}$ \\
\hline \multicolumn{4}{|l|}{ Rheological properties } \\
\hline Melt Flow Index $230^{\circ} \mathrm{C} / 2.16 \mathrm{kq}$ & ISO 1133 & $\mathrm{a} / 10 \mathrm{~min}$ & 40 \\
\hline \multicolumn{4}{|l|}{ Mechanical properties } \\
\hline Tensile Strength at Yield & ISO $527-2$ & $\mathrm{MPa}$ & 28 \\
\hline Elongation at Yield & ISO $527-2$ & $\%$ & 10 \\
\hline Tensile modulus & ISO $527-2$ & $\mathrm{MPa}$ & 1200 \\
\hline Flexural modulus & ISO 178 & $\mathrm{MPa}$ & 1150 \\
\hline Izod Impact Strength (notched) at $23^{\circ} \mathrm{C}$ & ISO 180 & $\mathrm{~kJ} / \mathrm{m}^{2}$ & 5 \\
\hline Charpy Impact Strength (notched) at $23^{\circ} \mathrm{C}$ & ISO 179 & $\mathrm{~kJ} / \mathrm{m}^{2}$ & 6 \\
\hline Hardness Rockwell - R-scale & ISO $2039-2$ & & 84 \\
\hline \multicolumn{4}{|l|}{ Thermal properties } \\
\hline Melting Point & ISO 3146 & ${ }^{\circ} \mathrm{C}$ & 147 \\
\hline Vicat Softening Point & ISO 306 & ${ }^{\circ} \mathrm{C}$ & \\
\hline $50 \mathrm{~N}-50^{\circ} \mathrm{C}$ per hour & & & 67 \\
\hline $10 \mathrm{~N}-50^{\circ} \mathrm{C}$ per hour & & & 130 \\
\hline \multicolumn{4}{|l|}{ Other physical properties } \\
\hline Density & ISO 1183 & $\mathrm{~g} / \mathrm{cm}^{3}$ & 0.902 \\
\hline Bulk Density & ISO 1183 & $\mathrm{~g} / \mathrm{cm}^{3}$ & 0.525 \\
\hline
\end{tabular}

\section{Handling and storage}

Please refer to the safety data sheet (SDS) for handling and storage information. It is advisable to convert the product within one year after delivery provided storage conditions are used as given in the SDS of our product. SDS may be obtained from the website: http://www.totalrefiningchemicals,com An Injection Moulding troubleshooting guide is available upon request.

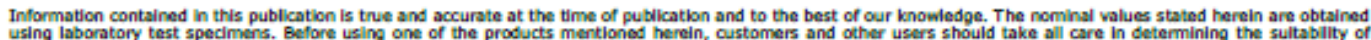
The Companies within Total petrochemicals do not accept any llability whatsoever arising from the use of this information of the use, application or processing of any product described herein. No information contained in this publication can be considered as a suggestion to infringe patents. The Companies disdain any llability that may be clainned for infringement or alleged infiningennent of patents.

TOTAL RESEARCH \& TECHNOLOGY FELUY Zone industrelle $\mathrm{C}$ B-7181 Fetrign
Belglum

\section{Rev : August 13}

Page $1 / 1$ website : www.totalrefiningchemicals.com 


\section{DESCRIPTION}

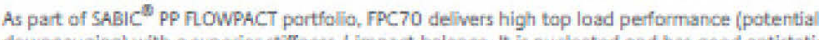

downgauging) with a superior stiffness / impact balance. it is nucleated and has good antistatic performance

with easy demoulding. This grade has good flow behavior, and it is typically used by our customer for hightspeed injection

moulding process, potentially enabling very cost efficient processing an the basis of easy mould filling and

very short cycle times.

Applications:

SABC ${ }^{3}$ PP FPC70 is typically used in rigid packaging applicatians for both food and non-foot industries.

This includes packaging for yellow fats, cheese spreads, dairy, frozen, chilled and ambient food, household

chemicals and paints among others,

It can be also used in severa appications in the caps \& closures as well in housewares.

The grade has excellentit heat defiection temperature making it may particularly be used for hot fill applications

Health, Safety and food Contact regulations

Material Safety Data Sheets (MSDS) and Product Safety declarations are awailable on our Internet site

Hitp: //WWw.SABIC.com

This product is not intended for and must not be used in any pharmaceutical/medical applications.

TYPICAL PROPERTY VALUES

\begin{tabular}{|c|c|c|c|}
\hline PROPERTIES & TYPICAL VALUES & UNITS & TEST METHODS \\
\hline \multicolumn{4}{|l|}{ POLYMER PROPERTES } \\
\hline \multicolumn{4}{|l|}{ Met: Flow Rate } \\
\hline at $230^{\circ} \mathrm{C}$ and $216 \mathrm{bg}$ & 70 & $d g / m i n$ & 1501133 \\
\hline Dendity & 905 & mim & ASTM D1505 \\
\hline \multicolumn{4}{|l|}{ FOคMUUATION } \\
\hline Anti static agent & $\square$ & & \\
\hline Nucleating agent & 区 & & \\
\hline \multicolumn{4}{|c|}{ MECHANICAL FEOPERTIES } \\
\hline \multicolumn{4}{|l|}{ Tensile test } \\
\hline stres at yiedd ${ }^{(t)}$ & 28 & Mha & $150527.21 \mathrm{~A}$ \\
\hline strain at pieid & 4 & $x$ & $15052721 \mathrm{~A}$ \\
\hline tersile moduas $^{(2)}$ & 1700 & MFa & $150527.21 \mathrm{~A}$ \\
\hline \multicolumn{4}{|l|}{ lzod impact notched } \\
\hline at $230 \mathrm{C}$ & 6 & $\mathrm{~b} / \mathrm{m}^{2}$ & 150 180/ $1 \mathrm{~A}$ \\
\hline at $0{ }^{\circ} \mathrm{C}$ & 4 & bj $/ m^{2}$ & $150180 / 1 \mathrm{~A}$ \\
\hline at $20 \% \mathrm{C}$ & 3 & bj $/ m^{2}$ & $150180 / 1 \mathrm{~A}$ \\
\hline \multicolumn{4}{|c|}{ Charpy Impact Strength Notched } \\
\hline at 23 \& & 7 & $\mathrm{~b} / \mathrm{m}^{2}$ & ISO 179/1eA \\
\hline at $0{ }^{\circ} \mathrm{C}$ & 5 & $\mathrm{w} \mid \mathrm{m}^{2}$ & $150179 / 1 \mathrm{ch}$ \\
\hline at $20 \% \mathrm{C}$ & 3 & $\mathrm{~b} / \mathrm{m}^{2}$ & $150179 / 1 \mathrm{eA}$ \\
\hline \multicolumn{4}{|l|}{ THERUAL PROPERTIES } \\
\hline \multicolumn{4}{|c|}{ Heat deflection temperature ${ }^{(p)}$} \\
\hline at $0.45 \mathrm{MPa}$ (HDT/B) & 100 & ${ }^{2} \mathrm{C}$ & 19075 \\
\hline at $1.80 \mathrm{MPa}(\mathrm{HDT} / \mathrm{A})$ & 60 & ${ }^{4} \mathrm{C}$ & 15075 \\
\hline
\end{tabular}

Q 2019 Copyright by SABCC Al rights resended

$\begin{array}{llll}\text { PROPERTES } & \text { TYPICAL VALUES } & \text { UNITS } & \text { TEST METHOOS } \\ \text { at } 10 \mathrm{~N} \text { [STI/A] } & 150 & \text { "C } & 150306 \\ \text { at } 50 \mathrm{~N} \text { (NST/B) } & 80 & \text { "C } & 150306\end{array}$

1) Gpeed of testhes: $50 \mathrm{~mm} / \mathrm{minh}$

(2) Spesed of trathin: 1 mmimin

(3) Flat wibe tenthar $30^{\circ} 10^{2} 4 \operatorname{mrm}$

(4) Temperaure ise $120 \% \mathrm{Cl}$

QUALITY

SABIC Europe is fully certified in accordance with the internstionally accepted quality standard ISO9001.

STORAGE AND HANDLING

Awoid prolonged storage in open sunlight, high temperstures $\left(<50^{\circ} \mathrm{C}\right)$ and / or hight humidity sa this could well speed up alteration and consequently lass

of quality of the material and /or its packaging. Keep material completely dry for good processing.

\section{DISCLAIMER}

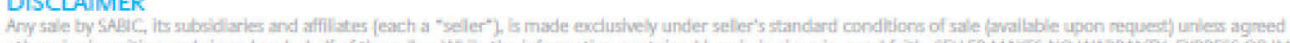

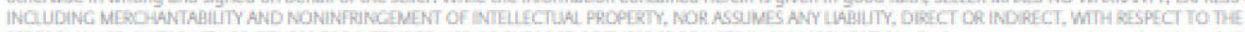

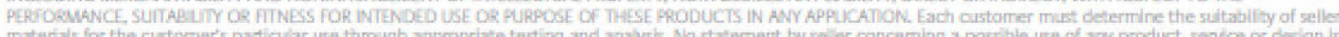
intended, or should be constnzed, to grant: any licerse under any patent or other intelectual property right. 


\section{سابك salvic}

\section{SABIC ${ }^{\circledR}$ HDPE B5823}

\section{HICH DENSITY POLYETHYLENE}

\section{DESCRIPTION}

SABIC HDPE B5823 is typically used for blow maulding of consumer packaging up to $5 \mathrm{l}$, cambining high stiffiness and a good ESCR level. This grade is typically used for psickaging the majority of household and industrial chemicals, such as detergents, cleaners, shampoos and casmetics, as weil as food packaging.

This product is not intended for and must not be used in any pharmaceutical/medical applications.

TYPICAL PROPERTY VALUES

Pmedian 2019050
PROPERTIES
TYPICAL VALUES
UNITS
TEST METHODS

POLYMER PROFERTIES

\section{Met. Flow Rate}

at. $190{ }^{2} \mathrm{C}$ and 216 ig

at $190^{\circ} \mathrm{C}$ and $5 \mathrm{~kg}$

a.16

at $190^{\circ} \mathrm{C}$ and $21.6 \mathrm{~kg}$

Denaty ${ }^{[1]}$

a.s9

23

958

1501133

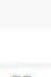

stress at break: 22

$\begin{array}{ll}\text { stres at breai: } & 22 \\ \text { strain at break: } & 1000\end{array}$

tensile modulus 115

Flexural test

Foran modules

Fieural strength

1150

1400

lrod impact notched

at $23{ }^{\circ} \mathrm{C}$

at $30^{\circ} \mathrm{C}$

Hardiness shore D

ESCR (10n igepal CO-630), F50

THEFULL PROPERTIES

Heat deflection temperature

at $0.45 \mathrm{MPa}$ (HDT/B)
Vicat Soltening Temperature

Temperature

at $10 \mathrm{~N}$ [ST] [/M]

Dsc test

meting point

enthalpy change

28
22
11500
1150

29

a 1505277

M72 $\quad 1505272$

Mh 150178

No2 150178

$12 \quad \mathrm{~b} / \mathrm{m}^{2} \quad 150150 / \mathrm{M}$

6. bj/m² $190180 / \mathrm{A}$

63

45 h ASTM DIE93:

(1) Comprexbe mealding of tex specimen acosdiry to $1501872-2$

(2) Speed of tusthy: $50 \mathrm{~mm} / \mathrm{min}$

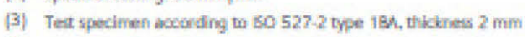

(4) Conditianing of trat specimert trmp. 23 " $\mathrm{C}$, nlative humblity $50 \mathrm{k}, 24$ houn

o 2019 Copyright by SABiC. All rigte resentod

CHEMISTRY THAT MATTERS 


\section{Appendix $\mathrm{F}$}

\section{List of interview questions (in Dutch) as used for interviews with plastic recycling industry (task 1)}

Doel van het gesprek is om een actueel overzicht te krijgen van de huidige afzetmarkten van PE- en PP recyclaat. De gegevens zullen geanonimiseerd en geaggregeerd worden gerapporteerd, zodat de informatie niet te herleiden is tot individuele bedrijven.

De volgende punten zullen ter sprake komen:

Input

- Wat zijn jullie grondstoffen? Is het alleen sorteerproducten DKR 329 PE of DKR 324 PP of mengen jullie ook post-industrieel kunststof of andere grondstoffen in?

- Uit welke landen / systemen verkrijgen jullie je grondstoffen?

- Wat is jullie oordeel over de kwaliteit van de huidige input?

- Hoe wordt de kwaliteit van de input vastgesteld?

- Welke stoorstoffen zijn voor jullie het meest kritisch?

- Kun je een indicatie geven van de yield?

- Zien jullie trends en ontwikkelingen in de input? (bijvoorbeeld ten aanzien van bepaalde stoorstoffen, zwart, overige, etc.?)

- Wat zullen wat jullie betreft de gevolgen c.q. ontwikkelingen zijn indien het meetpunt recycling wordt verlegd?

Type producten

- Welk type producten van harde PE en PP worden geproduceerd en afgezet? (Bijvoorbeeld gewassen maalgoed, regranulaat of compound)

- Welke eisen worden gesteld aan het materiaal? (Bijvoorbeeld MFI, treksterkte, DSC, etc.?)

- Wordt er bijgemengd met virgin kunststof of met andere additieven (kleurstof, carbon black)?

\section{Afzetmarkt}

- Wat is de huidige afzetmix (volumeverdeling naar markten/producten)?

- Hoe zien jullie dit in de toekomst ontwikkelen?

- Wat zijn typische vragen van klanten die nog moeten worden ingevuld? (bijv. foodsafety?)

- Wat is jullie opinie over de standaardisatie van recyclaat?

\section{Capaciteit}

- Wat is de huidige recyclingcapaciteit, en is deze gevuld?

- Beschikken jullie over certificaten? Zo ja welke?

- Wat is jullie toekomstbeeld qua recycling capaciteit? Zijn er belangrijke investeringen gepland? 
Doel van het gesprek is om een overzicht te krijgen van de gewenste inzet van recyclaat voor PE en PP bevattende verpakkingen. We focussen hierbij op primaire en secundaire verpakkingen. Doel is om na te gaan in welke verpakkingen en verpakkingscomponenten welke grades PE en PP worden toegepast en wat de toekomstwensen hiervoor zijn. De data zal anoniem per toepassing worden gerapporteerd.

De volgende punten zullen ter sprake komen:

\section{Huidige situatie}

- In welke (primaire en secundaire) verpakkingen (of componenten) gebruiken jullie momenteel gerecycled PE of PP?

- Waarom gebruiken jullie rPE/rPP?

- Over hoeveel volume hebben we het?

- Waar wordt dit materiaal ingekocht en door wie (lokaal, landelijk of global)?

- Wat zou jullie potentiele behoefte zijn? (als bedrijf, sector?)

- Is er voldoende aanbod van rPE en rPP granulaat?

- Is de kwaliteit van het huidige aanbod van rPE en rPP granulaat geschikt voor jullie toepassing?

- Welke "waarde" heeft het inzetten van recycled content? Bijvoorbeeld marketing, doelstelling, etc.

- Zien jullie trends/ontwikkelingen in het aanbod van gerecycled PE en PP? Is standaardisatie een hulpmiddel c.q. oplossing voor meer aanbod van recyclaat?

\section{Eisen/wensen}

- Is er een minimaal volume van rPE of rPP nodig voor een startproduct?

- Willen jullie puur rPE/rPP gebruiken of een mix/blend met virgin materiaal?

- Welke eisen stellen jullie in het algemeen aan rPE of rPP. Denk hierbij aan kleur, geur, etc. En door wie worden deze eisen geformuleerd?

- Zijn er ook toepassingskritieke eigenschappen? Bijv. MFI, treksterkte per toepassing.

- Welke verwerkingstechnologie wordt toegepast om de verpakking of verpakkingscomponent te maken? Bijvoorbeeld film blazen of casten, flessen blazen, plaat \& profiel extrusie, tape extrusie, spuitgieten, etc.

- Zijn er logistieke/organisatorische eisen? Bijv. voorraadbeheer, specifieke leverancier, etc.

- Zijn er eisen qua (maximale) kosten?

- Zijn er andere eisen?

\section{Toekomstperspectief}

- In welke verpakkingen zouden jullie graag recyclaat willen gebruiken maar kan dat momenteel nog niet? (bijv. foodsafety?, transparant rPP?)

- Hoe zien jullie de inzet van recyclaat in de toekomst? (<5 jaar) Verhouding virgin vs recyclaat,

- Welk type/kwaliteit rPE/rPP zouden jullie idealiter ter beschikking hebben?

- Welke volumes zijn gewenst? (bedrijfsniveau, markt?)

- Zien jullie verschuivingen binnen de verschillende kunststof materiaalstromen bv. van PP naar PET? Maar ook van bv. glas naar PET of PE/PP?

- Welke (kunststof) materiaalstromen zullen wat jullie betreft uitfaseren in verpakkingen? 


\section{Appendix G}

Complementary TGA data from commercially available pellet materials. Red curve indicates weight decrease in $\%$ from 0 to $100 \%$ vs temperature increase from $30^{\circ} \mathrm{C}$ till $900^{\circ} \mathrm{C}$. Blue curve is the normalized heat in $\mathrm{W} / \mathrm{g}$ from 0 to $10 \mathrm{~W} / \mathrm{g}$.
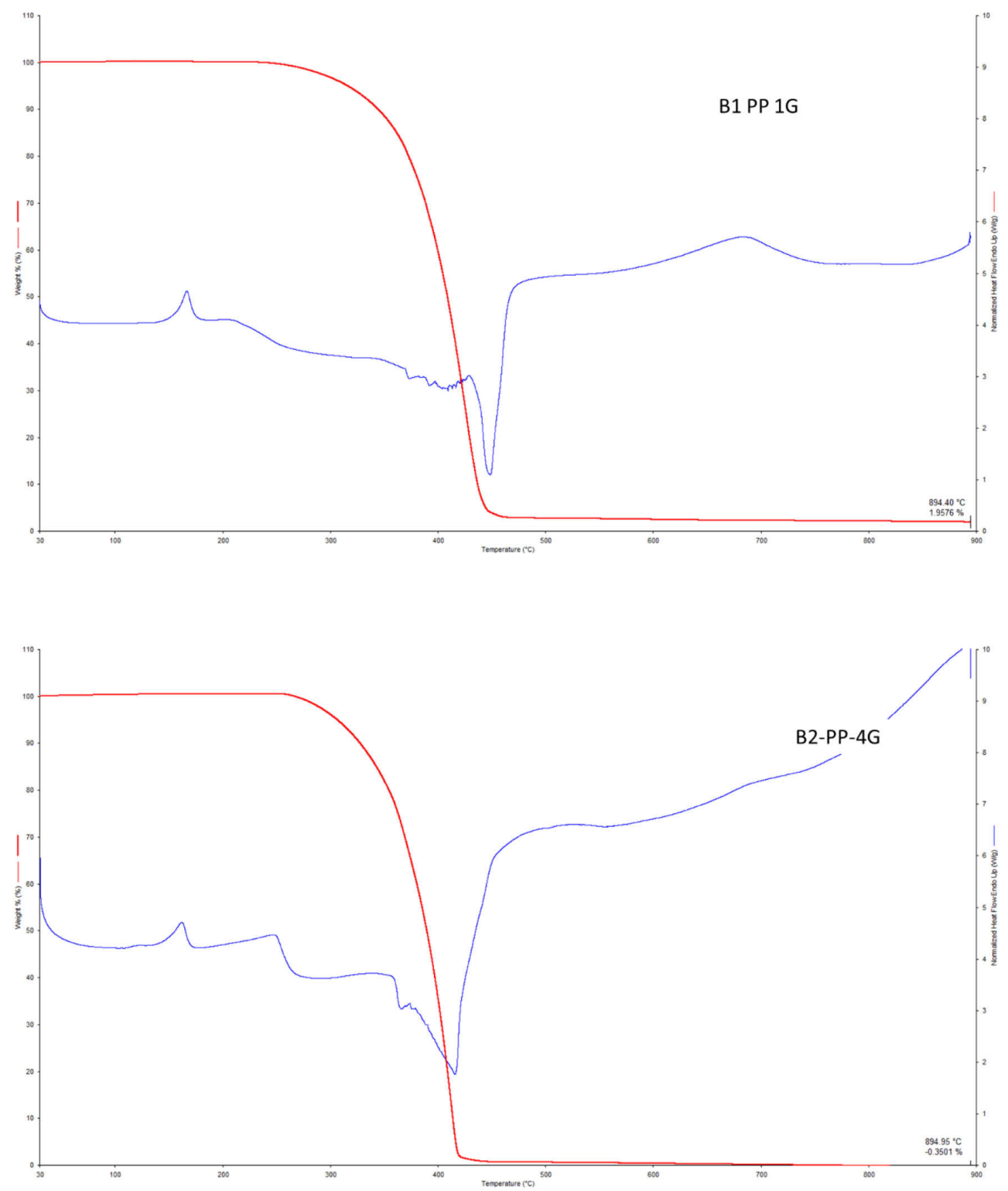

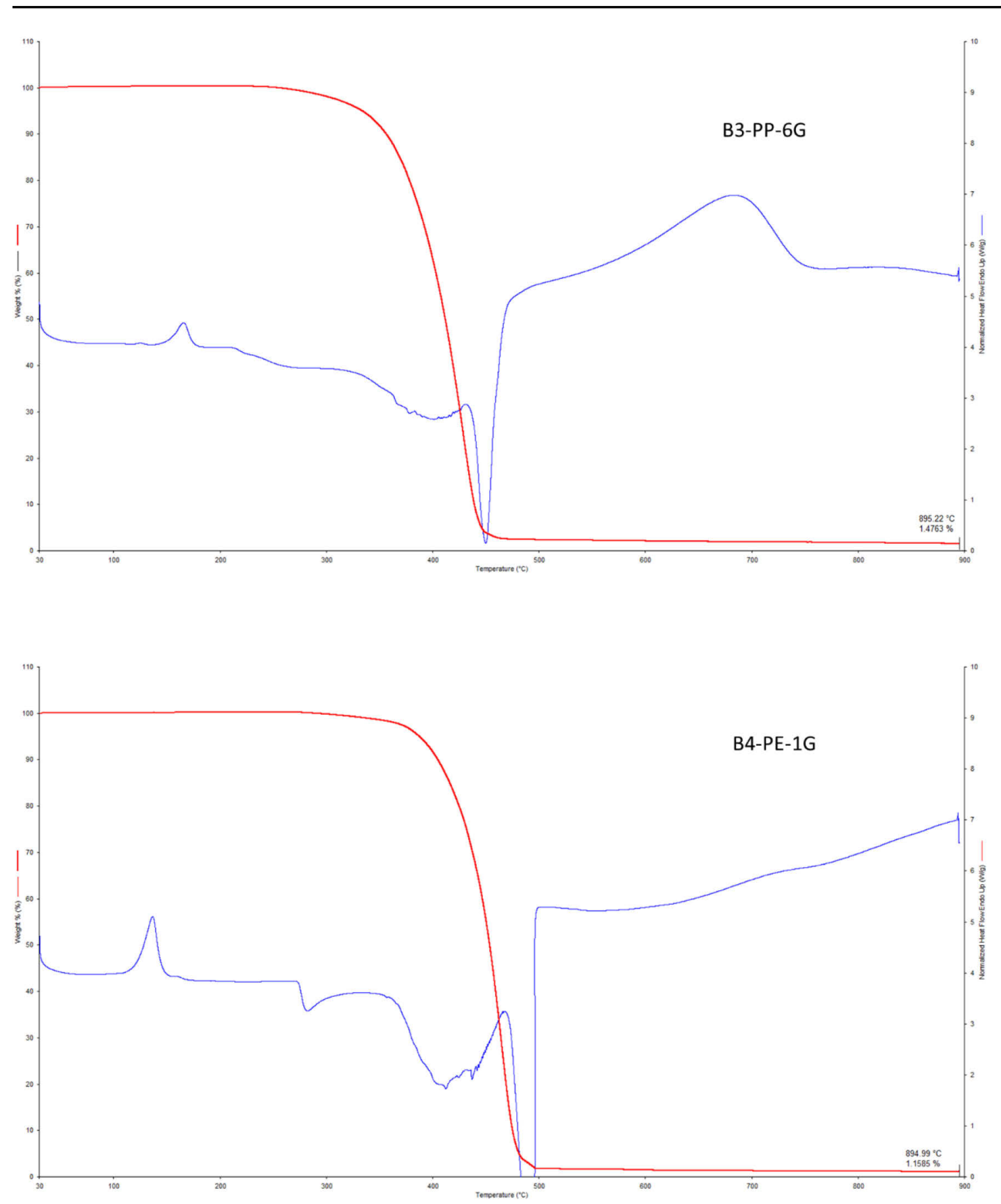




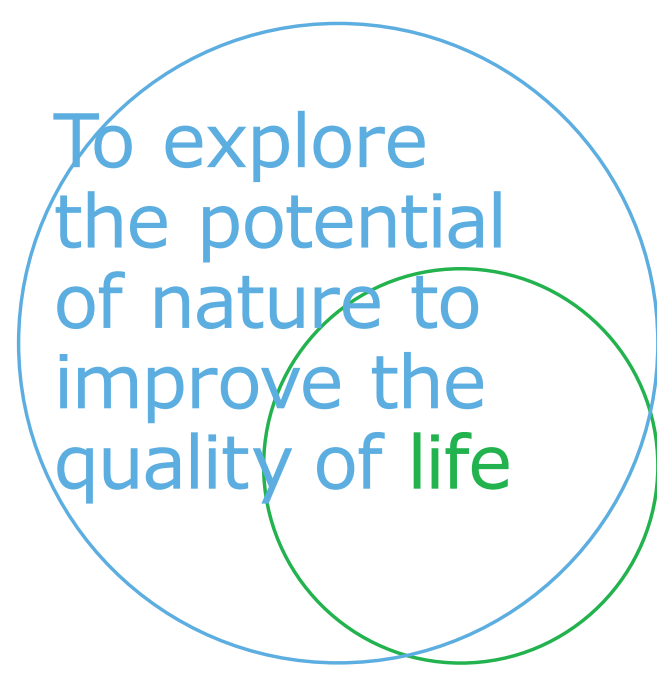

Wageningen Food \& Biobased Research Bornse Weilanden 9

6708 WG Wageningen

The Netherlands

www.wur.eu/wfbr

Einfo.wfbr@wur.nl

Report 2030

ISBN 978-94-6395-358-0

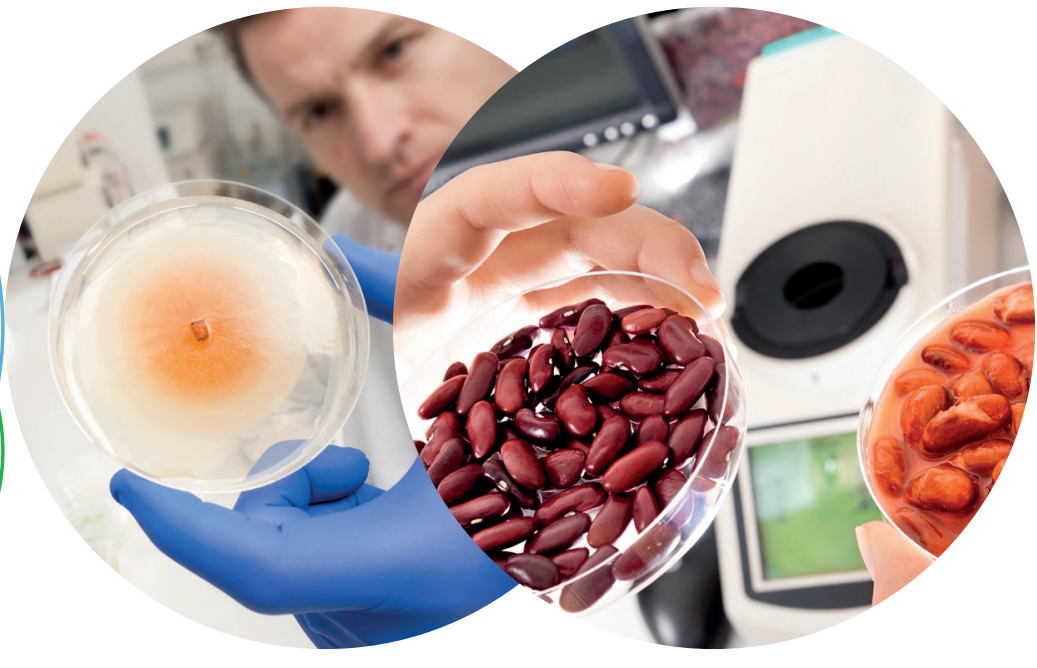

The mission of Wageningen University and Research is "To explore the potential of nature to improve the quality of life". Under the banner Wageningen University \& Research, Wageningen University and the specialised research institutes of the Wageningen Research Foundation have joined forces in contributing to finding solutions to important questions in the domain of healthy food and living environment. With its roughly 30 branches, 5,000 employees and 12,000 students, Wageningen University \& Research is one of the leading organisations in its domain. The unique Wageningen approach lies in its integrated approach to issues and the collaboration between different disciplines. 